\title{
Identificación y localización subcelular de proteasas asociadas a la senescencia foliar
}

\section{Martínez, Dana}

Doctor en Ciencias Naturales

Dirección: Guiamet, Juan José

Co-dirección: Bártoli, Carlos Guillermo

Facultad de Ciencias Naturales y Museo

2006

Acceso en:

http://naturalis.fcnym.unlp.edu.ar/id/20120126000046

\section{(c) (1) (2)(2) \\ BY NC SA}

Esta obra está bajo una Licencia Creative Commons

Atribución-NoComercial-Compartirlgual 4.0 Internacional

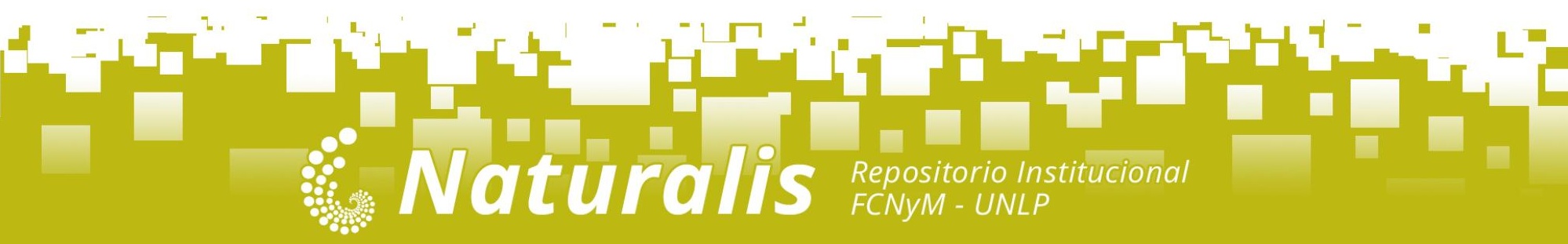




\section{INDICE GENERAL}

Indice general.........................................

Resumen.............................................ii

Abstract................................................iii

Indice de Figuras......................................iv

Indice de Tablas...........................................

Abreviaturas................................................

Capítulos $\quad$ Página

Capítulo 1 Introducción general.................................................

Capítulo 2 Análisis de la actividad de proteasas asociada a la senescencia foliar de trigo. Tipos mecanísticos y detección subcelular in vitro.................26

Capítulo 3 Localización de actividad proteolítica in vivo e identificación de compartimientos líticos asociados a la senescencia foliar de Arabidopsis y tabaco

Capítulo 4 Identificación y análisis funcional de una proteasa con actividad asociada a la senescencia foliar de Arabidopsis thaliana .83

Capítulo 5. Discusión General. 116

Bibliografía. 


\section{RESUMEN}

La senescencia foliar es el proceso del desarrollo previo a la muerte en el que la hoja se autodesmantela y libera sus componentes, v.g., nitrógeno, fósforo, posibilitando la reutilización de estos nutrientes por otras partes de la planta. A nivel celular, este proceso causa la degeneración total de los cloroplastos, donde reside la mayor parte de las proteínas foliares. El mecanismo de degradación del cloroplasto, y del resto de la maquinaria celular durante la senescencia es desconocido. El objetivo general de esta tesis fue estudiar la actividad proteolítica involucrada en la degradación masiva de proteínas foliares durante la senescencia. Se investigaron las características de la actividad de las proteasas implicadas y su ubicación subcelular, y se examinó en que compartimientos celulares tiene lugar la proteólisis. Se examinó la hipótesis de que en la degradación de proteínas cloroplásticas participan proteasas extraplastidiales, y que al menos parte de la proteólisis ocurre en otros compartimientos además del cloroplasto.

En experimentos in vitro, se detectó un grupo de proteasas cisteínicas que está presente en las hojas no senescentes en forma inactiva, y cuya actividad es dependiente del $\mathrm{pH}$ y característica de la senescencia foliar de trigo, "natural" o monocárpica, o inducida por incubación en oscuridad o déficit hídrico.

Utilizando microscopía confocal, se examinó in vivo la localización subcelular de la actividad proteolítica asociada a la senescencia foliar, la ubicación de la proteasa cisteínica específica de la senescencia SAG12, y la posible exportación a otras organelas de componentes cloroplásticos en células senescentes. Para este estudio se utilizaron marcadores de compartimientos ácidos y sustratos fluorescentes de proteasas, y como plantas modelo se analizaron líneas de Arabidopsis y tabaco salvajes y líneas que expresan SAG12-GFP o GFP direccionada al cloroplasto (CP-GFP). En este estudio se detectaron pequeñas $(\cong 1 \mu \mathrm{m})$ vacuolas asociadas a la senescencia (VAS), hasta el momento desconocidas. Las VAS concentran la mayor actividad proteolítica de tipo cisteínica y serínica de la célula fotosintética de hojas senescentes. En líneas de Arabidopsis que expresan SAG12-GFP, se observó que esta proteasa se localiza exclusivamente en las VAS. Una proporción de VAS contiene componentes provenientes del cloroplasto (i.e., clorofila), mientras que durante la senescencia foliar de la línea CP-GFP, la señal de GFP es también detectada en las VAS.

Los resultados obtenidos corroboran la hipótesis de que durante la senescencia foliar la degradación masiva de proteínas, en su mayoría cloroplásticas, es llevada a cabo, al menos parcialmente, por proteasas extraplastidiales, y que este proceso involucra otros compartimientos celulares (por ejemplo, las VAS descriptas aquí) además del cloroplasto.

Finalmente, se aplicó un enfoque proteómico, apoyado en el uso de espectrometría de masas, para la identificación de proteasas cuya actividad aumenta durante la senescencia foliar de Arabidopsis. Se identificó una proteasa de tipo subtilisina, cuya actividad aumenta marcadamente durante la senescencia, y se concentra en el apoplasto. El fenotipo de plantas mutantes donde la expresión de la subtilisina identificada está inactivada, indica que esta proteasa tiene un rol específico vinculado al desarrollo reproductivo, con efectos aparentemente indirectos en el progreso de la senescencia foliar individual

Los resultados obtenidos en este trabajo aportan una evidencia sólida sobre la existencia de un mecanismo de degradación de proteínas, específico de la senescencia de células fotosintéticas, y que involucra a las VAS descriptas. Por otra parte, durante la senescencia foliar también tiene lugar el aumento de actividad proteolítica que está involucrada en otros procesos del desarrollo, distintos de la degradación masiva de componentes cloroplásticos. 
Palabras clave: actividad proteolítica, degradación del cloroplasto, proteasas, senescencia foliar, vacuolas . 


\begin{abstract}
Senescence is a developmental process, in which the leaf dismantles itself and releases nutrients, e.g., nitrogen and phosphorous, that are recycled to other parts of the plant (e.g., growing seeds). At the cellular level, the most conspicuous process during senescence is degradation of chloroplasts, the organelles where most of the leaf protein resides. The mechanism by which chloroplasts and the rest of the cell organelles are degraded is unknown. The main objective of this Thesis was to study the proteolytic activity involved in protein degradation during senescence. The hyphotesis tested was that extraplastidial proteases participate in chloroplast protein degradation, and that at least part of this takes place in compartments other than chloroplasts. I studied the characteristics of the protease activity involved and its subcellular localization, and I examined in vivo the compartments with most of the proteolytic activity of senescing leaf cells.

A group of senescence-associated cysteine proteases were detected in vitro in experiments with senescing leaves of wheat. These proteases are present, but not active, in non senescent leaves, their activity is $\mathrm{pH}$ dependent and is specific of senescing leaves, either during "natural" monocarpic senescence, or senescence induced by protracted darkness or drought.

I examined the subcellular distribution of senescence associated protease activity, in vivo by confocal fluorescence microscopy. Small, senescence associated structures $(\cong 1 \mu \mathrm{m})$ of vacuolar nature (SAV) were labeled by markers of lytic organelles and fluorescent protease substrates. SAVs had not been reported before. SAVs concentrate most of the cysteine and serine protease activity of photosynthetic senescing cells. In Arabidopsis lines expressing SAG12-GFP, this senescence-specific protease was only detected in SAVs. A proportion of SAVs contains chloroplastic components (i.e., chlorophyll), and, in senescing leaves of the tobacco CP-GFP line (where GFP is fused to a transit peptide and targeted to the chloroplast), the GFP signal is detected in chloroplasts and VAS of senescing cells. These results lend support to the hyphotesis that extraplastidial proteases are involved in massive protein degradation, and that compartments (e.g., SAVs) other than chloroplasts are involved in degradation of photosynthetic components.

Finally, a proteomic approach was used to identify proteases whose activity increases during Arabidopsis leaf senescence. Using this methodology, I identified a subtilisin protease with senescence-associated activity. This protease is located in the apoplast, as its activity is detected in the apoplast of senescing leaves. The phenotype of mutants plants, where expression of this subtilisin is suppressed, shows that this subtilisin protease might have a specific rol regulating reproductive development, with possibly indirect effects on leaf senescence.

The results of this work show the existence operation of a specific pathway involved in degradation of photosynthetic cell proteins during senescence. In addition to massive degradation of proteins, other proteolytic activities with more specific regulatory functions (e.g., limiting inflorescence development) also increase during senescence.
\end{abstract}

Key words: chloroplast degradation, leaf senescence, proteases, proteolytic activity. 


\section{INDICE DE FIGURAS}

Página

Fig. 1.1 Rutas y compartimientos conocidos e hipotéticos de la ruta de degradación de clorofila. Los signos de interrogación indican pasos hipotéticos. Tomado de Takamiya et al. (2000)

Fig. 1.2 Modelo que ilustra las distintas vías inductoras de la senescencia, su superposición, y convergencia. Tomado de Buchanan-Wollaston et al. (2005)

Fig. 2.1. Estructura molecular del inhibidor de proteasas cisteínicas E64 y su derivado biotililado, DCG-04 (tomado de Greenbaum, et. al. (2000)

Fig. 2.2 Diagrama esquemático de la marcación de proteasas cisteínicas con DCG-04. Modificado de van der Hoon et al., (2004)

Fig. 2.3. La actividad de proteasas cisteínicas aumenta durante la senescencia de trigo.

Fig 2.4 Actividad en gel (zimograma) de proteasas asociadas a la senescencia foliar.

Fig. 2.5 Efecto del pH sobre la actividad in vitro de proteasas asociadas a la senescencia foliar.

Fig. 2.6. Efecto de inhibidores específicos de proteasas sobre la actividad proteolítica en zimogramas a $\mathrm{pH} 4.0$ (a) y $\mathrm{pH} 5.0$ (b). 
Fig. 2.7. Protoplastos (a), y fracción vacuolar (b) de hojas senescentes de trigo.

Fig. 2.8 Inmunodetección de SAG2 (a) y V-ATPasa SAG2 (b).

Fig. 2.9. Las proteasas cisteínicas asociadas a la senescencia se concentran en vacuolas. Se comparó la marca de DCG-04 en iguales cantidades de proteína (medidas por densitometría), de fracciones vacuolares (Vac), y de extractos totales de hojas (Ext).

Fig. 2.10. Disminución del contenido de clorofila durante la senescencia en oscuridad (a), monocárpica (b), y por déficit hídrico (c). Los valores son porcentajes del valor de clorofila inicial, registrado el primer dia de oscuridad, antesis, o déficit hídrico.

Fig. 2.11 Contenido de proteínas totales a lo largo de la senescencia foliar en las distintas situaciones analizadas. El material analizado corresponde al utilizado para las mediciones de clorofila. $\mathrm{C}=$ plantas control, $\mathrm{E}=$ plantas estresadas

Fig. 2.12. Zimograma de los distintos tratamientos inductores de la senescencia. La incubación se realizó a $\mathrm{pH}$ 4.0. $\mathrm{C}=$ plantas control, $\mathrm{E}=$ plantas estrasadas. Se analizó la actividad de proteasas de las muestras de la Fig. 2. 6.

Fig. 3.1. La actividad de proteasas cisteínicas de hojas senescentes se concentra en pequeñas vacuolas asociadas a la senescencia (VAS) 
Fig. 3.2 Localización de SAG12-GFP en células del mesófilo de hojas senescentes de Arabidopsis.

Fig. 3. 3 Distribución de las vacuolas asociadas a la senescencia (VAS) en hojas senescentes de Arabidopsis

Fig. 3.4. Expresión de CP-GFP en hojas no senescentes de tabaco

Fig. 3.5. Expresión de CP-GFP durante el progreso de la senescencia foliar

Fig. 3.6 Pequeñas vacuolas asociadas a la senescencia foliar (VAS) se observan en células fotosintéticas de tabaco

Fig. 3.7 Las vacuolas asociadas a la senescencia foliar tabaco concentran la mayor actividad proteolítica de la célula

Fig. 3.8. Localización de clorofila, GFP y VAS en hojas senescentes de plantas de tabaco de la línea CPGFP.

Fig. 3.9 Espectros de emisión de fluorescencia en las bandas correspondientes a GFP y clorofila en cloroplastos y VAS de plantas de tabaco con expresión de $\mathrm{CP}$ GFP

Fig. 3.10. Durante el progreso acelerado de la senescencia se observa un incremento del número de VAS.................................................... 
Fig. 4.1. Morfología de Arabidopsis en la etapa reproductiva de desarrollo. Esquema de la planta utilizado como referencia en el análisis morfológico (modificado de Mündermann et al., 2005).

Fig. 4.2 Actividad de proteasas asociada a la senescencia foliar de Arabidopsis.

Fig. 4.3 Las bandas de actividad asociada a la senescencia $\begin{array}{llll}\text { pueden } & \text { resolverse } & \text { geles }\end{array}$ bidimensionales

Fig 4.4 Identificación de una de las bandas analizadas.

Fig 4.5 La actividad de las isoformas de at3g14067 se concentra en al apoplasto de hojas senescentes.

Fig 4.6. Selección de plantas mutantes homocigotas para el gen At3g14067. Actividad proteolítica de las plantas seleccionadas

Fig. 4.7 Caída de clorofila foliar en plantas mutantes para At3g14067 (a) Hojas de la posición novena de la roseta, (b) hojas caulinares, de la posición quinta en el tallo principal.

Fig. 4.8. Senescencia de hojas cortadas inducida por oscuridad en de plantas mutantes para At3g14067. Se utilizaron hojas de la posición quinta apical de plantas en estado vegetativo. WT= genotipo salvaje, $\mathrm{KO}=$ genotipo mutante 
Fig. 4.9 Fenotipo producto de la mutación de At3g14067. Las fotos muestran las mismas plantas, de genotipos mutante $\mathrm{y}$ salvaje, a los 3 días (a) y 21 días después de la aparición del tallo floral principal (b). $\mathrm{WT}=$ planta salvaje $\mathrm{KO}=$ planta mutante (línea SALK147962).

Fig. 4.10. Número total de ramificaciones producidas por planta, en los genotipos mutante y silvestre. Los valores representan el promedio de 8 plantas....

Fig. 4.11. Desarrollo temporal de ramificaciones en plantas silvestres y mutantes para el gen At3g14067. Los valores $\begin{array}{lllll}\text { representan el de } & \text { promedio }\end{array}$

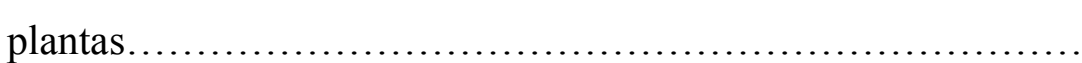




\section{INDICE DE TABLAS}

Página

Tabla. 1.1 Principales categorías funcionales de los genes asociados a la senescencia. Modificado de Gepstein et al. (2004) y Buchanan-Wollaston et al. (2005). ................................

Tabla 1.2 Proteasas y/o actividades proteolíticas representativas de la senescencia.

Tabla 2.1. Composición de buffers para analizar el efecto del $\mathrm{pH}$ sobre la actividad proteolítica.

Tabla 2.2. Características y concentraciones de los inhibidores de proteasas utilizados

Tabla 3.1. Cantidad y composición de VAS en hojas sometidas a tratamientos que alteraron el ritmo de la senescencia. Se representan valores promedio por célula.....................................................

Tabla 4.1. Características fenotípicas de dos líneas mutantes SADI. Las diferencias presentadas son similares a las observadas entre distintos experimentos realizados con una misma línea.

Tabla 4.2 Plasticidad de las plantas mutantes $S A D I$ en respuesta a variaciones en la cantidad de irradiancia. En esta tabla se comparan el fenotipo de plantas salvajes y mutantes (SALK147962) creciendo a alta y baja irradiancia, 50 y $180 \mu$ moles $\mathrm{m}^{-2} \mathrm{~s}-1$, respectivamente 


\section{ABREVIATURAS}

cDNA

CP-GFP

DTT

ESI-MS/MS

EST

FEC

$\mathrm{Fv}^{\prime} / \mathrm{Fm}^{\prime}$

GFP

IEF

$\mathrm{kDa}$

$\mathrm{KO}$

MALDI-TOF

NS

$\mathrm{pI}$

PPFD

ppm

PVPP

RE

S

SAG
Copy DNA (ADN copia)

GFP direccionada a cloroplasto

Ditiotreitol

Electrospray ionization- Tamdem mass spectrometry (Ionización por electroespray- seguido de espectrometría de masas en tamdem.)

Expressed sequence tag (Secuencia expresada)

Fluído extracelular

Fluorescencia variable/Fluorescencia máxima de la clorofila

Green fluorescent protein (proteína verde fluorescente)

Isoelectroenfoque

Kilodalton

"Knock out"

Matrix assisted laser deonization ionization- Time of flight (Espectrometría de masas mediante una matriz ionizableTiempo de vuelo)

No senescente

punto isoeléctrico

Photosynthetic Photon Flux Density (Densidad de flujo fotónico fotosintético)

partes por millón

Polivinil polipirrolidona

Retículo Endoplásmico.

Senescente

senescente-associated gene (Gen asociado a la senescencia) 
CAPITULO 1

Introducción General 


\section{INTRODUCCIÓN}

Nada se pierde, todo se transforma (Lavoisier, 1789) es un principio aplicable a sucesos del desarrollo en apariencia netamente degenerativos, como el evidenciado a través del amarillamiento de las hojas debido a la pérdida de clorofila. Estos fenómenos son procesos de reciclado de materia, ya que la degradación controlada y ordenada de los constituyentes celulares (v.g., proteínas, ácidos nucleicos, lípidos) da lugar a la liberación de nutrientes, principalmente fósforo y nitrógeno $(\mathrm{N})$ y a su redistribución hacia distintas partes del organismo i.e., hojas en crecimiento, frutos en desarrollo (Hörtesnsteiner y Feller, 2002; Masclaux et al., 2000). Los ejemplos mencionados representan los casos más característicos de senescencia. La senescencia foliar en particular está estrechamente asociada a la caída de la actividad fotosintética, debido a la degradación de la maquinaria cloroplástica (Matile 2001), y su ocurrencia tiene grandes implicancias económicas y ecológicas. El momento de inicio y la manera en que progresa la senescencia repercuten en el rendimiento en la mayoría de los cultivos. La senescencia prematura limita la duración del período fotosintético, que según el momento del ciclo se traduce en la disminución del número y/o del tamaño de los granos (Borrell et al., 2000). En sistemas forestales, una demora de 5 a 10 días en la senescencia del canopeo de un bosque decíduo produce un aumento de su productividad de alrededor de $500 \mathrm{~kg} \mathrm{C} \mathrm{ha}^{-1}$ anuales (Goulden et al., 1996). La calidad y el valor en el mercado de distintos productos vegetales, i.e., verduras, frutos, flores, están sujetos en gran medida a los efectos de la senescencia poscosecha, que según los casos se evidencia en la clorosis, ablandamiento, o el mal olor debido a la liberación de amonio (Pogson y Morris, 2004; Baclayon et al., 2004). Por otra parte, en ambientes con sequía moderada, la senescencia puede acelerar la redistribución de los fotosintatos producidos, favoreciendo el rendimiento (Edmeades et al., 1999).

La senescencia tiene lugar a través de la ejecución de un programa de expresión génica (Lohman et al., 1994; Buchanan-Wollaston 1997; Yoshida 2003), aunque su ocurrencia es función de la combinación de diversos factores endógenos y 
ambientales (v.g., edad, balance hormonal, condiciones lumínicas, estreses bióticos y abióticos, Oh et al., 1996; Weaver et al., 1998; Noodén y Penney 2001). La relevancia de los distintos factores es variable, e incluso relativa, dependiendo del tipo de aproximación y la escala de análisis utilizada, que va desde el nivel molecular al de comunidad (Lohman et al., 1994; Hikosaka 2005).

\section{1- El síndrome de la senescencia}

La senescencia ha sido definida como una etapa del desarrollo normal, cuyo rasgo principal es la degradación masiva de macromoléculas, a través de un proceso organizado y que conduce a la muerte de células, órganos, o de la planta entera (Noodén 1988; Thomas et al., 2003). La amplitud de este concepto se debe en gran medida a que se desconoce el mecanismo bioquímico primario de la senescencia y no se ha podido distinguir entre los cambios fisiológicos y moleculares centrales, de aquellos que son secundarios o meramente la consecuencia del desarrollo de la senescencia. De la misma forma, resulta difícil discernir si los cambios asociados con el inicio de la senescencia (i.e., aumento o disminución de la expresión de un gen o la actividad de una enzima) son desencadenantes o son producto del proceso. Es por esto que la senescencia se considera un síndrome (Noodén 1988; Noodén et al., 2004). El síndrome de senescencia foliar está caracterizado por la disminución de la actividad fotosintética y la degradación de los componentes celulares comenzando en el cloroplasto, donde se concentra la mayor parte de las proteínas foliares, principal fuente de $\mathrm{N}$ exportable (los cambios particulares del cloroplasto asociados al síndrome son tratados en el punto 1.1.4 de este capítulo). La removilización de $\mathrm{N}$ foliar se pone de manifiesto a través de la caída del contenido de clorofila, el rasgo visible del síndrome y que representa la medida de senescencia más utilizada en los estudios en este campo (Matile 2001; Fang et al., 1998). De acuerdo a la serie de eventos que comprenden este síndrome, se distinguen tres fases: la fase inicial caracterizada por la disminución de actividad fotosintética y marcados cambios en la expresión génica; la fase degenerativa, de desmantelamiento de estructuras y degradación de macromoléculas, y la fase terminal, que conduce a la muerte celular (Noodén et al., 1997). El inicio de la senescencia estaría controlado principalmente a nivel de expresión génica, mientras que la fase degenerativa estaría sujeta a la 
regulación postraduccional de la actividad hidrolítica y al desarrollo de distintos procesos bioquímicos (Thomas et al., 2003). Dado que representa la etapa previa a la muerte, la senescencia foliar es considerada por algunos investigadores como un proceso de muerte celular programada $(\mathrm{PCD})$ que ocurre en forma más o menos sincronizada en las células de una hoja (Beers et al., 2000; van Doorn y Woltering, 2004). Sin embargo, el sindrome puede revertirse durante su fase inicial (KléberJanke y Krupinska, 1997; Zavaleta-Mancera, 1999), y es independiente y experimentalmente disociable de la muerte de la hoja (Wingler et al., 2005).

Mucho menos controvertida es la interpretación funcional sobre la senescencia foliar, como mecanismo de recuperación de nutrientes componentes de una hoja donde la capacidad fotosintética ha declinado (Gan y Amasino, 1997; Bleecker 1998; Matile 2001; Hörtensteiner y Feller, 2002).

\subsection{2- Tipos de senescencia}

La senescencia foliar tiene lugar de acuerdo a un patrón espacial y/o temporal en la planta, y en respuesta a condiciones ambientales desfavorables que afectan a hojas particulares o a todo el individuo. En todos los casos la edad de la hoja incide en la respuesta a la inducción de la senescencia.

La senescencia foliar secuencial comienza en las hojas más viejas y basales de la planta y se extiende en forma vertical hacia el ápice. Este tipo de senescencia se observa principalmente en plantas de crecimiento rápido y hábito monocárpico, como el trigo y los cereales en general, y la especie modelo Arabidosis thaliana (Stieger y Feller, 1994; Grbic y Bleecker, 1995).

El desarrollo reproductivo representa uno de los factores inductores de la senescencia más relevante (Hadfield y Bennett, 1997). En las especies monocárpicas la senescencia está sumamente ligada al evento reproductivo y conduce a la muerte del individuo (senescencia monocárpica, Noodén y Guiamét, 1989; Noodén y Penney, 2001). Este tipo de senescencia responde a un control de tipo correlativo, cuyo mecanismo se desconoce. Podría estar relacionado con la pérdida de la capacidad meristemática de las estructuras vegetativas (cese de crecimiento global) que acompaña el paso a la etapa reproductiva (Hensel et al., 1994; Bleecker y Patterson, 1997; Ratcliffe et al., 1998). Se ha sugerido la participación de una señal 
desencadenante de la senescencia que sería generada en las estructuras reproductivas, flores y frutos (Noodén 1988). Otra hipótesis es que la demanda de nutrientes ejercida por los órganos reproductivos en crecimiento desencadena la removilización de $\mathrm{N}$ foliar hasta causar la muerte del individuo por "agotamiento" (Hensel et al., 1994). Los resultados de experimentos manipulativos, de remoción de frutos y/o de alteración de la relación fuente (fotosíntesis foliar)/ destino (frutos/semillas) reflejan variabilidad de respuestas en las distintas especies. Por ejemplo, la remoción de frutos acelera la senescencia monocárpica de maíz (Christensen et al., 1981), y la retrasa en Arabidopsis (Noodén y Penney, 2001). Por otra parte, la senescencia monocárpica de plantas masculinas y plantas estériles indica que otros controles, además de los generados por los frutos, estarían implicados en este tipo de senescencia (Hensel et al., 1994; Noodén y Penney, 2001).

Los cambios estacionales de temperatura y fotoperíodo son los principales desencadenantes de la senescencia foliar en especies árboreas de hoja caduca (Lee et al., 2003). Un rasgo característico de muchas especies donde predomina la senescencia estacional es la producción de antocianos, de función fotoprotectora (Field et al., 2001), y que permitirían maximizar la reabsorción de N (Hoch et al., 2003). Mientras el nitrógeno foliar removilizado durante la senescencia monocárpica contribuye al desarrollo de frutos, el nitrógeno liberado durante la senescencia estacional es principalmente reutilizado en el desarrollo de nuevas hojas en la estación siguiente (Cooke y Weih, 2005).

\subsubsection{Factores que desencadenan o retrasan la senescencia}

\subsubsection{Factores ambientales}

Distintos tipos de estrés, v.g., presencia de patógenos, contaminantes, limitación de recursos, etc, desencadenan la senescencia. Entre las limitaciones más frecuentes, el déficit de $\mathrm{N}$ y el déficit hídrico son las de mayor impacto sobre la senescencia. La deficiencia de nitrógeno afecta el metabolismo limitando el crecimiento y la productividad vegetal (Martré et al., 2003). Alrededor del 75\% del $\mathrm{N}$ foliar se encuentra formando parte de las proteínas cloroplásticas (Hörtensteiner y Feller, 2002). Una baja disponibilidad de $\mathrm{N}$ se asocia con un bajo nivel de proteínas 
fotosínteticas, y con la disminución de la relación N/C. La acumulación de carbohidratos limita la síntesis de proteínas fotosínteticas y acelera la removilización de $\mathrm{N}$, desencadenando la senescencia foliar (Lawlor 2002). El balance N/C, o la acumulación relativa de carbohidratos podrían ser sensores de las condiciones fotosintéticas en las distintas partes de la planta, desencadenando la senescencia de hojas expuestas a condiciones lumínicas inadecuadas o sombreadas (Lawlor 2002). La acumulación de precursores de citocininas (hormonas que retrasan la senescencia) en las raíces y su traslocación a la parte aérea es dependiente de los niveles endógenos de N (Sakakibara 2003).

El déficit hídrico promueve la senescencia foliar. Durante este tipo de estrés la actividad fotosintética disminuye debido a limitaciones estomáticas y metabólicas (Cornic 2000). La fijación de $\mathrm{CO}_{2}$ se ve limitada por la disminución de la actividad y del contenido de Rubisco (Parry et al., 2002), cuya síntesis queda detenida a nivel traduccional (Kawaguchi et al., 2003). Los niveles de clorofila y de proteínas foliares disminuyen marcadamente en plantas de trigo sometidas a estrés hídrico (Martinez et al., 2003). El déficit hídrico provoca tanto la disminución de la síntesis de proteínas (Kawaguchi et al., 2003) como el aumento de la actividad proteolítica (Khanna Chopra et al., 1999). La inducción y el progreso de la senescencia dependen, entre otros factores, de la duración y severidad del estrés. Bajo situaciones de déficit hídrico moderado la senescencia se inicia prematuramente, aunque los cambios moleculares ligados al síndrome son similares a los que ocurren durante la senescencia con buena disponibilidad hídrica (Pic et al., 2002).

La interacción entre la disponibilidad de $\mathrm{N}$ y la disponibilidad de agua afecta diferencialmente el progreso de la senescencia. Suministros no limitantes de N y de agua retrasan la senescencia, mientras que una alta disponibilidad de $\mathrm{N}$ en combinación con un déficit hídrico moderado incrementa la removilización de $\mathrm{N}$ acelerando la senescencia foliar (Bänziger et al., 1999)

La irradiancia y la composición espectral de la luz tienen efecto sobre la senescencia foliar. Los cambios morfogénicos y metabólicos en respuesta a variaciones lumínicas usualmente se solapan. Con el incremento del número de hojas y del área foliar de una planta o cultivo las hojas de posiciones inferiores resultan sombreadas, quedando expuestas a una menor irradiancia y a luz de baja relación Rojo/Rojo lejano (R/FR). Este fenómeno se relaciona con la senescencia foliar secuencial, aunque se desconoce cual de los efectos, disminución de la actividad 
fotosintética o la disminución de la relación $\mathrm{R} / \mathrm{FR}$, tiene mayor incidencia sobre la inducción de la senescencia (Rousseaux et al., 1996).

La privación total de luz desencadena la senescencia de las hojas. El progreso de la senescencia en hojas escindidas de la planta se acelera si estas son colocadas en oscuridad (Weaver et al., 1998). El sombreado total de hojas adheridas a la planta también tiene un efecto promotor de la senescencia, aunque el grado de inducción que la oscuridad ejerce sobre el sindrome varía de acuerdo a la edad de la hoja, y depende de controles de tipo correlativo además de las condiciones metabólicas y hormonales de cada órgano. La imposición de oscuridad sobre la planta entera involucra además otro tipo de respuestas. En Arabidopsis se registró un efecto inhibitorio de la oscuridad sobre el desarrollo global del organismo, y una demora de la senescencia foliar individual (Weaver y Amasino, 2001). El mismo tratamiento acelera la senescencia en cebada (Kleber-Janke y Krupinska, 1997).

\subsubsection{Señales hormonales}

Las distintas hormonas participan en la regulación de la senescencia. Entre todas, las citocininas y el etileno son las hormonas más relevantes en la senescencia, retrasando y promoviendo su progreso, respectivamente.

El envejecimiento de las hojas y otros órganos es acompañado por la disminución de los niveles endógenos de citocininas (Noh et al., 2004). La aplicación de citocinina exógena retrasa la senescencia (Clarke et al., 1994; Weaver et al., 1998). Los efectos de las citocininas como reguladores negativos de la senescencia foliar han sido demostrados por Gan y Amasino (1995), alterando los niveles endógenos de la hormona a través de la construcción de un sistema de autorregulación en que la enzima isopentenil transferasa es expresada bajo un promotor específico de la senescencia.

El efecto más conocido del etileno es su participación en la maduración de frutos y en la promoción de la senescencia de flores y hojas (Jones et al., 1995; Weaver et al., 1998). En plantas donde se encuentra mutado el receptor de esta hormona la senescencia foliar se demora (Bleckeer et al., 1988). El aislamiento de distintos mutantes de la síntesis y percepción de etileno demuestran un rol promotor más que inductor de esta hormona sobre la senescencia (Grbic y Bleckeer, 1995; Ping et al., 2005). Entre otros efectos, la expresión asociada a la senescencia foliar de 
proteasas y de clorofilasa es inducida por etileno (Drake et al., 1996; Trebitsh et al., 1993). El etileno promueve la senescencia de hojas adheridas y escindidas de la planta, y su uso es un recurso frecuentemente utilizado para promover la senescencia en estudios sobre este proceso.

\subsubsection{Cambios subcelulares y degradación del cloroplasto durante la senescencia}

El carácter gradual de la senescencia foliar se evidencia también a nivel celular, a través del desmantelamiento ordenado y secuencial de sus constituyentes. La regulación molecular y bioquímica de la ejecución de este programa implica el mantenimiento de la integridad de varias organelas y de las funciones metabólicas y génicas hasta un estadio avanzado del proceso. El desarmado celular comienza y se concentra en los cloroplastos, donde está contenida la mayor parte del $\mathrm{N}$ y del $\mathrm{C}$ celular exportable. Una vez que los componentes cloroplásticos han sido removilizados el proceso se extiende al resto de la célula (Matile, 2001). Hacia el final de la senescencia tendrían lugar acontecimientos comunes a distintos tipos de PCD, como la rotura del tonoplasto, liberación de hidrolasas vacuolares, y degradación de ADN nuclear (Delorme et al., 2000). La separación temporal entre la degradación plastidial (etapa reversible de la senescencia) y la muerte celular permite la removilización eficiente de nutrientes y le confiere al proceso un alto grado de plasticidad de probable significancia adaptativa. En la mayor parte de las especies analizadas, el número de cloroplastos por célula permanece constante durante la senescencia (Matile, 2001), aunque se han registrado reducciones en algunos casos, como trigo (Warley et el., 1984) y tabaco (Zavaleta-Mancera et al., 1999). El/los mecanismo/s de degradación del cloroplasto durante la senescencia se desconoce/n. Distintas evidencias indican eventos de exportación intracelular de componentes cloroplásticos y/o de fragmentación del cloroplasto durante la senescencia. Por ejemplo, los catabolitos finales de clorofila se concentran en la vacuola central (Hinder et al., 1996). Durante la senescencia foliar de soja se observa la salida del cloroplasto de cuerpos osmiófilos, conteniendo clorofila (Guiamét et al., 1999). En hojas de trigo fijadas por criosustitución a alta presión se registraron estructuras de doble membrana, de alrededor de $1 \mu \mathrm{m}$ de diámetro, exclusivas de hojas senescentes, 
donde se inmunodetectan las proteínas cloroplásticas Rubisco y glutamina sintetasa, o sus fragmentos de degradación (Chiba et al., 2003).

\subsubsection{Diferenciación de cloroplasto a gerontoplasto.}

Estudios de microscopía electrónica revelan una trasformación estructural del cloroplasto a medida que avanza la senescencia, caracterizada por la desorganización y vesiculización de membranas, reducción del volumen estromático y aumento del número de plastoglóbulos, que en conjunto le dan a la organela un aspecto final de saco ocupado por cuerpos osmiófilos, denominado gerontoplasto (Matile, 2001). Durante esta transición las membranas tilacoidales se dilatan y deforman, dejan de distinguirse granas y algunos de sus componentes, principalmente triacilgliceroles y carotenoides, se acumulan en plastoglóbulos (Kaup et al., 2002). En forma paralela al desmantelamiento y degradación de los complejos tilacoidales tiene lugar la caída del contenido de proteínas solubles y de la actividad fotosintética, que disminuye principalmente debido a limitaciones en la actividad y cantidad de la enzima Rubisco. La síntesis de componentes fotosintéticos diminuye durante la senescencia, aunque su degradación masiva sería el factor principal de la degeneración del cloroplasto (Matile et al., 2001). La degradación y removilización de macromoléculas durante la transformación a gerontoplasto podría estar asociada a la exportación de clorofila y proteínas fotosintéticas y/o a la extrusión de pequeñas porciones del cloroplasto observadas recientemente (Chiba et al., 2003).

\subsubsection{Degradación de macromoléculas}

A continuación me refiero a la degradación de ácidos nucleicos, lípidos y pigmentos tilacoidales, y características generales sobre la degradación y disminución de algunas proteínas fotosintéticas. La proteólisis asociada a la senescencia es tratada en el punto 1.3 de este capítulo.

\section{Degradación de ácidos nucleicos}

El ADN cloroplástico (ctADN) es degradado al inicio de la senescencia, incluso antes de que se evidencien los primeros síntomas del proceso (Rowan et al., 2004; Sodmergen et al., 1991). Inada et al. (1998) detectan, por inmunofluorescencia, 
la presencia de fragmentos de ctADN en el cloroplasto y distribuídos en el citoplasma. La/s vía/s de degradación del ARN se desconocen. El ARN cloroplástico, como el mitocondrial y nuclear serían degradados por ARNasas inespecíficas (Green, 1993). La mayor parte de las ARNasas y las ADNasas, están contenidas en la vacuola central (Abel y Glund 1987; Lers et al. 1998). En distintos casos de PCD las nucleasas son activadas al ser liberadas tras la rotura del tonoplasto, como último paso antes de la muerte celular (Obara et al., 2001). Sin embargo, se han registrado incrementos de actividad nucleasa durante el transcurso de la senescencia, e incluso desde las etapas iniciales del proceso, sugiriendo otras vías de degradación. La actividad ARNasa y ADNasa se incrementa desde el comienzo de la senescencia foliar de perejil (Petroselinum crispum), desencadenada de forma natural, o inducida por oscuridad, y también en hojas jóvenes escindidas de la planta y tratadas con etileno (Canetti et al., 2002). La actividad ADNasa y ARNasa de la nucleasa bifuncional de Arabidopsis BFN1 aumenta durante la senescencia foliar (Perez-Amador et al., 2000). En general, la actividad nucleasa in vitro es dependiente del estado redox y es inhibida por agentes quelantes (Chen et al., 2004). El pH óptimo de actividad in vitro es variable, desde $\mathrm{pH}$ 5,0 a pH 9,0 (Blank y McKeon, 1991).

\section{Degradación de lípidos}

Las membranas tilacoidales contienen la mayor cantidad de los lípidos de la célula fotosintética. Están constituídas principalmente por galactolípidos, y cantidades menores de fosfolípidos y lípidos neutros (ácidos grasos libres, diacilgliceroles (DAG), y triacilgliceroles (TAG)) (Lee, 2000). La composición lipídica tilacoidal se modifica notoriamente conforme estas membranas son degradadas durante la senescencia. En Arabidopsis el contenido relativo de galactolípidos disminuye de $80 \%$ en hojas jóvenes a $53 \%$ en hojas senescentes, mientras que la concentración de TAG aumenta (Kaup et al., 2002). Los galactolípidos representan un precursor importante en la síntesis de novo de sacarosa, que es exportada vía floema durante la senescencia (Matile, 2001). El catabolismo de galactolípidos se correlaciona con el aumento de la actividad de $\beta$-galactosidasa, la aparición de glioxisomas y el aumento de enzimas de la $\beta$-oxidación en hojas senescentes (Bellis et al., 1990; Chrost y Krupinska, 2001). Por otra parte, los ácidos grasos provenientes de la desesterificación de los galactolípidos pueden ser utilizados 
en la síntesis de TAG, que es acumulado junto a carotenoides y ésteres de carotenoides en plastoglóbulos (Kaup et al., 2002).

Degradación de la clorofila y otros pigmentos

La degradación de clorofila no es relevante en términos de la liberación y reciclado de nutrientes, pero representa un mecanismo fotoprotector que evita la acumulación de moléculas fotodinámicas mientras las membranas tilacoidales, todavía fotoquímicamente activas, son desmanteladas durante la senescencia (Pružinská et al., 2005). Además de ser un mecanismo de detoxificación (Matile, 2001), la degradación de clorofila parece ser el paso previo y necesario para la degradación de las proteínas que la acomplejan, principalmente LHCII (Guiamét et al., 1991). La vía de degradación de la clorofila durante la senescencia presenta variaciones entre especies, aunque se ha establecido una vía catabólica principal y se han descrito las enzimas involucradas. La degradación de la clorofila ocurre en distintos compartimientos subcelulares. Se inicia en el cloroplasto con la remoción de la molécula de fitol y luego del $\mathrm{Mg}^{+2}$, reacciones catalizadas por las enzimas clorofilasa y magnesio dequelatasa respectivamente. El feofórbido resultante es clivado por la enzima feoforbido oxigenasa $(\mathrm{PaO})$, dando lugar al catabolito RCC ("red chlorophyll catabolite"); este es reducido a un catabolito todavía fluorescente (FCC), que luego de ser oxidado y desmetilado se acumula como tetrapirrol abierto no fluorescente (NCC) en la vacuola central (Hinder et al., 1996). La actividad de la mayoría de las enzimas involucradas en esta vía es constitutiva, a excepción de la $\mathrm{PaO}$, cuya actividad y expresión génica se incrementan marcadamente durante la senescencia (Pružinská et al., 2005; Buchanan-Wollaston et al., 2005). La actividad clorofilasa aumenta en respuesta a tratamientos con las hormonas etileno y jasmonato de metilo, que aceleran la senescencia (Trebitsh et al, 1993; Benedetti y Arruda, 2002). Uno de los aspectos menos conocidos de la degradación de clorofila es la ubicación subcelular donde cada reacción tiene lugar. Mientras que la clorofila se encuentra en los tilacoides, la enzima clorofilasa, junto a la $\mathrm{PaO}$, se localizan en la membrana interna (MI) del cloroplasto (Matile y Schellenberg, 1996). La ubicación de estas enzimas sugiere que la clorofila podría ser trasladada desde los tilacoides hacia la (MI) del cloroplasto para su degradación (Matile et al., 1999). Un candidato a realizar esta función es MBP-WSCP, una proteína hidrosoluble que en condiciones nativas remueve clorofila de tilacoides aislados (Satoh et al., 1998), aunque su 
función in vivo se desconoce. Los plastoglóbulos podrían operar como vehículo de la clorofila hacia la MI, aunque no hay evidencias claras que apoyen esta posibilidad. Por otra parte, en distintas especies incluyendo Arabidopsis se encuentran dos isoenzimas de clorofilasa, ambas activas en condiciones naturales, aunque solo una posee un péptido de tránsito a cloroplasto (Tsuchiya et al., 1999; Jacob-Wilk et al., 1999). La otra isoenzima sería transportada por la ruta de secreción a través de RE, mientras que su localización subcelular final y la manera en que tiene contacto con la clorofila se desconocen. Takamiya el al. (2000), sintetizan los aspectos establecidos y aquellos todavía desconocidos de la ruta de degradación de clorofila. La Fig. 1.1 muestra un diagrama de estos autores.

Fig.1.1 Rutas y compartimientos conocidos e hipotéticos de la ruta de degradación de clorofila. Los signos de interrogación indican pasos hipotéticos. Tomado de Takamiya et al., 2000.

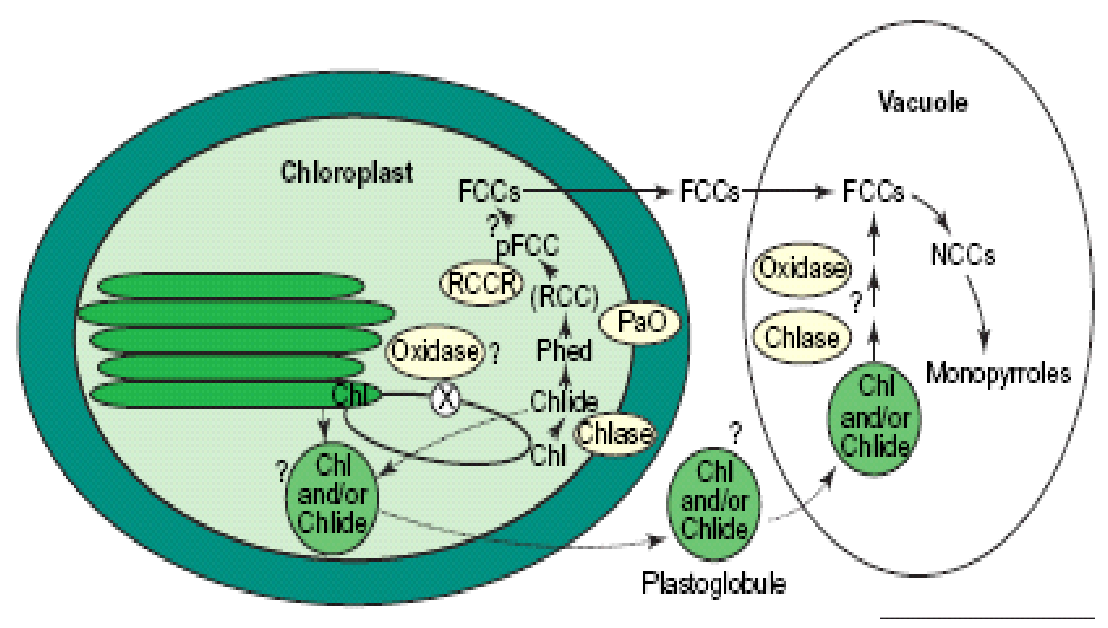

Chlase: clorofilasa, Chlide: clorofílido, FCCs: catabolitos fluorescentes de la clorofila, NCC: catabolito no fluorescente de la clorofila, $\mathrm{PaO}$ : feofórbido oxigenasa, $p F C C$ : catabolito primario fluorescente de la clorofila, Phed: feofórbido, RCC: catabolito rojo de la clorofila, RCCR: RCC reductasa, X: transportador hipotético de clorofila. 
Degradación de proteínas

Prácticamente se desconoce el mecanismo por el cual las distintas proteínas fotosintéticas son degradadas durante la senescencia. Los tilacoides contienen el $25 \%$ de las proteínas totales del cloroplasto (Evans 1988). La degradación de las proteínas tilacoidales ocurre en paralelo a la pérdida de galactolípidos y clorofila. Entre los complejos de proteínas tilacoidales, la degradación del citocromo b6/f ocurre antes que los fotosistemas I y II (PSI y PSII), y la ATP sintasa (Guiamét et al., 2002). Entre las proteínas estromáticas, Rubisco representa la mayor parte del $\mathrm{N}$ removilizable de la célula. Por medio de inmunodetección se han examinado cambios en los niveles estables de Rubisco durante la senescencia y la acumulación de distintos fragmentos producto de su hidrólisis parcial. Los patrones obtenidos son variables según las especies y las condiciones experimentales. Cloroplastos de hojas senescentes de arveja (Pisum sativum L.) acumulan un fragmento de degradación de Rubisco de 36 kDa (Bushnell et al., 1993), mientras que en cloroplastos aislados de hojas senescentes de trigo (Triticum aestivum L.) se acumula un fragmento de degradación parcial de la subunidad grande de Rubisco (LS) de 44 kDa (Kokubun et al., 2002). La señal de inmunodetección de esta subunidad también es detectada fuera de los cloroplastos durante la senescencia (Chiba et al., 2003). Por otra parte, la incubación de Rubisco con extractos vacuolares también produce su degradación parcial y la acumulación de distintos fragmentos de digestión (Yoshida y Minamikawa, 1996). En cuanto a la variación durante la senescencia de los niveles estables del resto de las proteínas estromáticas, en general parecen acompañar la disminución de Rubisco (Wilson et al., 2002).

\subsection{5- Expresión génica asociada a la senescencia}

Diversos estímulos desencadenan la removilización de nutrientes foliares, que ocurre a expensas del desmantelamiento del cloroplasto y posterior muerte celular. Los cambios ultraestructurales y bioquímicos implicados en estos eventos son comandados a nivel genético y molecular por la maquinaria nuclear. Distintas 
evidencias demuestran que la senescencia requiere de la síntesis de novo de proteínas y de cambios en la expresión génica (v.g., Buchanan-Wollaston, 1997). En conjunto, la síntesis de ARNm y de proteínas disminuye, aunque una proporción de genes aumenta su expresión o se expresa específicamente al comienzo y/o conforme avanza la senescencia (Gan y Amasino, 1997). La mayor parte de los genes involucrados en el síndrome conocidos hasta el presente son aquellos cuyos niveles estables de ARNm aparecen o aumentan durante la senescencia natural o en respuesta a distintos factores, endógenos o ambientales, que aceleran la senescencia (Weaver et al., 1998; Guo et al., 2004; Buchanan-Wollaston et al., 2005). Por su asociación a la senescencia estos genes se denominan SAG ("śenescence-associated genes"), y al menos en Arabidopsis representan alrededor del 10\% del genoma (Gepstein 2004).

Los estudios recientes de expresión génica a gran escala dieron lugar a un panorama global de los cambios moleculares asociados a la ejecución del sindrome. Se han establecido patrones de genes asociados a la senescencia foliar y de otros órganos, los grados de especificidad de la expresión génica frente a distintos factores inductores (i.e., efectos hormonales, oscuridad o déficit de nitrógeno), y las categorías funcionales más representativas (establecidas en el 50-70\% de los genes identificados, He et al., 2001; Guo et al., 2004; Buchanan Wollaston et al., 2005). De acuerdo a la función presunta de sus productos génicos, la mayor parte de los SAGs identificados se relacionan con procesos de degradación de macromoléculas y removilización de nutrientes (i.e., hidrolasas, enzimas involucradas en la removilización de $\mathrm{N}$ ), con mecanismos de defensa y tolerancia al estrés (i.e., respuesta hipersensible y/o protección a daño oxidativo), y con funciones regulatorias y de señalamiento (hormonales y moleculares), mientras que otros SAGs tienen función desconocida (Gepstein 2004, Tabla 1.1). Los principales roles determinados ponen de manifiesto el predominio de reacciones catabólicas y el complejo control molecular del síndrome. La expresión de algunos SAGs es específica de la senescencia, mientras que otros son inducidos en respuesta a distintos factores y también en otros escenarios del desarrollo. Por ejemplo, el factor de transcripción AtWRKY6 se induce durante la senescencia natural y en respuesta a estrés biotico y abiotico (Robatzek y Somssich, 2001). Entre los blancos conocidos de AtWRKY6, SIRK, un receptor con actividad kinasa, es inducido exclusivamente durante la senescencia, mientras que PR1, es activado durante la senescencia y en respuesta al ataque de patógenos (Robatzek y Somssich, 2002). Algunos genes se 
encuentran asociados sólo a determinados tipos de senescencia (v.g., asociada a la ontogenia, o inducida por oscuridad) mientras que otros SAGs son representativos del síndrome cualquiera sea el factor desencadenante (Weaver et al., 1998). Los genes que son particulares de determinados tipos de senescencia podrían relacionarse con el factor inductor y no con la senescencia per sé, y/o pueden ser iniciadores del sindrome, regulando la expresión de otros genes. Los SAGs "corriente abajo" estarían implicados directamente en la ejecución del proceso, es decir, en la degradación y removilización de compuestos. Buchanan-Wollaston et al. (2005) analizan en Arabidopsis los transcriptomas asociados a la senescencia "natural", inducida por oscuridad y por deficiencia de nitrógeno. El solapamiento parcial de los patrones de expresión génica (el 65\% de los SAGs asociados el desarrollo ontogénico se expresan durante la senescencia inducida por oscuridad y en cultivos celulares sometidos a deficiencia de N), y la identidad de los genes comprometidos en todas y cada una de las situaciones reflejan la existencia de distintas vías de regulación, y la convergencia de estas señales en la activación de una maquinaria hidrolítica común (Fig. 1.2). La similitud entre los patrones de expresión génica asociada a la senescencia foliar de Arabidopis y de álamo (Populus tremula), y la identificación de gran cantidad de proteasas ortólogas entre estas especies (Guo et al., 2004) sugieren que el mecanismo molecular del síndrome, y particularmente su ejecución, se encuentra altamente conservado. Entre los genes que codifican proteasas asociadas a la senescencia se encuentra SAG12, cuya expresión es exclusiva de la senescencia foliar asociada a la ontogenia (Lohman et al., 1994). Por su especificidad y marcada inducción, la expresión SAG12 es considerada un diagnóstico molecular del progreso de la senescencia (Pontier et al., 1999).

Los estudios a nivel molecular han permitido esclarecer aspectos clave del síndrome, sin embargo este enfoque presenta importantes limitaciones. En primer lugar, aquellos genes cuya expresión aumenta durante la senescencia pero que están poco representados o ausentes en las bases de datos de ESTS o $c D N A$, en general quedan excluídos en los análisis de expresión génica (Gepstein et al., 2003). Por otra parte, el nivel de tránscrito no siempre es indicativo del nivel estable de la correspondiente proteína. El nivel de ARNm de D1, una proteína integral del PSII, disminuye durante la senescencia, sin embargo, y a pesar de su alta tasa de recambio, los niveles de proteína permanecen constantes (Droillard et al., 1992). Los cambios en los niveles estables de ARNm o de proteína son algunos de los posibles niveles de 
control de la actividad de una proteína (Huber y Hardin, 2004). En el caso proteínas con funciones enzimáticas, la actividad puede estar sujeta a distintos mecanismos de regulación (i.e., maduración de péptidos, fosforilación, condiciones redox, concentración de cofactores, localización subcelular, etc).

Una aproximación alternativa que ha permitido identificar genes con importantes efectos sobre la senescencia es el análisis de colecciones de plantas mutantes, para la detección de genotipos con senescencia alterada y posterior identificación del gen implicado (Woo et al., 2001; Yoshida et al., 2002; Woo et al., 2002).

Tabla 1.1 Principales categorías funcionales de los genes asociados a la senescencia. Modificado de Gepstein et al. (2004) y Buchanan-Wollaston et al. (2005).

\begin{tabular}{|l|c|}
\hline Hidrólisis de macromol éculas & $\begin{array}{c}\text { Proteasas cisteínicas, nucleasas, lipasas, fosfolipasas, } \\
\text { genes de ubiquitinación }\end{array}$ \\
\hline Transporte de nutrientes & $\begin{array}{c}\text { Permeasa, transportadores de amonio, } \\
\text { trasportadores ABC }\end{array}$ \\
\hline Estrés biótico y abi ótico & $\begin{array}{c}\text { Cinamil alcohol deshidrogenease, } \\
\text { proteina tipo patatina }\end{array}$ \\
\hline Daño oxidativo / destoxificaci ón & $\begin{array}{c}\text { Glutation transferasa, dihidroascorbato reductasa, catalasa } \\
\text { Cu/Zn superoxido dismutasa dioxigenasa, glioxilasa }\end{array}$ \\
\hline Factores de transcripción & $\begin{array}{c}\text { Representantes de las familias WRKY; } \\
\text { MYB, GRAS, ribonucleoprote ínas }\end{array}$ \\
\hline Señalamiento & $\begin{array}{r}\text { proteínas de uni ón a Ca+t, receptores con actividad quinasa, } \\
\text { proteínas RAS de uni ón a GTP }\end{array}$ \\
\hline
\end{tabular}


Fig.1.2 Modelo que ilustra las distintas vías inductoras de la senescencia, su superposición, y convergencia. Tomado de Buchanan-Wollaston et al. (2005).

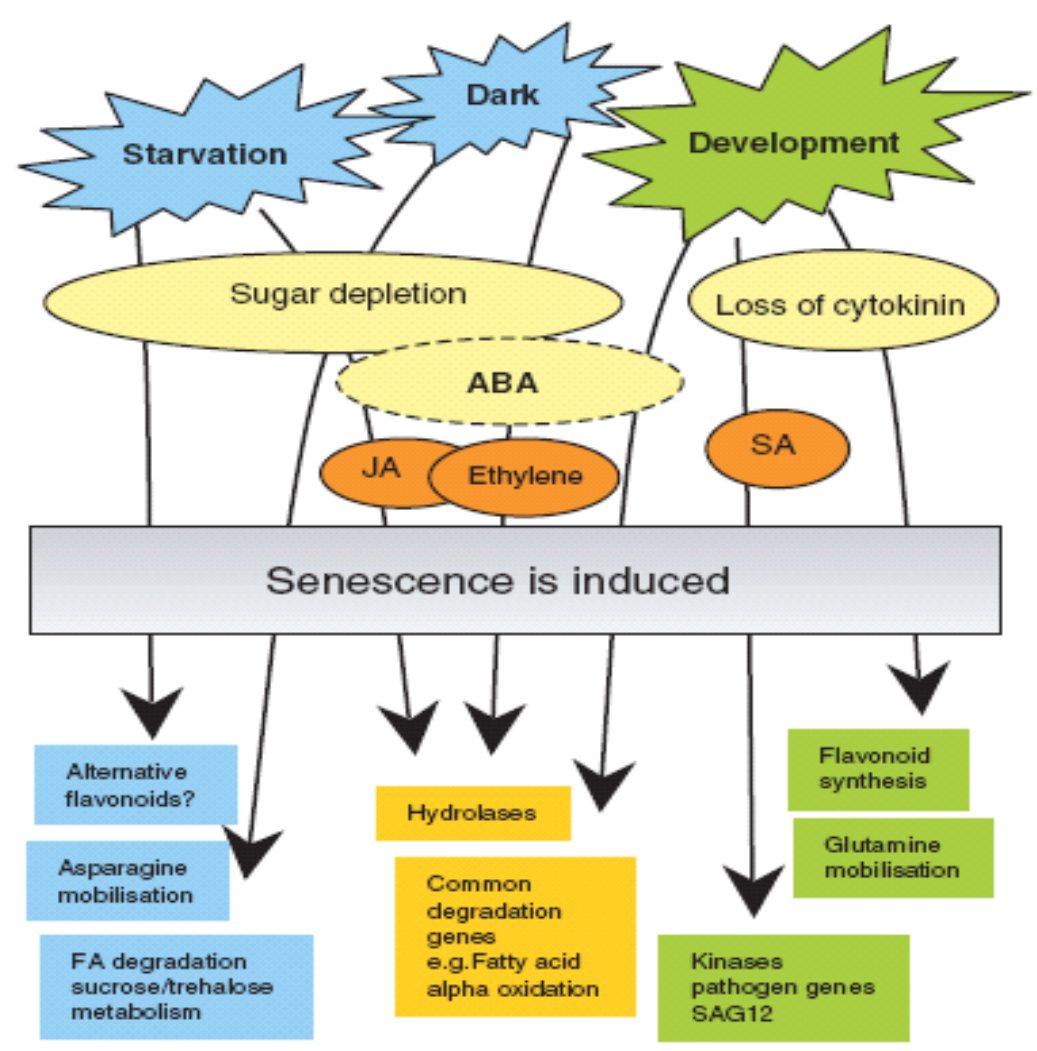

\section{2- La maquinaria proteolítica de la célula vegetal}

Las proteasas cumplen múltiples e imprescindibles funciones líticas $\mathrm{y}$ regulatorias a lo largo de la ontogenia de la planta, v.g., en la embriogénesis, germinación, desarrollo, senescencia y muerte, y en respuesta a enfermedades y otros agentes externos. Involucradas en la modificación, el recambio y degradación de distintas proteínas, las proteasas participan en diversos procesos, desde la eliminación de represores específicos a la removilización de proteínas de reserva durante la germinación, en la maduración de enzimas, el señalamiento hormonal, y en procesos fotomorfogénicos y de PCD (Callis y Vierstra, 2000). Según el 
aminoácido que ocupa el centro catalítico, las proteasas se agrupan en cuatro grupos mecanísticos principales: (cys) cisteínicas, (ser) serínicas, (asp) aspárticas, y metaloproteasas (que requieren un catión, en general $\mathrm{Zn}^{++}$como cofactor). Los distintos tipos mecanísticos reconocen uno o más sitios específicos de corte (v.g., las proteasas serínicas usualmente cortan en la posición carboxilo terminal de los residuos Arg y Lys). La síntesis de novo de proteasa, la maduración controlada de sus precursores inactivos, y la presencia de inhibidores específicos son mecanismos de regulación de la actividad proteolítica, y representan distintas estrategias que permiten llevar a cabo procesos hidrolíticos manteniendo la integridad y homeostasis celular. Por ejemplo, el daño oxidativo desencadena la muerte celular a través de la activación de un grupo de proteasas cisteínicas, que en condiciones normales se encuentran inactivadas por un inhibidor endógeno (Solomon et al., 1999). La compartimentalización no sólo es una barrera física a la degradación de proteínas, sino que puede afectar el grado de actividad proteolítica según el $\mathrm{pH}$ del compartimiento o la presencia de cofactores. La proteólisis puede estar condicionada por factores del sustrato. A través de la ubiquitinización gran cantidad de proteínas son marcadas para su degradación (Moon et al., 2004). El mecanismo de degradación de LHCII en respuesta a la aclimatación lumínica implica su fosforilación y posterior migración lateral en la membrana tilacoidal, quedando expuesta de esta manera a la acción de una proteasa estromática (Yang et al., 1998).

Representantes de las distintas clases mecanísticas de proteasas se encuentran en todos compartimientos celulares, en forma soluble o asociadas a membrana, libres o en complejos proteolíticos, con distintos requerimientos bioquímicos para su actividad, en algunos casos dependiente de ATP o de $\mathrm{Ca}^{++}$. Gran parte de las proteasas poseen señales de direccionamiento a la vía secretoria (Beers et al., 2003), y particularmente muchas proteasas cisteínicas se localizan en la vacuola central, el principal compartimiento lítico de la célula, análogo al lisosoma de la célula animal (De 2000). El sistema de complejos proteolíticos de la célula vegetal comprende a la familia CLP, con representantes homólogos a sistemas proteolíticos procariotas, de localización cloroplástica y mitocondrial, y el Proteasoma, complejo multimérico que participa en la degradación de proteínas nucleares y citosólicas a través de la ruta de ubiquitinación y otras vías. Los procesos autofágicos son parte de la maquinaria de degradación de proteínas, a través de los cuales proteínas y otros componentes del 
citosol son incorporados y degradados por la vacuola central (Thompson y Vierstra 2005).

Las proteasas cisteínicas son el tipo mecanístico más conocido debido a su alta representación en numerosos procesos líticos, como la xilogénesis (Funk et al., 2000), la removilización de proteínas de reserva durante la germinación de semillas (Okamoto y Minamikawa, 1999; Toyooka et al., 2001), la respuesta al déficit hídrico (Khanna -Chopra et al., 1999; Yamada et al., 2000), y distintos tipos de PCD (Hatsugai et al., 2004). La estructura y catálisis de la mayoría de las proteasas de este grupo se corresponde con la proteasa modelo papaína (Beers et al., 2003). Por su expresión y/o actividad, las proteasas cisteínicas cumplen un rol protagónico en la senescencia. Son sintetizadas como zimógenos inactivos, y para su activación es necesaria la remoción del propéptido, que es mediada por otra proteasa o bien ocurre en forma autocatalítica por activación dependiente del pH (Holwerda et al., 1990). En general la actividad hidrolítica requiere un ambiente reductor, y algunas cisteinproteasas también requieren $\mathrm{Ca}^{++}$(Safadi et al., 1997). Los óptimos de actividad establecidos in vitro varían en el rango de $\mathrm{pH}$ de 4-6. De acuerdo a sus secuencias aminoacídicas y a la actividad proteolítica medida en fraccionamientos subcelulares, la mayoría de las proteasas cisteínicas se localizan en vacuolas, aunque hay ejemplos de ubicación en otras organelas (v.g., Distefano et al., 1997). Experimentos con inhibidores específicos de proteasas cisteínicas indican que este tipo de actividad proteolítica también tendría lugar en cloroplastos (Sokolenko et al., 1997; Georgakopoulo et al., 2002).

En general, las proteasas aspárticas se detectan en tejidos específicos como el endosperma y tejido nucelar de semillas, el espacio extracelular de hojas y anteras. A nivel subcelular se localizan particularmente en vacuolas, cuerpos proteícos en semillas y en el apoplasto (Mutlu y Gal, 1999). Una excepción es CND41, de localización cloroplástica (Nakano et al., 1997). Se encuentran como dímeros o monómeros, y en todos los casos estudiados la actividad aspártica requiere $\mathrm{pH}$ ácido, usualmente entre 2 y 5 . Se conoce poco sobre la regulación y función de estas proteasas en plantas. Al igual que las proteasas cisteínicas, la maduración y activación de las proteasas aspárticas implica la remoción del propéptido, aunque se desconoce si ocurre mediante la intervención de otras proteasas o por autocatálisis dependiente del pH (Mutlu y Gal, 1999). Las evidencias indican que proteasas aspárticas participan en la maduración de proteasas vacuolares y en la degradación 
de proteínas de reserva en semillas. Otros miembros de este grupo están implicados en la diferenciación de células del xilema y en la respuesta a patógenos y frente a otras condiciones de estrés (Simões y Faro, 2004). La proteasa CND41 tendría función dual, dado que muestra actividad proteolítica in vitro, y posee dominios de unión a $\mathrm{ADN}$ (Kato et al., 2004).

Las metalo-proteasas usualmente requieren $\mathrm{Zn}^{++}$para su activación, y en algunos casos su funcionamiento es dependiente de ATP. A nivel subcelular se encuentran en el apoplasto, cloroplastos y mitocondrias. Las metalo-proteasas del espacio extracelular se asocian a sistemas de defensa frente a patógenos (Liu et al., 2001), o a procesos vinculados al desarrollo, como la senescencia y PCD de cotiledones (Delorme, 2000). En el interior celular, las metalo-proteasas MPP y SPP participan en el procesamiento de proteínas, removiendo las señales de tránsito mitocondriales y cloroplásticas, respectivamente (Ritcher y Lamppa, 1999; Moberg et al., 2003). Otras metalo-proteasas plastídicas llevan a cabo funciones de degradación y recambio de proteínas. La proteasa del estroma del cloroplasto EP1 es responsable de la degradación parcial de Rubisco en Pisum sativum L. (Bushnell et al., 1993). Las metalo-proteasas de la familia FtsH son probablemente las más estudiadas (Clarke 2005). FtsH1 se ubica en la cara estromática de los tilacoides, y participa en el recambio de la proteína D1 asociado a la fotoinhibición del PSII. FtsH6 estaría involucrada en la degradación de LHCII (Żelisco et al., 2005). Las proteasas FtsH también funcionan como chaperonas (Estelle 2001).

El grupo de proteasas serínicas presenta la mayor diversidad de localizaciones y funciones en la célula vegetal. Las proteasas de este tipo se distribuyen en prácticamente todos los compartimientos celulares: cloroplastos, mitocondrias, vacuola, RE, núcleo y apoplasto, donde se concentra gran parte de las actividades serínicas conocidas. Se han identificado proteasas serínicas con funciones sumamente específicas, en especial las serin-proteasas del tipo subtilisinas. Representantes de esta familia participan en el señalamiento en distintos eventos del desarrollo, i.e., formación de estomas (Berger y Altman, 2000), desarrollo de raíces adventicias (Neuteboom et al., 1999), formación de la cutícula (Tanaka et al., 2001), percepción de brasinosteriodes (Li et al., 2001), etc. Las proteasas Deg son otro grupo de proteasas serínicas, de localización cloroplástica, en la membrana tilacoidal. La función de estas proteasas es desconocida, aunque se cree que podrían participar en la degradación de D1 (Estelle 2001). Al igual que FtsH, las proteasas Deg poseen 
función chaperona, particularmente en situaciones de estrés térmico (Estelle 2001). Entre las proteasas serínicas se encuentran integrantes de la familia Hsp100/CLP.

La mayor parte de las proteasas Clp son diméricas con actividad dependiente de ATP, que funcionan formando complejos tetraméricos, de localización mitocondrial y cloroplástica. Cada dímero se compone de una unidad regulatoria dependiente de ATP, i.e., ClpA, ClpB, ClpX codificadas por el núcleo, y una unidad catalítica, ClpP con actividad serínica, codificada por el genoma plastídico. La función de estas proteasas se desconoce, aunque las evidencias indican su participación en el recambio y en la regulación de la traducción de proteínas cloroplásticas, y en la tolerancia a distintos tipos de estrés, particularmente en la respuesta a altas temperaturas (Sjögren et al., 2004). Su participación en la senescencia es discutida (Weaver et al., 1999; Estelle 2001).

El sistema proteasoma/ ruta de la ubiquitina opera en el citoplasma y en el núcleo celular. El proteasoma es un complejo multimérico y multicatalítico, que en si mismo representa un compartimiento de degradación proteolítica, que incluye actividad de proteasas serínicas, cisteínicas y tipo treonina, específica de este sistema (Baurneisteister et al., 1998). La mayoría de las proteínas degradadas por el proteasoma son previamente ubiquitinadas. Esta ruta incluye la maquinaria de ubiquitinación, conformada por los complejos E1 y E2 de activación y conjugación de ubiquitina/s al sustrato, dependiente de ATP, y distintos complejos E3 de unión al proteasoma. Este sistema de degradación está involucrado en la regulación del señalamiento por distintas hormonas y del fitocromo (Moon et al., 2004). La regulación de la actividad del proteasoma depende en gran medida de la glicosilación y fosforilación de las distintas subunidades (Callis y Vierstra, 2000; Vierstra 2003).

A diferencia del sistema proteasoma, la autofagia implica la degradación no selectiva y masiva de proteínas y otros componentes citoplasmáticos, cuya hidrólisis tiene lugar en la vacuola central. En levaduras, las vías autofágicas incluyen 1-la invaginación del tonoplasto e internalización de componentes citosólicos (“microautofagia"), 2-la formación de vesículas derivadas del sistema de secreción, que bordean y encierran porciones de citoplasma (autofagosomas), que son transportados a la vacuola central donde son degradados ("macroautofagia"), o 3- o la internalización de organelas enteras (v.g., peroxisomas, "pexofagia", Thompson y Vierstra 2005). Este sistema permite el reciclado de proteínas y otros componentes celulares a través de su degradación por proteasas y otras enzimas hidrolíticas 
vacuolares, a la vez que se mantiene la integridad de la vacuola central. Se han identificado componentes de las vías autofágicas en Arabidopsis (v.g., Doelling et al. 2002), posiblemente involucrados en el reciclaje de $\mathrm{N}$ en situaciones de estrés nutricional.

\subsection{Degradación de proteínas durante la senescencia}

Por su ubicación, las proteasas cloroplásticas han sido las principales candidatas a participar en la degradación de las proteínas fotosintéticas (la mayor cantidad de proteínas de la célula), sin embargo no hay evidencias sobre cambios de actividad de proteasas cloroplásticas durante la senescencia (Tabla 1.2). Los análisis de genotipos mutantes knock out para las proteasas cloroplásticas FtsH, CND41, y Clp revelan funciones vitales para el desarrollo y funcionamiento normal del cloroplasto, pero no para la removilización masiva de proteínas durante la senescencia (Kato et al., 2004; Żelisko, A 2005; Clarke et al., 2005). La expresión (ARNm) de la subunidad regulatoria ERD1 de la proteasa CLP aumenta durante la senescencia foliar (Nakabayashi et al., 1999), sin embargo, los niveles de la proteína disminuyen (Weaver et al., 1999). Los aumentos de actividad proteolítica asociados a la senescencia tienen lugar en compartimientos extraplastidiales. En peroxisomas se detectan incrementos de actividad cisteínica y serínica durante la senescencia (Distefano et al., 1997). En el espacio extracelular aumenta la actividad subtilisina y de metalo-proteasas durante la senescencia de trigo y zapallo, respectivamente (Roberts et al., 2003; Delorme et al., 2000). Por su localización, las proteasas apoplásticas no estarían directamente implicadas en la degradación de proteínas cloroplásticas, pero podrían ser parte del proceso. En avena, la toxina fúngica victorin causa la fragmentación de la subunidad grande de Rubisco, por actividad de una proteasa cisteínica (Navarre y Wolpert, 1999). Esta proteasa cisteínica es activada a través de una cascada de señales iniciada por las proteasas serínicas extracelulares SAS1 y SAS2 (Coffeen y Wolpert, 2004).

Los niveles de ARNm de algunos componentes del proteasoma y de la ruta de ubiquitinación se incrementan en hojas senescentes (Buchanan-Wollaston et al., 2005), aunque de acuerdo a su función regulatoria y localización citosólica/ nuclear, la participación de este sistema en la degradación masiva de proteínas fotosintéticas 
es poco probable. Si bien la inactivación de ciertos componentes del proteasoma produce demoras en la senescencia foliar, este hecho estaría relacionado con defectos en la regulación de represores del síndrome (Woo et al., 2001). La autofagia contribuye al reciclado de gran cantidad de proteínas. Sin embargo, la inactivación de componentes esenciales de las vías autofágicas acelera la senescencia foliar (Doelling et al., 2002). Este fenotipo sugiere que el bloqueo de la degradación de proteínas citosólicas induce la degradación de proteínas del cloroplasto, y que la vía autofágica no sería un mecanismo de degradación de proteínas fotosintéticas. Las proteasas más representativas de la senescencia foliar son de localización vacuolar, la mayoría del tipo cisteínicas (Holwerda, et al., 1990; Kinoshita et al., 1999). En la colección de ESTs asociada a la senescencia de Arabidopsis de Guo et al. (2004), 235 ESTs corresponden a proteasas cisteínicas, 5 ESTs a proteasas aspárticas y 3 ESTs a proteasas serínicas. La correlación entre la expresión génica y la actividad proteolítica de estas proteasas ha sido analizada en muy pocos casos. El aumento en los niveles de tránscrito de las proteasas cisteínicas asociadas a la senescencia VPE, SAG2 y SAG12 se correlaciona con aumentos en el nivel de proteína y/o actividad (Kinoshita et al., 1999; Grbic 2003). Por otra parte, la expresión (ARNm) de las proteasas cisteínicas asociadas a la senescencia poscosecha de brócoli se registra en las primeras $24 \mathrm{~h}$ luego de la cosecha, mientras que el pico de la actividad proteolítica ocurre $72 \mathrm{~h}$ después, en simultáneo con la disminución del nivel de proteínas (Coupé et al., 2003). La actividad de la proteasa cisteínica DC-CP1, implicada en la senescencia floral de Dianthus caryophyllus L., es regulada por un inhibidor específico cuya expresión disminuye durante la senescencia (Sugawara et al., 2002). La actividad de proteasas cisteínicas implicadas en la senescencia de nódulos radicales de poroto es dependiente del estado redox celular, y se incrementa conforme disminuye el $\mathrm{pH}$, a medida que cae el contenido de ácido ascórbico y otros antioxidantes (Beyene et al., 2006). Estos ejemplos indican que distintos mecanismos regulan la actividad de las proteasas involucradas en la senescencia, y que la actividad proteolítica no se correlaciona necesariamente con los cambios en los patrones de expresión génica expresados como cambios en los niveles de ARNm. Representantes de todos los tipos de proteasas/ sistemas de proteólisis se relacionan de una u otra manera con la senescencia foliar, aunque se desconoce cual es la relevancia y la función particular de cada uno de ellos. 
Tabla 2.1 Proteasas y/o actividades proteoliticas representativas de la senescencia

\begin{tabular}{|c|c|c|c|c|c|c|}
\hline $\begin{array}{l}\text { Tipo de } \\
\text { Proteasa }\end{array}$ & Denominación & Especie analizada & $\begin{array}{l}\text { Nivel de } \\
\text { análisis }\end{array}$ & $\begin{array}{l}\text { Localización } \\
\text { subcelular }\end{array}$ & Observaciones particulares & Referencias \\
\hline Cisténica & SAG12 & Arabidopsis & $\begin{array}{l}\text { ARNm/ } \\
\text { proténa }\end{array}$ & $?$ & $\begin{array}{l}\text { Expresión específica de } \\
\text { la senescencia }\end{array}$ & Grbic, 2003 \\
\hline Cisténica & SAG2/Aleu & Arabidopsis, tabaco, & $\begin{array}{l}\text { ARNm/ } \\
\text { protéina }\end{array}$ & vacular & & Grbic, 2003 \\
\hline Cisténica & RD21 & Arabidopsis & $\begin{array}{l}\text { ARNm/ } \\
\text { proténa }\end{array}$ & vacuolar & $\begin{array}{l}\text { Maduración dependiente del pH } \\
\text { Expresión asociada al déficit } \\
\text { hídrico }\end{array}$ & Yanada et al., 2000 \\
\hline Cisteínica & VPE & Arabidopsis & $\begin{array}{l}\text { ARNm/ } \\
\text { proteína }\end{array}$ & vacuolar & & Kinoshita et al., 1999 \\
\hline Cisteínicas & $\begin{array}{c}\mathrm{BoCP} 1, \\
\mathrm{BoCP} 2, \\
\mathrm{BoCP} 3, \mathrm{~B} 0 \mathrm{CP} \\
4\end{array}$ & Brassica oleracea & $\begin{array}{l}\text { ARNm/ } \\
\text { actividad }\end{array}$ & $?$ & $\begin{array}{l}\text { BoCP1,24 y BoCP3 son } \\
\text { homólogas a RD21 y RD19 de } \\
\text { Arabidopsis, respectivamente }\end{array}$ & Coupé et al., 2003 \\
\hline Cisténicas & DC-CP & Dianthus caryophyllus & $\begin{array}{l}\text { ARNm/ } \\
\text { actividad }\end{array}$ & $?$ & $\begin{array}{l}\text { Regulación de la actividad } \\
\text { por la presencia de un } \\
\text { inhibidor }\end{array}$ & Sugawara et al., 2002 \\
\hline $\begin{array}{l}\text { Metalo - } \\
\text { proteasa }\end{array}$ & Csl.MMP & Cucumis sativus & & apoplasto & & Yamauchi et al., 2002 \\
\hline Subtilisina & & Trigo & actividad & apoplasto & & Robers et al.,2003 \\
\hline Cisténicas & EP2, EP6 & \multirow{3}{*}{ Poroto } & \multirow{3}{*}{ actividad } & \multirow{3}{*}{ peroxisomas } & \multirow{3}{*}{$\begin{array}{l}\text { Óptimo de actividad } \\
\text { a pH neutro }\end{array}$} & \multirow{3}{*}{ Distefano et al., 1997} \\
\hline Serínicas & $\begin{array}{l}\text { EP1,EP2, } \\
\text { EP4 }\end{array}$ & & & & & \\
\hline $\begin{array}{l}\text { Metalo - } \\
\text { proteasa }\end{array}$ & EP7 & & & & & \\
\hline
\end{tabular}


En síntesis, pese a la relevancia biológica y agronómica de la senescencia foliar, se ignora su mecanismo de ejecución y cuales son las proteasas implicadas en este proceso. El conocimiento actual sobre el tema presenta distintas limitaciones. En primer lugar, a través de estudios moleculares se han identificado gran cantidad de proteasas candidatas a participar en la senescencia, pero existen evidencias sobre distintos tipos de regulación de la actividad proteolítica involucrada en el síndrome, por lo que otras proteasas aún desconocidas podrían participar, incluso ser claves en este proceso. En segundo lugar, la degradación masiva de proteínas cloroplásticas es acompañada por el aumento de expresión y/o actividad de proteasas que se localizan extraplastidialmente. Este hecho representa una paradoja, y su comprensión requiere una mayor investigación, que permita vislumbrar posibles cambios estructurales y/o de compartimentalización subcelular, o bien la ocurrencia de vías de transporte y degradación de proteínas todavía desconocidas. En este sentido, prácticamente se desconocen los sustratos y las funciones específicas de las proteasas que de una $\mathrm{u}$ otra manera (nivel de expresión y/o actividad), se encuentran asociadas a la senescencia.

La hipótesis principal que dio lugar a esta Tesis es que la degradación masiva de proteínas foliares durante la senescencia es llevada a cabo, al menos parcialmente, por proteasas extraplastidiales, y que este proceso involucra otro/s compartimiento/s celular/es además del cloroplasto. Considerando la falta de conocimiento sobre los aspectos bioquímicos y de regulación de la actividad proteolítica responsable del síndrome, este trabajo se basó en el estudio de proteasas cuya actividad se encuentra asociada a la senescencia (es decir, cuya actividad aparece de novo o aumenta durante este sindrome). Para esto se plantearon los siguientes objetivos:

1. Establecer los cambios en los niveles estables de proteasas y correlacionarlos con la actividad proteolítica asociada a la senescencia foliar. Esta aproximación se basó en la marcación química de proteasas y el análisis in vitro de la actividad proteolítica, incluyendo la caracterización de las proteasas y su localización a través de fraccionamientos subcelulares (Capitulo 2). 
2. Determinar in vivo, a través de microscopía laser confocal, la localización subcelular de la actividad proteolítica asociada a la senescencia foliar, y determinar la posible relocalización de proteínas cloroplásticas hacia compartimientos líticos durante la senescencia. Para esto se utilizaron distintos marcadores de compartimientos líticos y sustratos fluorescentes de proteasas. También se examinaron líneas mutantes con expresión de la proteína fluorescente verde (GFP) direccionada a cloroplasto, o con una proteasa específica de la senescencia fusionada a GFP (Capitulo 3).

3. Identificar proteasas cuya actividad se encuentre asociada a la senescencia, y determinar su función en este síndrome. Para este objetivo, el análisis de actividad proteolítica in vitro representó el punto de partida de un estudio de genética reversa utilizando líneas knock out para las actividades proteolíticas asociadas a la senescencia (Capitulo 4). 


\section{CAPITULO 2}

Análisis de la actividad de proteasas asociada a la senescencia foliar de trigo. Tipos mecanísticos y detección subcelular in vitro. 


\section{RESUMEN}

Se realizó un análisis cuali- y cuantitativo de la actividad de proteasas asociada a la senescencia foliar de trigo, y se examinó su localización subcelular. Este trabajo se concentró principalmente en las proteasas del tipo cisteínicas, dada la representatividad de este tipo mecanístico en distintos estudios sobre senescencia foliar en diversas especies. Por medio de marcación química con el inhibidor biotinilado específico de proteasas cisteínicas, DCG-04, se detectó un grupo de al menos cinco proteasas que está presente en hojas no senescentes y cuyo nivel aumenta marcadamente durante la senescencia foliar inducida por oscuridad. En experimentos de actividad in vitro en gel (zimograma), se observó que estas proteasas son activas solo en condiciones restringidas de $\mathrm{pH}$ ácido (menor que 4,5), y únicamente en las muestras correspondientes a hojas senescentes, lo que sugiere un estricto control de la actividad de estas proteasas. De acuerdo al pH óptimo de proteólisis detectado, se exploró la ubicación subcelular de estas enzimas en compartimientos ácidos. La marcación con DCG-04 de fracciones subcelulares enriquecidas en vacuolas de hojas senescentes indica que las proteasas detectadas se localizarían en la vacuola central. En los extractos totales de hojas también se detectó el aumento de actividad asociado a la senescencia de dos proteasas no cisteínicas, con un óptimo de actividad a $\mathrm{pH}$ 5,0, y cuya localización subcelular no fue determinada. Experimentos de actividad proteolítica asociada a la senescencia foliar "natural" y provocada por déficit hídrico demostraron que el patrón de proteasas detectado es característico de la senescencia foliar, en forma independiente del factor desencadenante del proceso. Estas proteasas podrían estar implicadas en un proceso de degradación masiva de proteínas cuya ejecución sería puesta en marcha por los distintos factores que desencadenan o aceleran la senescencia foliar. 


\subsection{INTRODUCIÓN}

El proceso de degradación de proteínas que ocurre durante la senescencia foliar ha sido estudiado a distintos niveles, entre ellos el más explorado quizás sea el nivel de expresión génica. De los 6500 ESTs asociados a la senescencia (alrededor de 2500 genes), el 7\% corresponde a enzimas hidrolíticas, entre ellas proteasas y genes involucrados en la degradación de proteínas vía ubiquitinación (Gepstein, 2004). Se han identificado varios SAGs que codifican proteasas, en su mayoría de tipo cisteínicas (Hensel et al., 1993; Lohman et al., 1994; Buchanan-Wollaston, 1997). Sin embargo, en general se desconoce como es la regulación post transcripcional de estos genes, y en definitiva, la regulación de la actividad de las proteasas codificadas por los SAGs. La senescencia tiene lugar bajo control de la expresión génica, pero su ejecución dependería en gran medida de procesos controlados post transcripcionalmente. La maduración y activación de muchas proteasas, entre ellas la mayoría de las proteasas cisteínicas, ocurre de manera post traduccional, y depende de diversos factores, como el $\mathrm{pH}$ del ambiente subcelular en que se encuentran (Wiederanders et al., 2003). La actividad proteolítica también es regulada por compartimentalización, y por la presencia de inhibidores endógenos. La muerte celular programada promovida por estrés oxidativo en soja es regulada por la actividad de cistatinas, inhibidores endógenos específicos de proteasas cisteínicas (Solomon et al., 1999). La expresión de este tipo de inhibidores disminuye en paralelo con un aumento de la actividad proteolítica durante la germinación de trigo (Kuroda et al., 2001). Pocos trabajos sobre actividad proteolítica asociada a la senescencia presentan datos que abarquen la regulación de proteasas a nivel de tránscrito, proteína, y de actividad. RD21 es una proteasa cisteínica cuya expresión aumenta frente al estrés hídrico (Koizumi et al., 1993) y durante la senescencia (Yamada et al., 2001). Sin embargo, una vez sintetizada, RD21 permanece en forma inactiva en el citosol, y su activación es dependiente del $\mathrm{pH}$ y tiene lugar en la vacuola central (Yamada et al., 2001). La regulación de la actividad de RD21 concuerda con los aumentos de expresión durante la senescencia de proteasas de procesamiento involucradas en la maduración de proteasas vacuolares (Kinoshita et al., 1999), que podrían participar en la activación de RD21 y de proteasas localizadas previamente en 
la vacuola. Se ha detectado actividad proteolítica asociada a la senescencia foliar en la vacuola central (Miller y Huffaker, 1985, Feller y Fisher, 1994) y en otros compartimientos subcelulares, como peroxisomas (Palma et al., 2002), o el apoplasto (Roberts et al., 2003). Llamativamente, son pocos los registros de actividad proteolítica asociada a la senescencia en los cloroplastos, donde reside la mayor parte de las proteínas foliares.

La senescencia puede ser desencadenada por distintos factores ambientales (Park et al., 1998; Benbella et al., 1998; Weaver y Amasino 2001), y los patrones de expresión génica asociados a cada caso se solapan parcialmente (Weaver et al., 1998; Buchanan-Wollaston et al. 2005). Se desconoce en que grado las proteasas involucradas en la ejecución del sindrome son específicas de determinados tipos de senescencia. Algunas proteasas cisteínicas se asocian a la senescencia natural $y$ provocada por sequía (Koizumi, et al., 1993; Yamada et al., 2001), mientras que otras sólo son detectadas durante la senescencia cuando esta es desencadenada por deficit hídrico (Khanna-Chopra et al., 1999). Deficiencias en la disponibilidad de $\mathrm{N}$ promueven la senescencia foliar de trébol, que se caracteriza por la inducción de proteasas cisteínicas cuya actividad no es detectada durante su senescencia "natural", u ontogénica (Smith et al., 2005).

El panorama descrito pretende reflejar la complejidad de la regulación de la actividad proteolítica y la brecha en el conocimiento actual sobre la expresión génica y la forma en que tiene lugar la degradación de proteínas durante la senescencia foliar. El trabajo realizado en este capítulo fue orientado a detectar y caracterizar in vitro el tipo de proteasas y actividad proteolítica asociadas a la senescencia foliar en trigo, como etapa natural del desarrollo, o desencadenada por distintos factores (v.g., oscuridad y deficiencias hídricas), incluyendo en este análisis la determinación de grupos mecanísticos y la localización subcelular de las proteasas y sus $\mathrm{pH}$ óptimos de actividad. De acuerdo a la información existente sobre la participación de las proteasas cisteínicas en el proceso de senescencia (Gepstein el al., 2003; Guo et al., 2004) este trabajo está enfocado especialmente al análisis de este grupo de proteasas. 


\section{2 - MATERIALES Y MÉTODOS}

\subsubsection{Condiciones de cultivo y de inducción de la senescencia.}

La mayor parte de los experimentos correspondientes a este capítulo se realizaron con plantas de trigo (cv Buck Poncho) cultivadas en maceta, en cámara de crecimiento a una PPFD de $500 \mu$ moles de fotones $\mathrm{m}^{-2} \mathrm{~s}^{-1}$ y un fotoperíodo de $12 \mathrm{~h}$., a $24^{\circ} \mathrm{C}$. Las plantas se mantuvieron en perlita y se regaron periódicamente con solución nutritiva Hoagland (Hoagland y Arnon, 1950). La senescencia se indujo en plantas de tres semanas colocando las macetas en oscuridad continua. Se consideró a la pérdida de clorofila foliar como parámetro de senescencia. A partir del primer día de oscuridad se efectuaron mediciones diarias de clorofila foliar en la segunda y tercer hoja basal, ambas completamente expandidas, en muestras conformadas por cinco plantas.

\subsubsection{Medición de clorofila foliar y toma de muestras}

Las mediciones de clorofila foliar se efectuaron con el medidor no destructivo SPAD 502 (Minolta Co., Ltd), o por espectrofotometría (Inskeep y Bloom, 1985). Las mediciones se realizaron en la zona central de la lámina foliar. En las mediciones efectuadas con el SPAD se tomó el promedio de tres valores por hoja.

En las muestras seleccionadas para cada experimento, además del valor de clorofila se registró el peso fresco y se determinó el área foliar con un integrador LICOR 3000, USA. Las muestras fueron utilizadas en el momento, o congeladas en nitrógeno líquido y guardadas $\mathrm{a}-80^{\circ} \mathrm{C}$, según el experimento realizado.

\subsubsection{Detección de proteasas de tipo cisteínicas asociadas a la senescencia foliar.}

La detección de proteasas cisteínicas se realizó por marcado con DCG-04, un derivado biotinilado del inhibidor específico de proteasas cisteínicas E64 (trans-epoxi succinilamido (4-guanidino) butano), que se une de forma covalente al sitio activo de 
este tipo de proteasas (Greenbaum et al., 2000, Fig 2.1). Las proteasas biotiniladas fueron detectadas por western blot utilizando el conjugado estreptavidina- peroxidasa. En la Fig. 2.2 se muestra un esquema de este procedimiento que se sintetiza en los siguientes pasos:

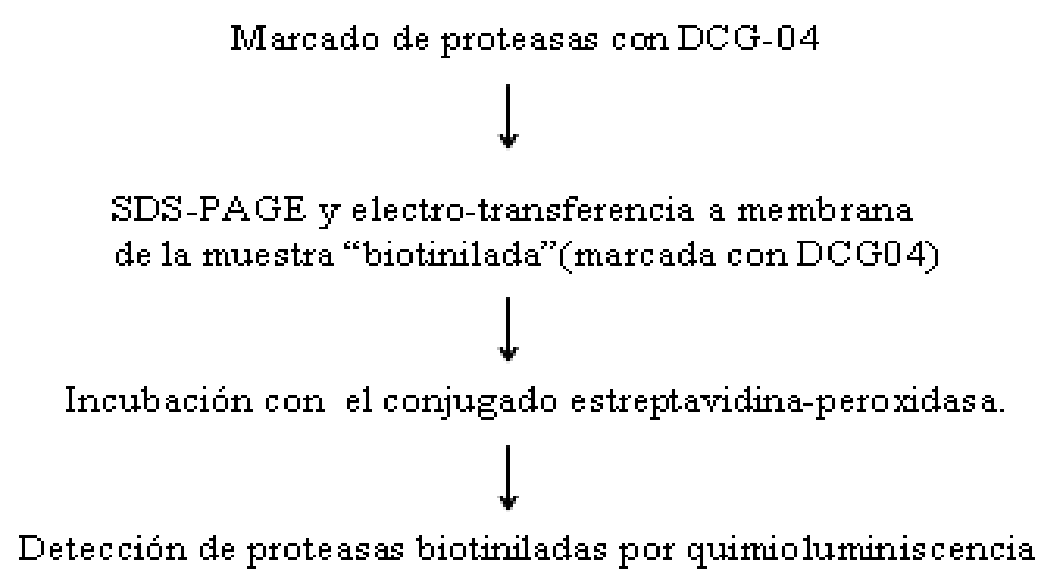

Muestras analizadas

En este experimento se utilizaron hojas senescentes y no senescentes de las plantas descriptas en el punto 2.2.1 Las proteínas foliares solubles se extrajeron con mortero y pilón, en agua destilada fría, macerando $300 \mathrm{mg}$ de tejido con $1 \mathrm{ml}$ de agua. El extracto se centrifugó a 12000 g durante 15 minutos a $4^{\circ} \mathrm{C}$, y la fracción soluble se utilizó para la marcación. Para el análisis de proteínas vacuolares, las fracciones enriquecidas en vacuolas (cuya preparación describo en el punto 2.2.5) se concentraron cinco veces utilizando tubos concentradores Nanosep (Pall Corporation. USA) de $0,5 \mathrm{ml}$ y $10 \mathrm{kDa}$ de corte. 
Figura 2.1. Estructura molecular del inhibidor de proteasas cisteínicas E64 y su derivado biotililado, DCG-04 (tomado de Greenbaum et. al., 2000).

E64

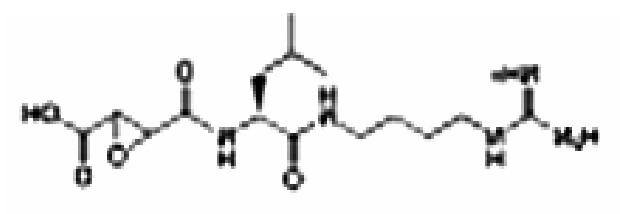

\section{DCG-04}

biotina

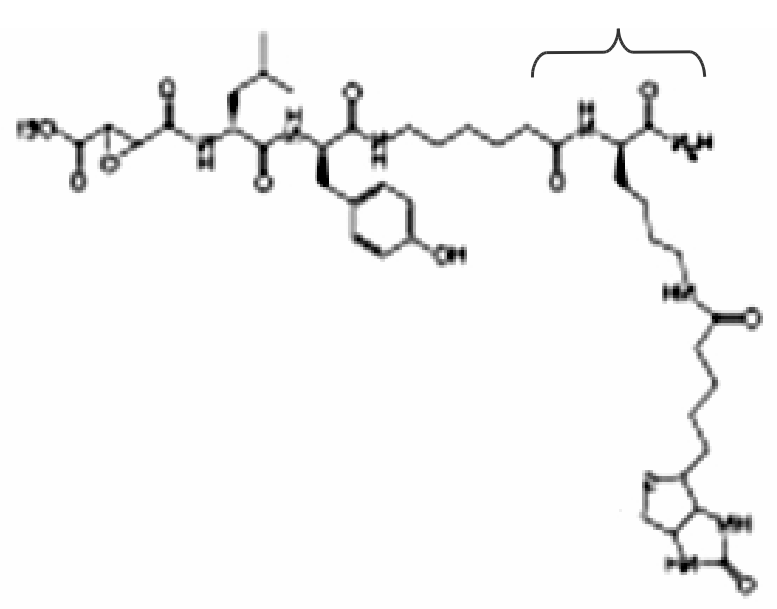

Fig. 2.2 Diagrama esquemático de la marcación de proteasas cisteínicas con DCG-04 (modificado de van der Hoon et al., 2004.)

A)

proteasa

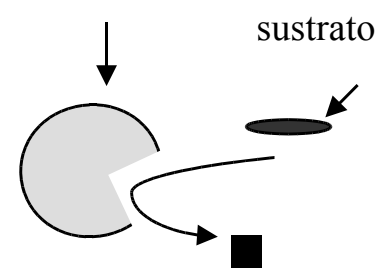

Esquema de

la proteasa

y su sitio activo
B)

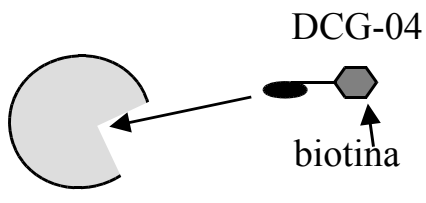

El DCG-04 se une en forma covalente al sitio activo de la proteasa.
C)

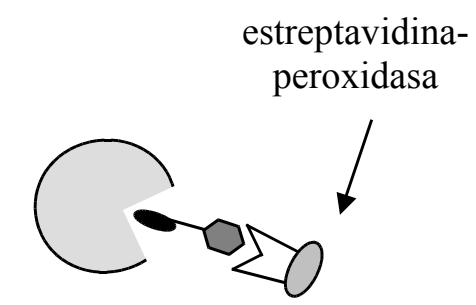

La biotina se detecta con estreptavidina-peroxidasa. 
A- Marcación con DCG-04.

Los extractos de proteínas solubles de hojas o de vacuolas se incubaron con $5 \mu$ molar de DCG-04 (cedido por el Dr. M. Bogyo, Universidad de Standford, USA) en buffer de incubación (acetato de sodio $25 \mathrm{mM}$, cisteína $10 \mathrm{mM}, \mathrm{pH}$ 5), con agitación constante durante cinco horas a temperatura ambiente. El pH de incubación es el óptimo para la actividad proteolítica en hojas de trigo (Zagdanska y Wisnieeski, 1996; Zhang et al., 2005), y para la marcación con DCG-04 (Greenbaum et al., 2000; van der Hoon et al., 2004). Se diluyó un volumen de muestra en tres volúmenes de buffer de incubación. Los volúmenes de trabajo fueron de alrededor de 0,5 ml. Para confirmar la especificidad de la marcación con DCG-04, una fracción de cada muestra se destinó a un experimento de competencia con el inhibidor E64*. En este experimento la muestra control se incubó con $100 \mu$ molar del inhibidor E64 en buffer de incubación con agitación durante una hora. Luego de la preincubación con E64 se incorporó DCG04 a una concentración final $5 \mu$ molar. Las muestras marcadas se precipitaron en acetona enfriada a $-20^{\circ} \mathrm{C}$ y se resuspendieron en buffer de siembra (Tris $25 \mathrm{mM} \mathrm{pH} \mathrm{6,8} \mathrm{SDS} \mathrm{2 \% ,} \mathrm{glicerina} \mathrm{5 \% ),} \mathrm{e} \mathrm{hirvieron} \mathrm{durante} \mathrm{un} \mathrm{minuto.}$

\section{B- Western blot}

Las muestras se separaron en geles SDS PAGE (Laemmli, 1970) de 12\% de acrilamida, a $13 \mathrm{~mA}, 2,30 \mathrm{~h}$ y se electrotransfirieron a membranas de nitrocelulosa (Protran ${ }^{\circledR}$ Scheleicher \& Scheuell), a $100 \mathrm{~mA}$ durante $2 \mathrm{~h}$. Las membranas se bloquearon toda una noche en buffer fosfato salino (PBS T, fosfato de sodio $100 \mathrm{mM}$ pH 7,4, $\mathrm{NaCl} 150 \mathrm{mM}$, Tween 20 0,05\%) con 10\% de leche descremada marca SER.

C- Incubación con estreptavidina-peroxidasa y detección de las proteínas marcadas.

Las membranas se lavaron 5 veces, 5 minutos cada vez, en buffer PBS T, y se incubaron con estreptavidina-peroxidasa (1: 2000, SIGMA Ultrasensitive) durante 3 h. Luego de varios lavados con buffer PBS T, las membranas se revelaron por quimioluminiscencia con un kit comercial (Pelkin Elmer)y películas Kodak (Kodak Scientific Imaging Film)

*excepto donde se especifique lo contrario, todos los reactivos utilizados en esta tesis fueron provistos por Sigma-Aldrich S.A. 


\subsubsection{Análisis de actividad proteolítica in vitro, en geles SDS-PAGE de actividad (zimograma)}

Los zimogramas o geles de actividad son geles SDS-PAGE que contienen gelatina co-polimerizada con la matriz de poliacrilamida. La gelatina es un sustrato general para proteasas de distintos tipos mecanísticos (Bethke et al., 1996). Luego de la electroforesis y de un período de incubación en las condiciones óptimas de $\mathrm{pH}$ y temperatura (determinado de forma empírica) para la actividad de las proteasas, el zimograma es teñido con Coomassie Blue, y las proteasas que han degradado la gelatina se evidencian como bandas claras en el fondo azul de Coomassie. Este sistema permite detectar la actividad in vitro de proteasas y caracterizar la actividad (tipo de proteasa, pH óptimos de actividad, necesidad de cofactores, etc.).

Extracción de proteínas

Las proteínas solubles de extractos totales de hojas se extrajeron con mortero y pilón en buffer Tris $25 \mathrm{mM}$ pH 7,5 cisteína $2 \mathrm{mM}$, PVPP 10\%. Los extractos se centrifugaron a $10000 \mathrm{~g}$, durante $15 \mathrm{~min}$. y la fracción soluble se analizó o guardó a 80 C hasta su análisis.

Desarrollo del zimograma

Los zimogramas se realizaron esencialmente como en Wagstaff et al. (2002). Extractos correspondientes a una misma superficie foliar se diluyeron 1:2 v/v en buffer de actividad (Tris $25 \mathrm{mM}$ pH 6,8, SDS 2\%, glicerina 5\%) y se corrieron en geles de $12 \%$ de acrilamida y $0,04 \%$ de gelatina a $4{ }^{\circ} \mathrm{C}, 13 \mathrm{~mA}$ durante $2,5 \mathrm{~h}$. Luego de la electroforesis para remover el SDS los geles se lavaron en buffer de lavado (acetato de sodio $75 \mathrm{mM}, 2 \%$ de Tritón X-100, DTT $8 \mathrm{mM}, \mathrm{pH} 4,5$ ) durante 1 hora con agitación. El buffer de lavado se reemplazó por un buffer de igual composición pero sin Tritón, y el zimograma se incubó a $37 \mathrm{C}$ durante 16 h., y se reveló con 0,3\% Coomasie Blue (Coomasie Blue 0,3\%, metanol 30\%, ácido acético 10\%).

2.2.4.1. Efecto del pH sobre la actividad proteolítica in vitro. 
Para analizar el efecto del $\mathrm{pH}$ sobre la actividad de las proteasas se revelaron zimogramas corridos como en 2.2.4, lavados e incubados en los siguientes buffers (Tabla 2.1):

Tabla 2.1. Composición de buffers para analizar el efecto del $\mathrm{pH}$ sobre la actividad proteolítica. Para el lavado se

\begin{tabular}{ll}
\hline Buffer & $\mathrm{pH}$ \\
\hline Ac Na 75 mM, DTT 8 mM & $4,5-5,0-5,5$ \\
Tris50 mM, DTT 8 mM & 7,5 \\
\hline
\end{tabular}
incorporó Tritón $(2 \% \mathrm{v} / \mathrm{v})$ en cada de proteasas activas.

buffer.

El tipo mecanístico de las proteasas detectadas se determinó a través del uso de inhibidores específicos (Tabla 2.2). Alícuotas de cada muestra se incubaron con cada uno de los inhibidores a $4{ }^{\circ} \mathrm{C}$ durante los $30 \mathrm{~min}$. previos a la electroforesis. Se incluyeron muestras controles incubadas con los solventes correspondientes. Se realizó un zimograma para cada inhibidor, y en cada caso los inhibidores también se incorporaron a los buffers de lavado e incubación en las concentraciones descriptas.

Tabla 2.2 Características y concentraciones de los inhibidores de proteasas utilizados

\begin{tabular}{|l|l|l|l|}
\hline Inhibidor & Proteasas sensibles & $\begin{array}{l}\text { Concentración } \\
\text { final }\end{array}$ & Solvente \\
\hline E64 & Cisteínicas & $20 \mu \mathrm{M}$ & $\begin{array}{l}\text { agua } \\
\text { destilada }\end{array}$ \\
\hline $\begin{array}{l}\text { PMSF } \\
\text { (Fenil metil- } \\
\text { sulfonil fluoruro })\end{array}$ & Serínicas & $1 \mathrm{mM}$ & metanol \\
\hline Pepstatina & Aspárticas & $40 \mu \mathrm{M}$ & $\begin{array}{l}\text { DMSO } \\
\text { dimetilsulfó } \\
\text { xido) }\end{array}$ \\
\hline Leupeptina & Cisteínicas y Serínicas & $40 \mu \mathrm{M}$ & $\begin{array}{l}\text { agua } \\
\text { destilada }\end{array}$ \\
\hline
\end{tabular}

\subsubsection{Aislamiento de vacuolas de hojas senescentes}


Se prepararon vacuolas a partir de protoplastos de hojas de trigo senescentes (punto 2.2.1), utilizando el método descripto en Bednarek y Raikhel (1991), con modificaciones.

Obtención de protoplastos

Las hojas se cortaron en trozos de $1 \mathrm{~mm}^{2}$ aproximadamente, y se infiltraron con buffer de suspensión (MES $25 \mathrm{mM}$, betaína 0,5 M pH 5,5) en vacío durante 3 min. Una vez infiltrados, los trozos de tejido se sometieron a digestión en buffer de lisis (MES $25 \mathrm{mM}$, betaína $0,5 \mathrm{M}$, celulasa $1 \%$, pectoliasa $0,3 \%$, pH 5,5) en oscuridad durante $2 \mathrm{~h}$. El tratamiento de lisis se interrumpió reemplazando el buffer de lisis por buffer de suspensión con $0,01 \%$ de Rojo Neutro (un compuesto vital, marcador de compartimientos ácidos) y los protoplastos se liberaron por agitación a $75 \mathrm{rpm}$ durante 30 min., y luego se sedimentaron a $50 \mathrm{~g}$ utilizando una centrífuga de mano.

Purificación de vacuolas

Las vacuolas se purificaron por flotación en un gradiente discontinuo de Ficoll. Para esto, los protoplastos se resuspendieron en $2 \mathrm{ml}$ de buffer (Hepes $25 \mathrm{mM}$ pH 7, betaína $0,5 \mathrm{M}, 10 \%$ de Ficoll) pipeteando suavemente para promover la evacuolación de los protoplastos (rotura de los protoplastos y liberación de vacuolas), y se transfirieron a un tubo de centrífuga. El gradiente se generó sobre la fracción de $10 \%$ de Ficoll, agregando cuatro fracciones, de $0,7 \mathrm{ml}$ cada una, de $8,6,2$, y $0 \%$ de Ficoll. El gradiente se centrifugó a $10000 \mathrm{~g}$ durante $20 \mathrm{~min}$ a $4{ }^{\circ} \mathrm{C}$, en un rotor basculante (Ultracentrífuga Beckman Coulter, Optima Max, Rotor Swinging bucket, MLS 50). La fracción con vacuolas se detectó visualmente por la ubicación del Rojo Neutro, en dos bandas definidas, entre 6 y 8 \% de Ficoll. La presencia de vacuolas se constató por observación al microscopio óptico (Lancet Instruments, Modelo L2001A-B). 
Se utilizaron dos anticuerpos contra proteínas vacuolares, una ATPasa vacuolar marcadora de tonoplasto (V ATPasa) cedida por el Dr. M. Maeshima (Univ. de Nagoya, Japón), en una dilución 1:1000, y la proteasa del lumen vacuolar SAG 2, (Grbic, 2003), en una dilución 1:500.

\subsubsection{Cuantificación y cálculo del tamaño molecular de proteínas.}

La concentración de proteínas en solución se midió por el método de Bradford (Bradford, 1976). En el caso de muestras preparadas con SDS, o con gran cantidad de Rojo Neutro, y debido a las interferencias de estas sustancias con la determinación por el método de Bradford, la cantidad de proteína se cuantificó por densitometría de la señal de Coomassie en geles SDS-PAGE con el programa Sigma Gel (v 10 Jandel Scientific). Este programa también se utilizó para calcular el tamaño molecular de las proteínas separadas en geles SDS-PAGE o de la señal en ensayos de inmunodetección. En geles y zimogramas SDS-PAGE se utilizaron marcadores de peso molecular SDS 7 (conjunto de marcadores de 66, 45, 36,29, 24, 20 y $14 \mathrm{kDa}$ ), y Fosforilasa B como marcador de $94 \mathrm{kDa}$.

\subsubsection{Inducción de la senescencia foliar mediada por distintos factores.}

A continuación describo brevemente los tratamientos empleados para analizar la actividad de proteasas asociada a la senescencia foliar desencadenada o acelerada por distintos factores.

\subsubsection{Inducción de la senescencia por déficit hídrico}

Se sometió a déficit hídrico a plantas de trigo (cv Granero INTA) creciendo en macetas de 1 litro rellenas con tierra, en cámara de crecimiento bajo las mismas condiciones que en el punto 2.2.1. Las plantas, dos por maceta, fueron mantenidas a capacidad de campo por dos semanas. El tratamiento de estrés hídrico se impuso por suspensión del riego hasta que el potencial agua del suelo llegó a -0.6 MPa. (los valores de potencial agua fueron calculados a partir de una curva de potencial agua del suelo a distintos porcentajes de humedad edáfica, datos no mostrados). El valor de 
potencial agua se mantuvo por riego controlado y pesada de las macetas en forma periódica. La intensidad del estrés hídrico se estimó a partir del contenido relativo de agua (CRA) de la primera hoja basal de plantas controles y estresadas, que se registró cada tres días desde el inicio hasta el final del experimento. El contenido relativo de agua (CRA) se calculó como en Tambussi et al. (2000):

\section{Contenido relativo de agua $(\mathrm{CRA}) \%=(\mathrm{pf}-\mathrm{ps}) /(\mathrm{ph}-\mathrm{ps}) 100$}

$\mathrm{pf}=$ peso fresco de la hoja

ps $=$ peso seco de la hoja

$\mathrm{ph}=$ peso de la hoja a hidratación máxima.

\subsubsection{Inducción de la senescencia en hojas cortadas y colocadas en oscuridad}

Se indujo la senescencia por incubación en oscuridad de hojas cortadas de la planta después de haber alcanzado su máxima expansión. En este tratamiento se utilizaron plantas de trigo (cv Buck Poncho) provenientes de un cultivo sembrado en el campo, en la Estación Experimental de la Facultad de Ciencias Agrarias y Forestales (UNLP) (34 54' S). Las hojas se cortaron y se colocaron en oscuridad, en bolsas plásticas con papel de filtro humedecido. Una parte del material se destinó para el registro diario de los valores de clorofila.

\subsubsection{Senescencia monocárpica}

El análisis de proteasas asociadas a la senescencia monocárpica se realizó sobre la hoja bandera de plantas de trigo creciendo en el campo, como en 2.2.8.2. Se realizaron muestreos registrando el contenido de clorofila de la hoja bandera, desde la fecha de antesis y a lo largo del tiempo hasta el momento de "amarillamiento" total de las hojas bandera de la mayor parte del cultivo.

\subsection{RESULTADOS}




\subsubsection{Detección de proteasas cisteínicas asociadas a la senescencia foliar de trigo.}

Aunque en hojas senescentes hay ejemplos de aumentos en la expresión y/o actividad de proteasas representativas de todos los distintos grupos mecanísticos (Roberts et al., 2003; Yamauchi, et al., 2002), las proteasas cisteínicas representan el grupo más frecuentemente asociado a la senescencia en la mayoría de las especies estudiadas (Morris et al., 1996; van de Hoorn, 2004). Por lo tanto, y utilizando el marcador específico de proteasas cisteínicas DCG-04, se exploró la presencia de proteasas de este grupo mecanístico en hojas de trigo en distintos estadios de senescencia.

Se analizaron hojas (la segunda y tercera hoja basal) antes y después de inducir la senescencia foliar, colocando la planta en oscuridad. Como hojas senescentes se seleccionaron aquéllas con un contenido de clorofila $40 \%$ menor respecto del valor inicial (medido antes de colocar las plantas en oscuridad). Esta caída se registró en plantas después de cuatro días de tratamiento en oscuridad. Como controles no senescentes se utilizaron la segunda o tercera hoja basal de plantas mantenidas en el fotoperíodo normal de $12 \mathrm{~h}$.

La marcación de extractos totales de hojas senescentes y no senescentes con DCG-04 se muestra en la Fig. 2.3. En hojas no senescentes (NS) se observa un perfil de proteasas cisteínicas conformado por dos bandas, de 36 y $39 \mathrm{kDa}$, y una señal de alrededor de 42-44 kDa, que corresponde a dos proteínas de tamaño similar, no resueltas claramente en esta figura. El mismo perfil se observa en hoias senescentes (S), aunque con una señal significativamente ma detectan una proteasa de $46 \mathrm{kDa}$, y otra de meno La especificidad de la marcación se corroboró c el inhibidor de proteasas cisteínicas E64. Este biLas flechas indican las señales $d_{\mathfrak{l}}$ irrevers ciproteasas cisteínicas, de 46, 42, 39,;teínicas 1 m36 y $27 \mathrm{kDa}$. Las cabezas de flecha:as incub; mindican señal no específica, que ${ }_{J a}$ señal $\mathrm{i}$ Dcorresponde a proteínas marcadastas proteí Fjinespecíficamente, luego de laínicas aumenta durante la senescencia de trigo Sincubación de la muestra con E64.ínicas extraídas de una misma superficie foliar (1Todos los experimentos de marcadoy senescentes (S).

se realizaron a $\mathrm{pH} 5,0$. 


\subsubsection{Las proteasas cisteínicas asociadas a la senescencia foliar son activas en un}

rango restringido de $\mathrm{pH}$ ácido.

Para determinar el efecto del $\mathrm{pH}$ sobre la actividad de las proteasas tipo cisteínicas asociadas a la senescencia de trigo, se analizó la actividad proteolítica in vitro en geles de actividad (zimogramas) incubados a distintos valores de $\mathrm{pH}$

Se realizaron zimogramas para un rango de $\mathrm{pH} 4,0$ a 7,0. En zimogramas a $\mathrm{pH}$ ácido se detectó un grupo de proteasas activas sólo en hojas senescentes (Fig. 2.4.) El patrón de actividad, de al menos cinco bandas de tamaños moleculares similares se asemeja al detectado con el marcador DCG-04 (Fig. 2.3). En este punto debe considerarse que debido a las condiciones "semi-nativas" en que se realizan los zimogramas (la muestra no es desnaturalizada por el agregado de agentes reductores o 
altas temperaturas), los pesos moleculares de las proteasas activas in vitro no pueden ser comparables en forma exacta con los pesos moleculares de las proteasas detectadas con DCG-04, que son desnaturalizadas de forma irreversible luego de la marcación (Materiales y Métodos, punto 2.2.3). Respecto al análisis de actividad en gel, también debe tenerse en cuenta que variaciones en el tiempo y pH de incubación de un zimograma suelen traducirse en ligeras diferencias en el perfil de actividad de una misma muestra (este efecto se observa más adelante, si se compara el perfil de actividad de distintos zimogramas realizados con la misma muestra, en la Figs. 2.4 y 2.5). El conjunto de protesas activas asociado a la senescencia tiene un óptimo de actividad a $\mathrm{pH} 4,0$, y la actividad decrece rápidamente con el aumento de $\mathrm{pH}$ hasta resultar imperceptible a pH 5,0 (Fig.2.5). En la Fig. 2.4 también se detectan dos bandas de actividad, de mayor tamaño molecular. La actividad de estas bandas es visible en hojas no senescentes y se incrementa durante la senescencia. Estas proteasas son activas en un rango más amplio de $\mathrm{pH}$, con un óptimo de actividad a $\mathrm{pH}$ 5,0 (Fig. 2.5). Más allá de los distintos efectos del $\mathrm{pH}$ sobre las actividades proteolíticas detectadas in vitro las proteasas asociadas a la senescencia son activas a pH ácido, similar al del lumen vacuolar y el expacio extracelular.

Fig 2.4. Actividad en gel (zimograma) de proteasas asociadas a la senescencia foliar.

En este zimograma incubado a $\mathrm{pH} 4,0$ se observa, marcada con flechas, la actividad de proteasas cuyos pesos moleculares son 49, 46, 42, 39 y 36 $\mathrm{kDa}$. Este grupo de bandas es activo solo en hojas senescentes (S). Con cabezas de flecha se indican dos actividades, de 61 y 65 kDa., que aparecen en hojas no senescentes (NS) y aumentan durante la senescencia foliar.

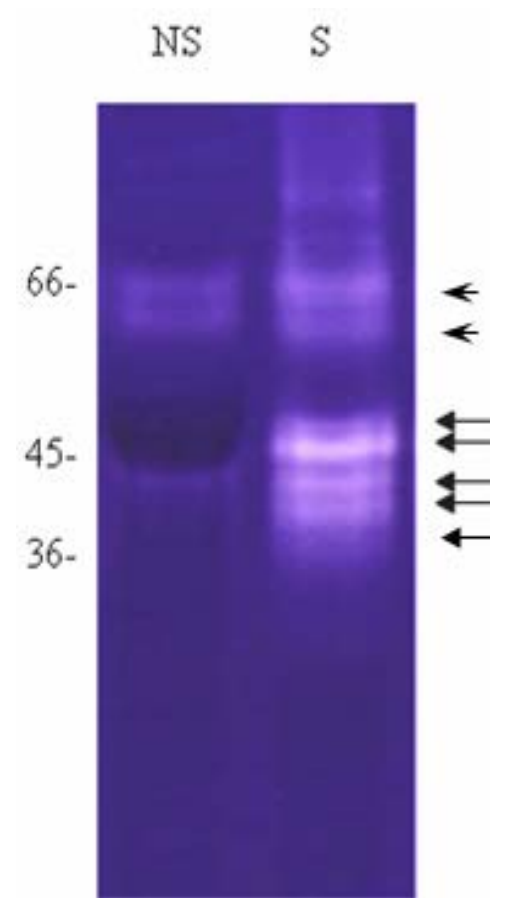


Fig. 2.5 Efecto del $\mathrm{pH}$ sobre la actividad in vitro de proteasas asociadas a la senescencia foliar

La actividad de las proteasas exclusivas de hojas senescentes puede detectarse solo a $\mathrm{pH}$ ácido menor de $\mathrm{pH}$ 5,0 (indicadas con una llave). Los pesos moleculares calculados en este gel son 49 46423936 y $30 \mathrm{kDa}$.

Las dos proteasas cuya actividad aumenta durante la senescencia (señaladas con un paréntesis en esta figura, y cabezas de flechas en la Fig.2.4) son activas en un amplio rango de $\mathrm{pH}$, con un óptimo de

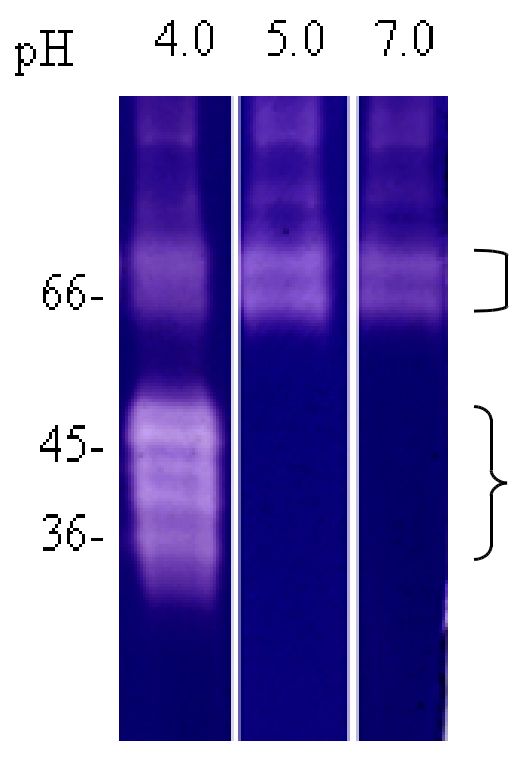
actividad a $\mathrm{pH} 5,0$.

\subsubsection{Determinación del tipo mecanístico de las proteasas asociadas a la senescencia} detectadas en zimogramas.

Se estableció el tipo mecanístico de las proteasas detectadas en zimogramas a través del efecto de inhibidores específicos sobre la actividad a los pH óptimos determinados previamente. El conjunto de proteasas activo a $\mathrm{pH} 4$ en hojas senescentes es inhibido completamente con E64 indicando que estas proteasas son cisteínicas (Fig. 2.6a). Este resultado sugiere fuertemente que el perfil de proteasas cisteínicas detectado con DCG-04 y en zimogramas a pH 4 correspondería a las mismas proteasas.

Las proteasas de 61 y $65 \mathrm{kDa}$. resultan inhibidas con el inhibidor de proteasas aspárticas, pepstatina, y también son parcialmente inhibidas con PMSF, inhibidor de proteasas serínicas (Fig. 2.6b). Los controles correspondientes (Tabla 2.2, Fig. 2.6 b) 
muestran que la inhibición de la actividad proteolítica se debe al efecto específico de los inhibidores, y no al efecto de los solventes (DMSO y metanol). La actividad de estas proteasas tampoco es inhibida por leupeptina, un inhibidor de algunas proteasas serínicas (resultado no mostrado). Esto sugiere que correponderían al grupo de las proteasas aspárticas, aunque cabe la posibilidad de que fueran proteasas serínicas insensibles a los inhibidores convencionales, como es el caso de las proteasas serínicas con actividad de caspasas (Coffen y Wolpert, 2004).

Fig. 2.6. Efecto de inhibidores específicos de proteasas sobre la actividad proteolítica en zimogramas a $\mathrm{pH} 4$ (A) y $\mathrm{pH} 5$ (B)

A) La inhibición total de actividad a $\mathrm{pH} 4$ por E64 indica que las proteasas cuya actividad aparece específicamente en hojas senescentes son de tipo cisteínicas.

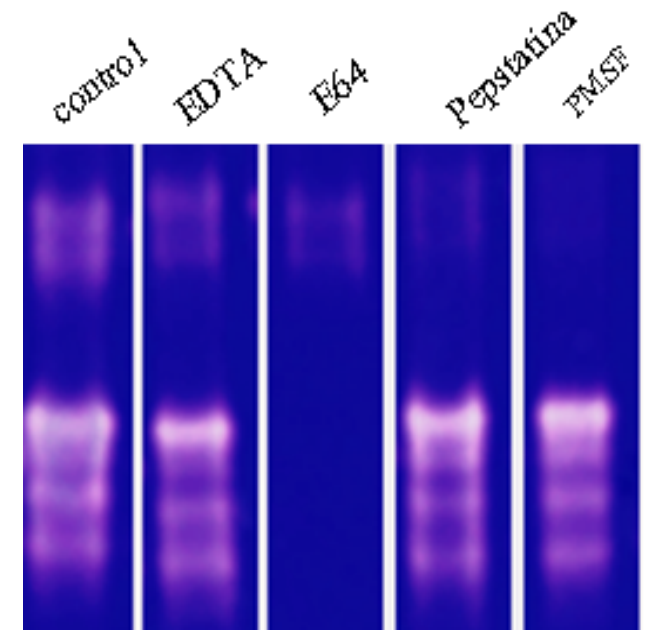

B) Tanto el inhibidor específico de proteasas serínicas (PMSF) como el inhibidor de aspárticas (pepstatina) afectan la actividad de las proteasas activas a pH 5.

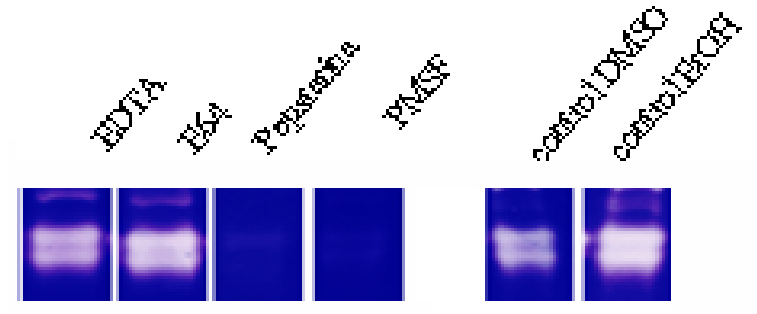




\subsubsection{Las proteasas cisteínicas se localizan en la vacuola.}

2.3.4.1 Preparación de fracciones subcelulares enriquecidas en vacuolas de hojas senescentes

Dado que la actividad de las proteasas cisteínicas asociadas a la senescencia tiene un óptimo in vitro a $\mathrm{pH}$ ácido, el estudio de localización subcelular de estas proteínas comenzó examinando la vacuola central, el mayor compartimiento ácido de la célula. La purificación de vacuolas a partir de protoplastos de hojas senescentes se realizó en cuatro preparaciones independientes, con bajo rendimiento en todos los casos (Fig. 2.7).

Las fracciones enriquecidas en vacuolas se concentraron con tubos Nanosep $10 \mathrm{kDa}$. Durante la concentración de las fracciones vacuolares también se concentró gran cantidad de Ficoll y Rojo Neutro, que generaron interferencias en la cuantificación de proteínas por el método de Bradford. Debido a esto se realizó una cuantificación relativa del contenido de proteínas de las fracciones vacuolares y los extractos totales en geles SDS PAGE teñidos con Coomassie Blue (no mostrado). La identidad de las fracciones vacuolares obtenidas se constató por inmunodetección de proteínas marcadoras de vacuolas: una proteína marcadora de tonoplasto (V-ATPasa) y una proteasa residente de la vacuola (SAG2/Aleu) (Fig 2.8). Los resultados muestran claramente que la fracción vacuolar está fuertemente enriquecida en estos marcadores. 
Fig. 2.7. Protoplastos (A), y fracción vacuolar (B) de hojas senescentes de trigo.

La adición de Rojo Neutro durante la liberación de protoplastos permite visualizar las vacuolas que incorporaron este colorante, marcador de compartimientos ácidos (los protoplastos mostrados fueron separados antes del agregado de Rojo Neutro).
A) protoplastos
B) vacuolas
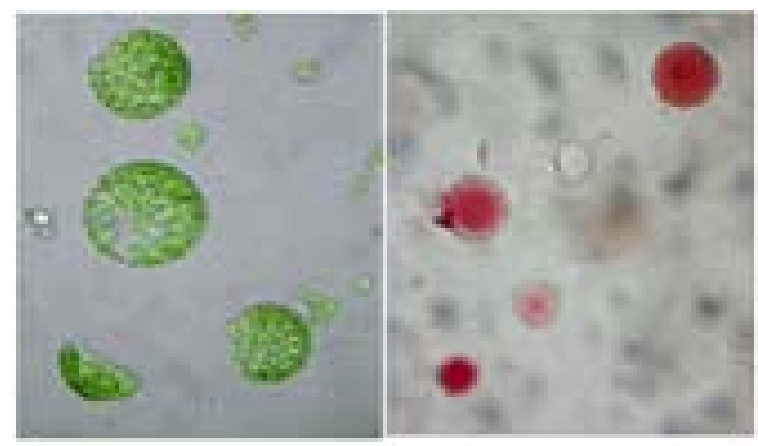

Fig. 2.8 Inmunodetección de SAG2 (A) y V-ATPasa (B). Se compararon iguales cantidades de proteína de cada fracción, medidas por densitometría de geles teñidos con Coomassie Blue. Vac=Fracción vacuolar, Ext $=$ extracto total de hojas.

A) SAG2

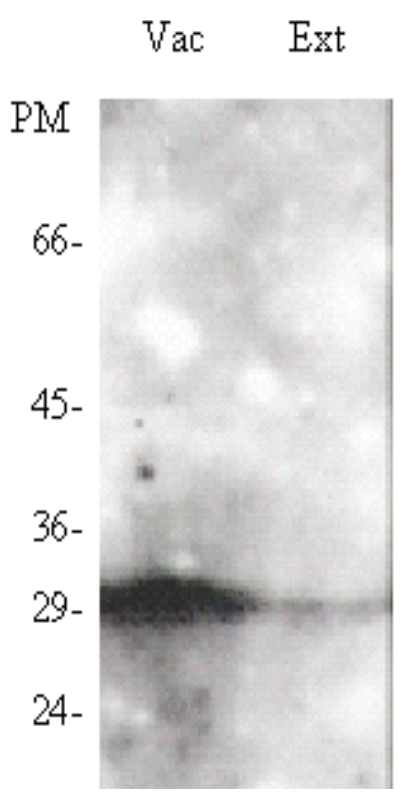

B) V-ATP asa

$\mathrm{Vac}$ Ext

PM

94-

$66-$

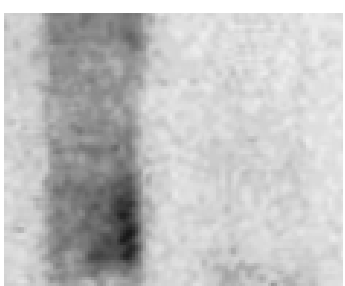

$45-$ 
2.3.4.2 Detección de proteasas cisteinicas en vacuolas a través de la marcación con DCG-04

Las fracciones enriquecidas en vacuolas y los extractos totales de hojas senescentes se marcaron con DCG-04 (Fig. 2.9). La comparación de la señal de proteasas cisteínicas de las fracciones vacuolares y los extractos totales indica que este grupo de proteasas se encuentra fuertemente enriquecido en las vacuolas de hojas senescentes, indicando que se trata proteasas vacuolares. En la misma figura se observan claramente las proteasas de 46, 39, y $36 \mathrm{KDa}$ detectadas originalmente en hojas senescentes (Fig.2.3), y otra proteasa de alrededor de $49 \mathrm{kDa}$.

Fig. 2.9. Las proteasas cisteínicas asociadas a la senescencia se concentran en vacuolas. Se comparó la marca de DCG-04 en iguales cantidades de proteína (medidas por densitometría), de fracciones vacuolares (Vac) y de extractos totales de hojas (Ext).

La tercera calle $(+)$ corresponde a un tratamiento de competición con E64, como control de la PM especificidad de la marcación. Las flechas indican señal de proteasas marcadas, de 49, 46, 39 y $36 \mathrm{kDa}$. Las cabezas de flechas indican marcación no específica (ver punto 2.2.3 de Materiales y Métodos)

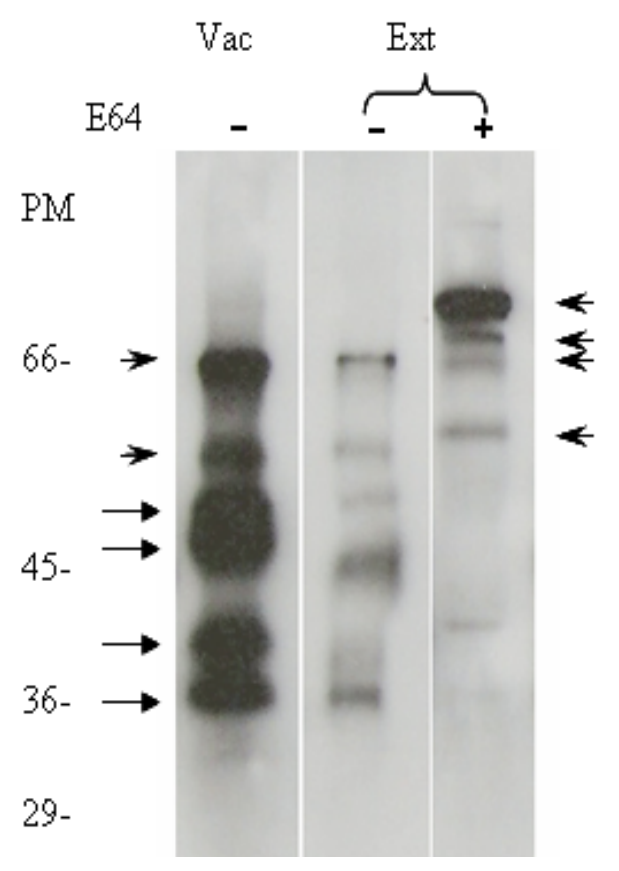




\subsubsection{Las mismas proteasas cisteínicas están asociadas a distintas situaciones que inducen o aceleran la senescencia foliar.}

Con el objetivo de discernir si las proteasas cisteínicas detectadas son parte de una respuesta específica a la inducción de la senescencia mediada por oscuridad, o bien están involucradas en el proceso de senescencia foliar independientemente del factor inductor de este proceso, se analizó la actividad de las proteasas durante la senescencia foliar promovida por déficit hídrico, o asociada a la senescencia monocárpica.

2.3.5.1. Caracterización de la senescencia foliar inducida por distintos factores. Variación del nivel de clorofila y de proteínas foliares a lo largo del tiempo.

El contenido de clorofila disminuyó de manera abrupta en hojas cortadas e incubadas en oscuridad y de forma gradual durante el transcurso de la senescencia monocárpica, en ambos casos hasta alcanzar valores no detectables por el medidor de clorofila SPAD502 (Fig. 2.10). En las plantas sometidas a déficit hídrico, en 7 días la clorofila cayó hasta un 30\% del valor inicial y se registró un valor de CRA de 67\%. Dado los errores de las mediciones realizadas con el SPAD502 en plantas bajo déficit hídrico (Martínez y Guiamét, 2004) el contenido de clorofila en este experimento se midió espectrofotométricamente, como en Inskeep y Bloom (1985). La caída de proteínas foliares en cada situación se muestra en la Fig. 2.11. En las hojas colocadas en oscuridad el nivel de proteínas totales se mantuvo constante los dos primeros días, período en el que el valor de clorofila cayó a la mitad del valor inicial. Luego, el contenido de proteínas disminuyó abruptamente durante los dos días siguientes, junto con la degradación del resto de la clorofila. El tratamiento de déficit hídrico provocó una marcada disminución en los niveles de proteínas. En cuanto a la pérdida de proteínas foliares durante la senescencia monocárpica, la frecuencia de los muestreos realizados no permiten un análisis detallado sobre la caída de proteínas foliares a lo largo del tiempo, pero es posible establecer que el momento de mayor degradación de proteínas antecedió a la caída de clorofila. 
2.3.5.2. Las proteasas asociadas a la senescencia inducida por oscuridad también están involucradas en la senescencia desencadenada por otros factores

Se realizaron zimogramas de cada una de las muestras donde se analizó el contenido de clorofila y de proteínas (Fig. 2.7). En cada situación examinada se observa el mismo perfil de actividad asociado a la senescencia foliar, detectado previamente en plantas mantenidas en oscuridad continua. Los ensayos con los inhibidores específicos y con variaciones del $\mathrm{pH}$ de incubación confirmaron que el perfil de actividad de proteasas es el mismo en cada una de las situaciones analizadas (resultados no mostrados). En los tres tratamientos inductores de la senescencia se observan las proteasas de 49, 46, 42, y $36 \mathrm{kDa}$ detectadas previamente en hojas donde la senescencia se indujo por incubación de la planta en oscuridad.

Fig. 2.10. Disminución del contenido de clorofila durante la senescencia en oscuridad (A), monocárpica (B), y por déficit hídrico (C), promedios de 8 repeticiones por tratamiento. Los valores son porcentajes del valor de clorofila inicial, registrado el primer día de oscuridad, en antesis, o al inicio del tratamiento de déficit hídrico. C, los valores de CRA fueron de $94 \%$ al inicio del tratamiento y en las plantas controles, y de $67 \%$ en plantas estresadas al final del tratamiento (promedio de tres repeticiones).

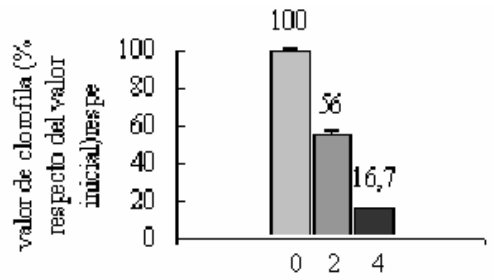

días de oscuridad

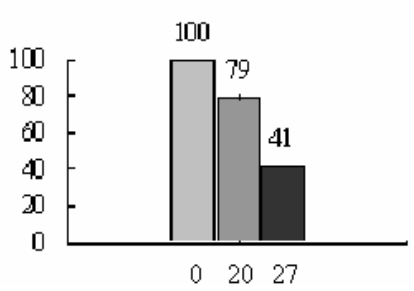

días desde antesis

B) hojas bandera de plantas a lo largo del período post antesis

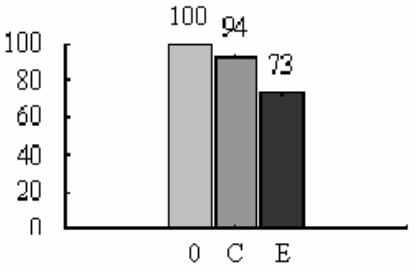

final del déficit hídrico

C) hojas de plantas sometidas a sequía. $\mathrm{C}$ y E: plantas control $\mathrm{y}$ estresadas respectivamente 
Fig. 2.11 Contenido de proteínas totales a lo largo de la senescencia foliar en las distintas situaciones analizadas. El material analizado corresponde al utilizado para las mediciones de clorofila. $\mathrm{C}=$ plantas control, $\mathrm{E}=$ plantas estresadas.

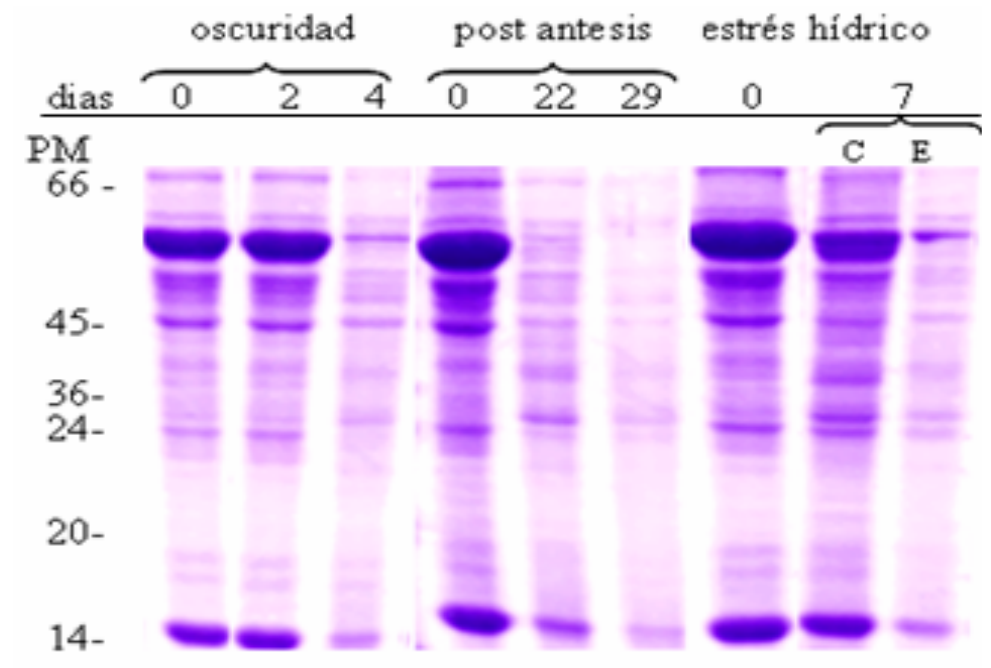

Fig. 2.12. Zimograma de los distintos tratamientos inductores de la senescencia. La incubación se realizó a $\mathrm{pH} 4 . \mathrm{C}=$ plantas control, $\mathrm{E}=$ plantas estresadas. Se analizó la actividad de proteasas de las muestras de la Fig. 2.11.

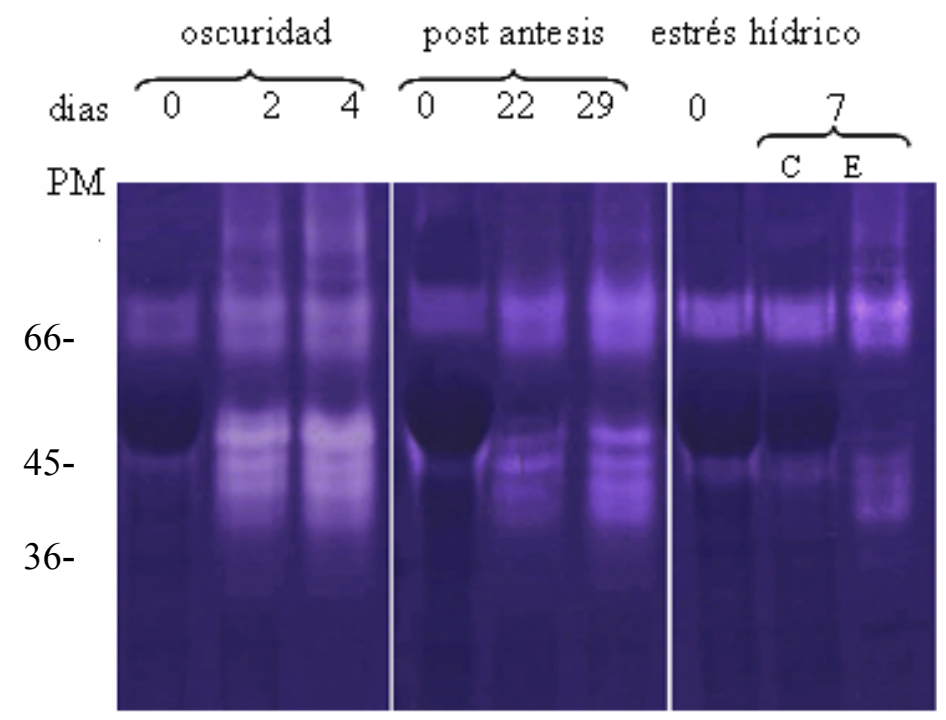




\subsection{DISCUSION}

\subsubsection{El nivel y actividad de proteasas cisteínicas aumentan durante la senescencia foliar de trigo}

La actividad proteolítica asociada a la senescencia foliar de trigo se caracteriza por la aparición y el aumento de actividad de proteasas cisteínicas. La actividad de este tipo de proteasas se estudió en primer lugar utilizando la técnica de marcado de proteasas activas por unión irreversible de un inhibidor específico biotinilado, y su posterior detección por western blot con el conjugado estreptavidina-peroxidasa (Greembaum et al., 2000). Se analizaron hojas de trigo antes y después de inducir la senescencia de toda la planta por oscuridad. Luego de tres días de tratamiento se observó el progreso de la senescencia en las hojas maduras, no senescentes al inicio de tratamiento, donde se registró una caída de un $40 \%$ de la clorofila respecto del valor inicial. En la comparación de proteasas cisteínicas de extractos totales de las hojas antes y después de inducida la senescencia, se detectó un grupo conformado por al menos cuatro proteasas cuyos niveles aumentan en las hojas senescentes. Además de un aumento en la señal de proteasas activas, en hojas senescentes aparece una proteasa de $46 \mathrm{kDa}$, y con menor señal una quinta proteasa, de alrededor de $27 \mathrm{kDa}$ (Fig. 2.3). Ligeras diferencias de movilidad relativa sugieren la aparición de otras proteasas en las muestras analizadas. La superposición en geles SDS-PAGE de proteasas marcadas debido a pesos moleculares similares, y su posterior detección con estreptavidina-peroxidasa como una única señal es un efecto observado en estudios realizados recientemente con el mismo marcador biotinilado, DCG-04, en Drosophila sp. (Kocks et al., 2003), y en Arabidopsis (van der Hoorn et al., 2004).

Los perfiles descriptos son el resultado de experimentos de marcación realizados a $\mathrm{pH} 5$, de acuerdo al $\mathrm{pH}$ de mayor actividad proteolítica registrado en extractos totales de hojas (Zagdanska y Wisnieewski, 1996) y durante la germinación de trigo (Bottari et al., 1996), y durante la senescencia foliar de otras especies como Cyperus rotundus (Fischer et al., 1998). Dado que la actividad de muchas proteasas cisteínicas es dependiente del ambiente redox en que se encuentran, la marcación de proteasas activas con DCG-04 resultaría, en mayor o menor medida, sensible al pH del medio de reacción. Sin embargo, los perfiles de actividad obtenidos a partir de 
alícuotas de una muestra marcadas con DCG-04 a distintos valores de $\mathrm{pH}$ se diferencian poco entre si, y solo se observan diferencias entre marcaciones realizadas a valores extremos de $\mathrm{pH}$ (van der Hoon et al., 2004).

\subsubsection{Las proteasas cisteínicas asociadas a la senescencia son vacuolares, y activas a pH ácido}

Además de afectar la actividad enzimática, el pH puede influir, junto a otros factores, en el mecanismo de maduración de aquellas proteasas sintetizadas como precursores o zimógenos, la remoción de propéptidos inhibidores, y en otros procesos de regulación post-traduccional de la actividad proteolítica (Wiederanders et al., 2003, Glathe et al., 1998). La proteasa cisteínica de semillas de ricino (Ricinus comunis L.) proCysEP, es activada por acidificación del compartimiento que ocupa, el ricinosoma. El cambio de $\mathrm{pH}$ causa la remoción del propeptido $\mathrm{N}$ terminal, primer paso del auto-procesamiento de esta enzima, que ocurre en pocos minutos (Schmid et al., 2001). En un estudio sobre la regulación de la actividad de la proteasa cisteínica asociada a la senescencia y el estrés hídrico, RD21, Yamada et al. (2001) demostraron que la maduración de esta enzima es mediada por otra proteasa y ocurre solo a los valores de $\mathrm{pH}$ ácido correspondientes a la vacuola central.

El efecto del $\mathrm{pH}$ sobre el perfil de actividad de las proteasas asociadas a la senescencia de trigo se analizó a través de geles de actividad (zimogramas). Mediante esta técnica las proteasas son detectadas por su actividad sobre gelatina como sustrato, luego de la separación por electroforesis en SDS-PAGE y re-naturalización de la muestra. Las actividades observadas en zimogramas realizados a distintos valores de $\mathrm{pH}$ indican que las proteasas asociadas a la senescencia son activas a $\mathrm{pH}$ ácido (Figs 2.4 y 2.5). La combinación de geles de actividad a distintos valores de $\mathrm{pH}$ con el uso de inhibidores específicos de cada tipo funcional de proteasas (cisteínicas, serínicas, aspárticas y metalo.proteasas), permitió detectar un grupo de proteasas cisteínicas cuya actividad es exclusiva de hojas senescentes (Fig 2.6a), detectable en zimogramas solo a valores de $\mathrm{pH}$ ácido menores de 5 . El número de bandas activas, su distribución en el gel y sus tamaños moleculares aproximados, sugieren que este grupo de proteasas se corresponde con el detectado previamente por marcación química con DCG-04. Las proteasas cisteínicas marcadas con DCG-04 en hojas no 
senescentes no son detectables en zimogramas. Este hecho podría deberse a que las condiciones de marcación con DGC-04 (5 h de agitación continua de la muestra, a pH 5 y temperatura ambiente) podrían resultar favorables para la maduración in vitrode las proteasas, promoviendo la activación de proteasas procesadoras de las proteasas inactivas o bien la posible activación autocatalítica de las proteasas detectadas. Otra alternativa es que la actividad de las proteasas marcadas en hojas no senescentes se encuentre por debajo de los límites de sensibilidad de los geles de actividad. En zimogramas a $\mathrm{pH}$ ácido aparece otro grupo de proteasas, formado por dos bandas cuya actividad aumenta durante la senescencia (Fig 2.4). La actividad de estas proteasas es poco sensible a cambios de $\mathrm{pH}$, aunque muestra un óptimo a $\mathrm{pH}$ 5. La inhibición de estas bandas tanto por inhibidores específicos de proteasas serínicas como de aspárticas, (Fig 2.6b) impidió la determinación inequívoca del grupo mecanístico al que pertenecen estas proteasas.

El óptimo de actividad detectado a $\mathrm{pH}$ ácido sugirió la posible ubicación vacuolar de las proteasas asociadas a la senescencia. La vacuola central es el compartimiento ácido donde se localiza la mayor parte de la actividad proteolítica asociada a procesos caracterizados por una intensa degradación de proteínas, como la muerte celular programada (Hatsugai, et al., 2004) o la formación de elementos traqueales (Funk et al., 2002). Algunas proteasas cisteínicas asociadas a la senescencia poseen señales de localización vacuolar (Kinoshita et al., 1999).

La marcación de vacuolas aisladas de trigo con DCG-04 demuestra que las proteasas citeínicas asociadas a la senescencia se localizan en la vacuola central (Fig 2.9). En fracciones enriquecidas en vacuolas se observa además una proteasa de 49 $\mathrm{kDa}$ no visible en extractos totales de hojas. La identidad de la fracción vacuolar analizada se examinó por microscopia óptica (Fig.2.7.), y se corroboró por inmunodetección con dos proteínas vacuolares, la ATPasa de tonoplasto, V-ATPase (Maeshima, 1992) y la proteasa cisteínica SAG2, homóloga a la aleuraína de cebada (Ahmed et al., 2000), componente del lumen vacuolar (Fig 2.8). La presencia de SAG2/aleuraína esta ampliamente conservada en mono y dicotiledoneas (Halls et al., 2005), y su actividad y expresión está asociada a la senescencia (Hensel. et al., 1993, Grbic, 2003). De acuerdo a su peso molecular, y a su activación a pH ácido (Howelda et al., 1990), esta proteasa podría corresponderse con una de la bandas activas observadas en los zimogramas. Si bien este trabajo se concentró en la ubicación subcelular de las proteasas cisteínicas, durante ensayos de actividad proteolítica de 
protoplastos se observa la ausencia de actividad de las proteasas de 61 y $65 \mathrm{kDa}$ (dato no mostrado), por lo que inferimos que estas dos proteasas podrían encontrarse en el espacio extracelular, al igual que la proteasa subtilisina asociada a la senescencia de trigo (Roberts et al., 2003). La activación y regulación de la actividad proteolítica asociada a la senescencia podría estar controlada por cambios de $\mathrm{pH}$ vacuolar, como ocurre con otras proteasas. La acumulación de aleuraína en las vacuolas tiene lugar junto a una disminución del pH lumenar (Holwerda et al., 1990). La actividad hidrolítica de la capa de aleurona de granos de cereales se desencadena por la acidificación dependiente de gibberellinas de las vacuolas de almacenamiento, (Swanson et al., 1998, Hwang et al., 2003). En este sentido, sería interesante contar en el futuro con mediciones del $\mathrm{pH}$ vacuolar a lo largo de la senescencia foliar, en la medida en que estos cambios podrían alterar el ritmo de degradación de proteínas en la vacuola central.

\subsubsection{Las mismas proteasas cisteínicas se activan durante la senescencia foliar natural y desencadena por distintos factores}

La exposición de hojas o plantas enteras a oscuridad ininterrumpida es un tratamiento inductor de la senescencia ampliamente utilizado en estudios de aspectos fisiológicos, moleculares y bioquímicos involucrados en este proceso (Park et al., 1998; Buchanan -Wollaston et al., 2005). Este procedimiento permite la manipulación del momento de inicio de la senescencia, y el análisis de material homogéneo. La inducción de la senescencia por oscuridad en plantas jóvenes proporciona otra ventaja en la preparación de protoplastos y vacuolas, donde características como la edad y el estado del material de partida inciden notoriamente en el rendimiento alcanzado. En contrapartida, los mecanismos que operan durante la senescencia natural y la inducida por oscuridad no son exactamente los mismos (Weaver et al., 1998; Buchanan-Wollaston et al., 2005), e incluso los efectos de la oscuridad sobre la senescencia pueden ser variables y opuestos. En Arabidopsis la senescencia se ve inducida en hojas adheridas a la planta que son individualmente sombreadas, mientras que se demora cuando toda la planta es expuesta a oscuridad (Weaver et al., 2001). El sombreado de la planta entera acelera la senescencia foliar en cebada, según indican las caídas en la eficiencia fotosintética y niveles de clorofila 
y de proteínas foliares luego de dos días oscuridad (Kleber-Janke y Krupinska, 1997). Los distintos tipos de senescencia, natural o inducida por oscuridad y otros factores parecen obedecer a distintos programas de expresión génica, con solo una fracción de genes comunes (Buchanan-Wollaston et al., 2005). Entre los SAGs que codifican proteasas cisteínicas, SAG2 es inducido en hojas de distintos estadíos ontogénicos por diversos factores, v.g. tratamientos con etileno y ABA u oscuridad, mientras que la senescencia natural es el único promotor de la expresión de SAG12 (Lohman et al., 1994). La participación diferencial de proteasas en los distintos tipos de senescencia puede observarse en perfiles de actividad proteolítica. En plantas de trébol la actividad de proteasas asociada a la senescencia difiere según esta sea natural (u ontogénica) o inducida por falta de nitrógeno (Smith et al., 2005). Miller y Huffaker (1985) encuentran claras diferencias en la actividad proteolítica asociada a la senescencia foliar cuando es natural o inducida por oscuridad, tanto en hojas cortadas como en hojas adheridas a la planta. La senescencia inducida por estrés hídrico se caracteriza por la aparición de proteasas cisteínicas no detectables durante la senescencia natural (Koizumi et al., 1993, Khanna-Chopra et al., 1999). En el presente trabajo se detectó un grupo de proteasas cuya actividad se asocia a la degradación de proteínas foliares de trigo durante la senescencia monocárpica, inducida por oscuridad o por déficit hídrico (Figs 2.11 y 2 12). Sin bien hay variación entre los niveles de proteólisis detectados en los distintos tratamientos, el efecto del pH y de inhibidores específicos indica que la actividad proteolítica detectada corresponde al mismo grupo de proteasas cisteínicas. Estas proteasas podrían estar involucradas en la ejecución del programa de senescencia operando en un mecanismo de degradación de proteínas donde convergen las respuestas "corriente abajo" de las señales específicas de los distintos factores desencadenantes del proceso.

En resumen, los experimentos de este capítulo demuestran que la actividad proteolítica asociada al proceso de senescencia foliar, considerada como una etapa normal del desarrollo ontogénico, o provocada por distintos factores, se correlaciona con el aumento de proteasas cisteínicas de localización vacuolar, cuya actividad es altamente dependiente de la acidez del medio. Los resultados concuerdan con el aumento de actividad de proteasas de procesamiento vacuolar durante la senescencia (Kinoshita et al., 1999), y con indicios de degradación extraplastidial de fragmentos de la enzima Rubisco (Zhang et al., 2005). En conjunto, las evidencias conducen a la idea de que, en parte, la degradación de proteínas durante la senescencia foliar tiene 
lugar fuera del cloroplasto, como propuso originalmente Matile (1975). En relación a esta hipótesis, se ha registrado la aparición de estructuras subcelulares asociadas a la senescencia donde, por inmunodetección, se han localizado proteínas cloroplásticas o sus productos de degradación. En Chlamydomonas, se detectaron proteínas cloroplásticas en pequeñas vacuolas por fuera del cloroplasto (Park et al., 1999). Más recientemente, Chiba et al. (2003) han registrado durante la senescencia de trigo la aparición de Rubisco o sus fragmentos de degradación en cuerpos extraplastidiales. Si bien se desconoce el origen, la función y el grado de similitud entre estas estructuras, son claras evidencias que apoyan la hipótesis de exportación de componentes cloroplásticos y su degradación extraplastidial durante la senescencia foliar. 
CAPITULO 3

Localización de actividad proteolítica in vivo e identificación de compartimientos líticos asociados a la senescencia foliar de Arabidopsis y tabaco. 


\section{RESUMEN}

Se examinó in vivo, a través de microscopía confocal, la localización subcelular de la actividad proteolítica asociada a la senescencia foliar y la localización de la proteasa cisteínica específica de la senescencia SAG12, y la naturaleza de los compartimientos que contienen a estas proteasas. Mediante el uso combinado de sustratos fluorescentes específicos de proteasas, de la proteína de fusión SAG12-GFP y de marcadores de compartimientos líticos, se detectaron pequeñas vacuolas asociadas a la senescencia (VAS) con intensa actividad proteolítica, que se desarrollan exclusivamente en células fotosintéticas durante la senescencia foliar de Arabidopsis y tabaco. Una proporción de las VAS contiene clorofila, y en plantas con expresión de la proteína fluorescente verde dirigida al cloroplasto (CP-GFP), una gran proporción de VAS contiene GFP. En experimentos de inducción acelerada de la senescencia foliar, exponiendo hojas de tabaco a etefón (un compuesto que libera etileno) y oscuridad, se observa un marcado incremento del número de VAS. Las observaciones sugieren que las VAS estarían implicadas en la degradación masiva de proteínas y otros componentes cloroplásticos durante la senescencia. La detección de actividad proteolítica y de componentes cloroplásticos en estas novedosas estructuras líticas particulares de células senescentes son claras evidencias de un mecanismo de degradación de macromoléculas asociado a la senescencia hasta el momento desconocido. 


\subsection{INTRODUCCIÓN}

Alrededor de la mitad del contenido de proteínas de una célula fotosintética se localiza en los cloroplastos, y la enzima Ribulosa bisfosfato carboxilasa/oxigenasa (Rubisco) fundamentalmente, junto al complejo recolector de luz del fotosistema II (LHCII) y otras proteínas cloroplásticas representan la fuente principal de nitrógeno removilizado durante la senescencia foliar (Hörtensteiner y Feller, 2002; Hirel y Gallais, 2006). La maquinaria proteolítica del cloroplasto comprende las proteasas necesarias para el procesamiento, la regulación y el recambio de proteínas cloroplásticas a lo largo del desarrollo (Adam y Clarke, 2002). Algunas de estas proteasas también podrían estar involucradas en la degradación masiva de proteínas cloroplásticas durante la senescencia foliar. Por ejemplo, la expresión de algunas proteasas de la familia CLP aumenta durante la senescencia (Nakabayashi et al., 1999), si bien la función de estas proteasas parece estar relacionada principalmente con la biogénesis del cloroplasto y el recambio de proteínas (Clarke et al., 2005). La inactivación de la proteasa tilacoidal AtFtsH6 impide la degradación in vitro de Lhcb3 en tilacoides aislados de hojas sometidas a alta irradiancia o a un período prolongado de oscuridad (Żelisko et al., 2005). En cloroplastos aislados incubados en oscuridad se acumula un fragmento de $44 \mathrm{kDa}$ proveniente de la degradación de la subunidad mayor de Rubisco, indicando la participación de una proteasa cloroplástica en la degradación inicial o parcial esta enzima (Kokubun et al., 2002). La proteasa cloroplástica CND41 posee actividad proteolítica in vitro sobre Rubisco y otras proteínas, aunque la unión de CND41 a ADN sugiere que la función principal de esta proteasa es más bien de tipo regulatorio (Kato et al., 2004). No hay evidencias sustanciales que demuestren la participación de proteasas cloroplásticas en la degradación masiva de proteínas asociada a la senescencia. Los experimentos de actividad proteolítica asociada a la senescencia foliar indican que las proteasas implicadas en este proceso se localizan en distintos compartimientos extraplastidiales (Palma et al., 2004; Roberts et al., 2003), fundamentalmente en la vacuola central (Capítulo 2 de esta Tesis, Miller y Huffaker, 1985, Feller y Fisher, 1994). La vacuola central (VC) es el mayor compartimiento lítico de la célula (De, 2000), está involucrada en la degradación de diversos componentes celulares y extracelulares 
(Battey et al., 1999; Barrieu y Chrispeels, 1999), y las vías de degradación autofágica convergen en esta organela (Contento et al., 2005; Thomson y Vierstra, 2005). El catabolismo de la clorofila comienza en el cloroplasto y culmina en la VC, hacia donde son transportados los catabolitos fluorescentes de la clorofila (FCCs, Matile et al., 1988).

Una misma célula puede contener distintos tipos de vacuolas, distinguibles entre sí de acuerdo a la composición lumenal y/o del tonoplasto (Paris et al., 1996; Bethke y Jones, 2000). Por ejemplo, la ATPasa vacuolar ACA4 de Arabidopsis se distribuye en pequeñas vacuolas periféricas, y está ausente en la VC (Geisler et al., 2000). En células del mesófilo de tabaco, la quitinasa se localiza en una gran vacuola central de $\mathrm{pH}$ neutro, mientras que la proteasa aleuraína se encuentra en pequeñas vacuolas líticas (Di SanSebastiano et al., 2001). La diversidad de composiciones y contenidos refleja funciones particulares para cada tipo de vacuola. En Mesembryanthemun crystalinum L. además de la vacuola ácida implicada en el metabolismo ácido de las Crasulaceas, durante situaciones de estrés salino se desarrolla un segundo tipo de vacuola cuya función principal es la acumulación de $\mathrm{NaCl}$ (Epimashko et al., 2004). Además de la VC, se han detectado otros compartimientos líticos componentes del sistema de secreción particulares de distintos procesos de proteólisis masiva. Los ricinosomas son estructuras de alrededor de $0,5 \mu \mathrm{m}$ que se originan en el endosperma de semillas de Ricinus communis, y que concentran la proteasa cisteínica CysEP (Schmid et al., 1999). La presencia de la secuencia KDEL (señal de retención en retículo endoplásmico (RE)) en la proteasa CysEP sugiere que los ricinosomas podrían originarse directamente a partir del RE. La desintegración de los ricinosomas y liberación de la proteasa CysEP conduce a la degradación del endosperma durante la germinación (Schmid et al., 2001). Estructuras similares a los ricinosomas se han encontrado durante la senescencia de pétalos de Hemerocallis sp. (Schmid et al., 2001). En cotiledones de Vigna mungo, vesículas de 0,3 $\mu \mathrm{m}$ conteniendo la proteasa cisteínica SH-EP se fusionan con vacuolas de almacenamiento, desencadenando la removilización de las proteínas de reserva (Toyooka et al., 2000).

La ocurrencia de estructuras líticas específicas (i.e., cuerpos derivados del RE, vesículas) y/o la participación de la vacuola central, y la predominancia de proteasas de tipo cisteínicas son rasgos comunes de distintos procesos de removilización masiva de proteínas en células vegetales (Galili, 2004). Un mecanismo con estas 
características podría estar operando en la degradación de proteínas cloroplásticas asociada a la senescencia. Hörtensteiner y Feller (2002) plantean modelos alternativos de degradación plastídica asociada a la senescencia foliar. Entre estos modelos se considera la participación de vesículas transportadoras de componentes cloroplásticos hacia la VC como una vía de degradación de proteínas, común o similar a la vía de degradación de la clorofila. La detección de plastoglóbulos con clorofila saliendo de cloroplastos durante la senescencia (Guiamét et al., 1999), la existencia de una isoenzima extraplastidial de clorofilasa (Tsuchiya et al., 1999), implicada en la primer reacción de la degradación de clorofila, y la acumulación vacuolar de los catabolitos finales no fluorescentes de la clorofila (NFCCs, Matile et al., 1999), sustentan la existencia de mecanismos de degradación extraplastidial de la clorofila durante la senescencia. Las evidencias de exportación y posterior degradación extraplastidial de proteínas cloroplásticas durante la senescencia se apoyan en análisis de inmunolocalización de proteínas cloroplásticas (i.e., Rubisco, LHCII) por fuera del cloroplasto (Park et al., 1999; Chiba et al., 2003), y en el hecho de que la actividad proteolítica asociada a la senescencia corresponde a proteasas de ubicación extraplastidial. La mayoría de las proteasas de tipo cisteínicas, el grupo mecanístico más representativo de la senescencia (Grudkowska y Zagdańska, 2004; BuchananWollaston et al., 2005), son direccionadas a la vía secretoria (Beers et al., 2003), y muchas de ellas tienen localización vacuolar (Kinoshita et al., 1999). Entre los genes que codifican proteasas cisteínicas, SAG12 es considerado "diagnóstico" de la senescencia foliar (Lohman et al., 1994; Weaver et al., 1998; Grbic, 2003), debido a que este gen se expresa específicamente durante la senescencia foliar natural (Lohman et al.,1994), y no es inducido por ningún otro factor que acelere este proceso (Weaver et al., 1998). La proteasa sag12 posee una señal de direccionamiento a la vía secretoria (Lohman et al., 1994), aunque su localización subcelular se desconoce.

En conjunto, las evidencias sugieren que el confinamiento de proteasas en compartimiento/s extraplastidiales podría jugar un papel importante en la regulación de la degradación de proteínas cloroplásticas durante la senescencia. La persistencia de la compartimentalización subcelular hasta una etapa avanzada en la degradación de componentes cloroplásticos, un rasgo propio de la senescencia (Peoples et al., 1980), excluye la posibilidad de que las proteínas cloroplásticas resultaran expuestas y vulnerables a ser degradadas por proteasas liberadas desde otros compartimientos. 
El trabajo presentado a continuación corresponde al estudio in vivo, a través de microscopía laser confocal de la localización subcelular de la actividad proteolítica y la identificación de compartimientos líticos asociados a la senescencia foliar. El objetivo principal fue establecer el sitio de degradación de proteínas durante la senescencia y la relación entre la degradación de proteínas cloroplásticas asociada a la senescencia y la actividad de proteasas vacuolares y/o de otras ubicaciones extraplastidiales. Además, de acuerdo con la hipótesis general planteada en esta Tesis sobre la degradación masiva de proteínas del cloroplasto fuera de esta organela, se examinaron posibles cambios durante la senescencia en la ubicación subcelular de una proteína con un péptido de tránsito al cloroplasto, es decir se determinó si las proteínas cloroplásticas pueden ser re-localizadas a otras organelas para su degradación fuera del cloroplasto.

\subsection{MATERIALES Y MÉTODOS}

\subsubsection{Material vegetal y condiciones de cultivo}

Para estos experimentos se utilizaron Arabidopsis thaliana y tabaco (Nicotiana tabacum L.).

Arabidopsis: Se utilizaron plantas de Arabidopsis thaliana ecotipo Wassilewskija de genotipos salvaje, mutantes por inserción de ADN de transferencia (TDNA) para el gen SAG12 ( $\operatorname{sag} 12-2)$, y líneas donde la proteasa sag12 está fusionada a la proteína fluorescente verde (Pro $\left.{ }_{\mathrm{SAG} 12}: \mathrm{SAG} 12-\mathrm{GFP}\right)$. La construcción Pro $_{\mathrm{SAG} 12}:$ SAG12-GFP (abreviada SAG12-GFP) y la obtención de la línea mutante para SAG12 (sag12-2) fue realizada por el Dr. Amasino (Universidad de Wisconsin, USA) en colaboración con nuestro grupo de trabajo. Las características de estas líneas y parte de los resultados presentados de este Capítulo han sido publicados (Otegui et al., 2005). 
Pro $_{S A G 12}: S A G 12-G F P:$ La secuencia completa de SAG12, amplificada por PCR a partir de ADN genómico, fue fusionada a GFP insertando un adaptador (IAG) entre el codón de finalización de SAG12 y el codón de inicio de GFP. SAG12-GFP se introdujo en Agrobacterium tumefaciens, para transformar Arabidopsis por infiltración. Las líneas transformadas se seleccionaron por su resistencia a gentamicina.

sag12-2: Esta línea pertenece a la colección de mutantes de Arabidopsis de la Universidad de Wisconsin (http://www.biotech.wisc.edu/Arabidopsis/ ). La colección fue generada por inserción de TDNA y es resistente a kanamicina. sag12-2 se aisló por PCR y se seleccionó por resistencia al antibiótico. sag12-2 posee un solo inserto de TDNA en el segundo exón del gen SAG12.

Las plantas se cultivaron en macetas con una mezcla de tierra estéril y perlita. Después de dos días en oscuridad a $4^{\circ} \mathrm{C}$, las macetas se trasladaron a cámaras de crecimiento a $24^{\circ} \mathrm{C}$, a un PFFD de $80 \mu \mathrm{mol} \mathrm{m} \mathrm{m}^{-2}, 11$ horas luz/ $13 \mathrm{~h}$ oscuridad.

Tabaco: Se utilizaron plantas de Nicotiana tabacum L. cv. Xanthi NN salvajes, y plantas del cv. Petit Havana que expresan GFP direccionada al cloroplasto (CP-GFP), estas últimas líneas fueron cedidas por la Dra. M. Hanson (Universidad de Cornell, USA). La construcción CP-GFP corresponde a la fusión de GFP (S65T) con el péptido de tránsito del gen recA de Arabidopsis, y el promotor 35S:35S (Köhler et at., 1997). Las plantas fueron cultivadas en macetas, a $24^{\circ} \mathrm{C}$, con un PFFD de 300 $\mu \mathrm{mol} \mathrm{m} \mathrm{s}^{-2}, 10 \mathrm{~h}$ luz/ $14 \mathrm{~h}$ oscuridad.

A excepción del experimento de inducción de la senescencia foliar (punto 3.2.2, desarrollado a continuación), las plantas seleccionadas para los distintos experimentos se mantuvieron en oscuridad $12 \mathrm{~h}$ antes de su análisis.

\subsubsection{Inducción de la senescencia foliar de tabaco}


El algunos experimentos, la senescencia de hojas de tabaco se aceleró por incubación en oscuridad y tratamiento con etileno. Hojas en un estadío inicial de la senescencia se cortaron de la planta, se rociaron con fungicida (Captan, $0,5 \mathrm{~g} \mathrm{~L}^{-1}$ ) y se sumergieron durante 3 minutos en agua destilada $\left(\mathrm{dH}_{2} \mathrm{O}\right)$ con 100 ppm de etefón disuelto en $0,1 \% \mathrm{v} / \mathrm{v}$ DMSO, o en $\mathrm{dH}_{2} \mathrm{O}-0,1 \% \mathrm{v} / \mathrm{v}$ DMSO (como control), y se colocaron en oscuridad a $24^{\circ} \mathrm{C}$ por 2-3 días.

\subsubsection{Medición de clorofila foliar y almacenamiento de muestras}

La clorofila foliar se midió de forma no destructiva con el SPAD 502, como en el Capítulo 2. El material utilizado para análisis de proteínas (punto 3.2.6 de esta sección) se congeló en nitrógeno líquido y se almacenó a $-80^{\circ} \mathrm{C}$ hasta su utilización.

\subsubsection{Producción de células y protoplastos}

Se prepararon protoplastos de Arabidopsis como en el Capítulo 2 de esta Tesis, con ligeras modificaciones. Los trozos de tejido, de alrededor de $1 \mathrm{~mm}^{2}$, se sometieron a digestión en MES $20 \mathrm{mM}, \mathrm{pH}$ 5,8, manitol0,5M, 1\% celulasa, 0,3\% pectinasa, $0,3 \%$ driselasa, durante dos horas. Luego se filtraron a través de una malla de $10 \mu \mathrm{m}$, se lavaron con buffer MES $20 \mathrm{mM}$, manitol 0,5M sin enzimas de digestión, y se colectaron por centrifugación a $50 \mathrm{~g}$ durante 15 minutos. Las células de tabaco se prepararon de la misma manera, aunque utilizando como buffer de digestión MES 25 $\mathrm{mM}, \mathrm{pH} 5,5$, betaína $0,45 \mathrm{M}, 0,3 \%$ pectoliasa.

\subsubsection{Análisis por microscopía confocal. Fluorocromos y condiciones experimentales}




\subsubsection{Sustratos fluorescentes y fluorocromos}

Se utilizaron sustratos específicos de proteasas cisteínicas (R6502, rodamina 110, bis-CBZ-L-fenilalanil-L-arginina), y serínicas (R6505, rodamina 110, bis-CBZL-isoleucil-L-prolil-L-arginina). Estos sustratos son no-fluorescentes, pero el producto de degradación por acción de peptidasas (i.e., rodamina) es altamente fluorescente (la acción de peptidasas incrementa el rendimiento cuántico de la fluorescencia en varios órdenes de magnitud, Molecular Probes- HandBook, www.probes.com). La marcación de compartimientos ácidos se realizó con Lysotracker Red y Rojo Neutro. Estos fluorocromos penetran libremente al interior celular pero al adquirir carga positiva resultan impermeables a las membranas celulares, acumulándose en el/los compartimientos ácidos donde se protonan (Molecular Probes Handbook, www.probes.com). Los sustratos de proteasas y los marcadores de compartimientos ácidos se diluyeron a una concentración final de 50 $\mu$ molar y $5 \mu$ molar, respectivamente, en buffer $25 \mathrm{mM}$ MES pH 6,0, inmediatamente antes de la incubación de las muestras. El tiempo de incubación de las muestras con los fluorocromos fue variable dependiendo del material analizado, entre 20 min. para protoplastos, a $1 \mathrm{~h}$ para trozos de tejido. Los sustratos de proteasas se utilizaron en células y protoplastos, para facilitar su incorporación celular y al mismo tiempo evitar su degradación por proteasas extracelulares, presentes en los trozos de tejido. Los productos R6502, R6505 y Lysotracker Red se adquirieron en Molecular Probes Inc (Eugene, OR, USA).

\subsubsection{Microscopía confocal}

Las muestras se observaron por microscopía laser confocal con un microscopio LSM 510, LSM510 META o LSM Pascal (Carl Zeiss Inc.). Las condiciones de excitación (ex) y emisión (em) fueron: ex. 488nm/ em. 505-530nm para GFP, R6502 y R6505; ex. 543nm/ em.585-615nm para Lysotracker Red y Rojo Neutro; y ex. $633 \mathrm{~nm} / \mathrm{em}$ 670-730 nm para clorofila. Previo al desarrollo de los experimentos se efectuaron los siguientes controles: 1- en plantas de Arabidopsis y de tabaco de genotipo salvaje (es decir, que no expresan GFP) y sin tratar con ningún fluorocromo se midió la fluorescencia de base (autofluorescencia) para cada configuración. 2- Para descartar que la señal correspondiente a GFP, R6502 o R6505 se extendiera a la banda utilizada para detectar Lysotracker Red o Rojo Neutro, se 
determinó la emisión a 585-615nm de líneas expresando GFP, o en líneas salvajes incubadas con R6502 o R6506. 3- Para descartar que la señal correspondiente a Lysotracker Red o Rojo Neutro se extendiera a la banda utilizada para detectar GFP, R6502 o R6505, se determinó la emisión a 505-530nm de líneas salvajes incubadas con Lysotracker Red o Rojo Neutro. Estos controles permitieron corroborar que las señales en cada banda correspondían específicamente a cada fluorocromo utilizado o a GFP.

A través del detector META, con el programa "Lambda Mode", se analizó el espectro de emisión de fluorescencia de GFP y clorofila en el rango de emisión 494558 (GFP) y 650-730 nm (clorofila). Se tomaron los espectros de emisión de fluorescencia ("Emission Fingerprint") de distintos puntos en el espacio $x y$ de una misma sección óptica $(z)$. Las imágenes se adquirieron con el programa Zeiss LSM Image Examiner y se importaron al programa Adobe Photoshop 6.0.1 (Mountain View, CA, USA).

\subsubsection{Perfil de proteínas e inmunodetección de GFP por Western Blot}

Las hojas de tabaco se homogeneizaron en 50 mM HEPES, 1 mM EDTA, 1 $\mathrm{mM}$ PMSF, $20 \mu \mathrm{M}$ E64, 0,1\% albúmina de suero bovino, 1\% PVPP, se centrifugaron a $10000 \mathrm{~g}$ durante 15 minutos y el sobrenadante se mezcló con buffer de solubilización 2X (Laemmli 1970). Las muestras se separaron en geles SDS PAGE que se tiñeron con Coomassie Blue, o se electrotransfirieron a membranas de nitrocelulosa, como en el Capítulo 2, punto 2.2.3 de esta Tesis. GFP se detectó con un anticuerpo comercial (Molecular Probes Inc Eugene, OR, USA), diluído 1:1000 v/v,

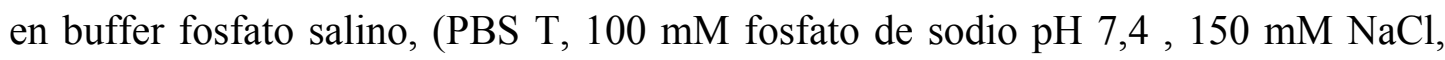
$0,05 \%$ Tween 20 ) con $10 \%$ de leche descremada marca SER.

\subsection{RESULTADOS}

La microscopía confocal permite realizar estudios in vivo de la localización subcelular de proteínas y, utilizando fluorocromos apropiados, de la localización de 
distintos procesos fisiológicos. En este Capítulo se utilizaron Arabidopsis y tabaco debido a la disponibilidad de las construcciones SAG12-GFP y CP-GFP, de vital importancia en el presente estudio, en estas especies. Al igual que en el Capítulo 2, la determinación del grado de senescencia foliar en estas especies se realizó en función del contenido de clorofila, en hojas completamente expandidas.

\subsubsection{Una población de pequeños compartimientos ácidos con actividad proteolítica en hojas senescentes}

Se examinó la localización subcelular de la actividad proteolítica asociada a la senescencia foliar de Arabidopsis. Para esto se incubaron protoplastos de hojas no senescentes (NS) y senescentes (S, 50-75\% de la clorofila respecto del NS) con el sustrato de proteasas cisteínicas R6502. La señal de degradación de R6502 (es decir, la actividad de peptidasas) se observa como un "punteado" en las hojas senescentes, que no es visible en hojas no senescentes (Fig 3.1 A y B) examinadas en idénticas condiciones de intensidad de excitación y ganancia del detector confocal. Estos "puntos" son pequeñas estructuras, de alrededor de $1,0 \mu \mathrm{m}$ de diámetro, de distribución cortical en la célula. Con menor intensidad, se alcanza a detectar hidrólisis de R6502 en la vacuola central de protoplastos de hojas senescentes y no senescentes (datos no mostrados). Para establecer la naturaleza de las estructuras detectadas en los protoplastos de hojas senescentes, se incubaron muestras con R6502 y con los indicadores de compartimientos ácidos Lysotracker Red o Rojo Neutro, utilizados habitualmente como marcadores de lisosomas y vacuolas (Di SanSebastiano et al., 2001; Toyooka et al., 2001). La mayor señal de Lysotracker Red y Rojo Neutro también se observó en pequeñas estructuras, y colocalizó con la señal de hidrólisis de R6502 (Fig. 3.1 B, C y D). Estas pequeñas estructuras marcadas por Lysotracker Red o Rojo Neutro no son detectables en hojas no-senescentes (Fig. 3.1.C). Estos resultados indican que la principal actividad de proteasas cisteínicas durante la senescencia foliar se concentra en pequeños compartimientos ácidos de naturaleza vacuolar, no detectables en células no senescentes, y cuya aparición se asocia estrechamente a la senescencia foliar. Denominamos "VAS" a estas pequeñas vacuolas asociadas a la senescencia. 
SAG12 ("senescence-asociated gene” 12) codifica un proteasa cisteínica (Lohman et al., 1994), y es el único gen identificado hasta el momento cuya expresión es detectable exclusivamente en hojas durante la senescencia foliar (Lohman et al., 1994; Weaver et al., 1998). Consistentemente con estas observaciones, la expresión de la fusión SAG12-GFP sólo se observó en hojas senescentes, y se localizó en pequeñas estructuras marcadas con Lysotracker Red y/o Rojo Neutro (Fig 3.2). La colocalización de SAG12-GFP con los marcadores de VAS, Lysotracker Red y/o Rojo Neutro, y su distribución subcelular, similar a la observada con R6502, indican que SAG12-GFP se concentra en las VAS. Para determinar si la actividad proteolítica detectada en la VAS es debida exclusivamente a la presencia de SAG12, se incubaron protoplastos de plantas mutantes knock out para SAG12 (sag12-2) con R6502. En los protoplastos de hojas senescentes de sag12-2 se observó el mismo patrón de fluorescencia de R6502 y Lysotracker Red observado en plantas salvajes (resultados no mostrados). Este resultado indica que las VAS contienen otra/s proteasa/s de tipo cisteínica/s además de la proteasa SAG12 .

\subsubsection{La distribución tisular de VAS se restringe a células fotosintéticas}

Las VAS fueron detectadas durante la senescencia foliar en células con cloroplastos. Para determinar si la distribución de VAS está limitada a un determinado tipo celular y/o localización tisular se realizaron cortes transversales, a mano alzada, de hojas senescentes de Arabidopsis. En la Fig. 3.3 se observa la presencia de VAS, marcadas con Lysotracker Red, exclusivamente en las células fotosintéticas del mesófilo, mientras que en la epidermis solo se detectan VAS en las células oclusivas, el único tipo de célula epidérmica que posee cloroplastos. 
Fig. 3.1. La actividad de proteasas cisteínicas de hojas senescentes se concentra en pequeñas vacuolas a asociadas a la senescencia (VASs)

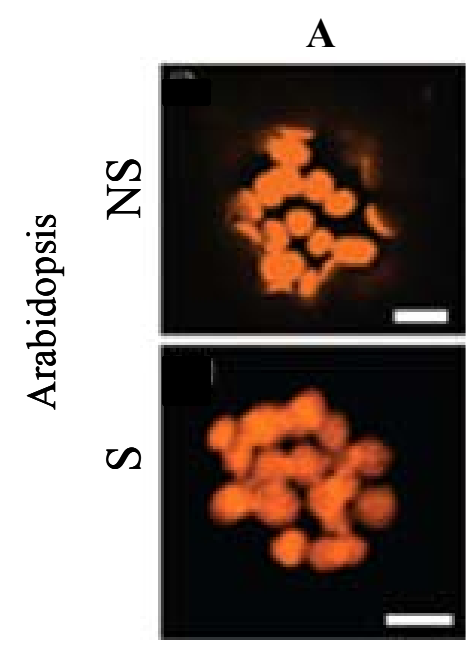

Clorofila

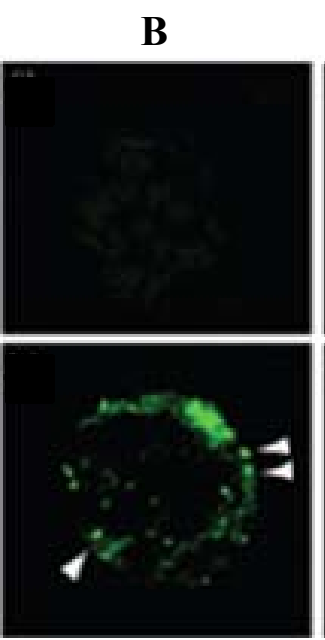

R6502

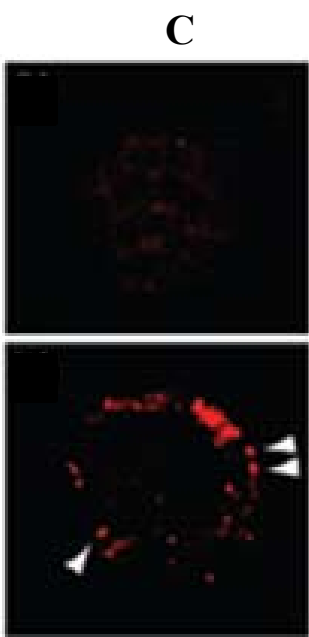

Rojo Neutro

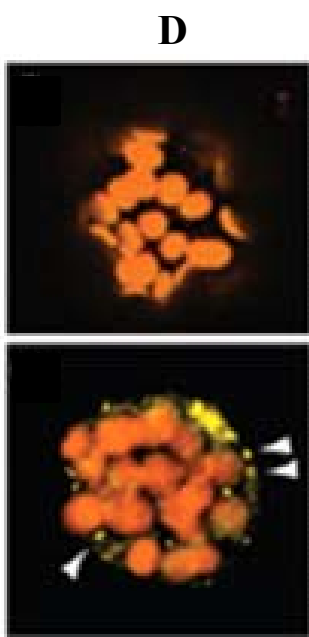

Superposición de señales

Protoplastos de hojas senescentes (S) y no senescentes (NS) de Arabidopsis se incubaron con el sustrato de proteasas R6502, y el marcador de compartimientos ácidos, Rojo Neutro. Las flechas indican compartimientos con actividad proteolítica (paneles B), y de interior ácido (paneles C), y en D las flechas indican la colocalización de ambos fluorocromos (en color amarillo). Barra de escala $=10$ $\mu \mathrm{m}$. 
Fig. 3.2 Localización de SAG12-GFP en células del mesófilo de hojas senescentes de Arabidopsis.

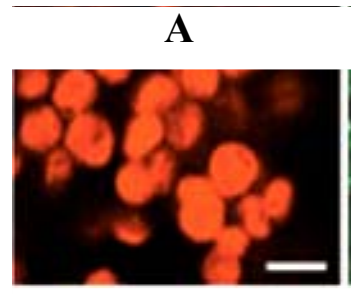

Clorofila

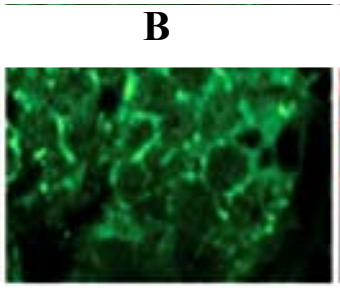

SAG12-GFP

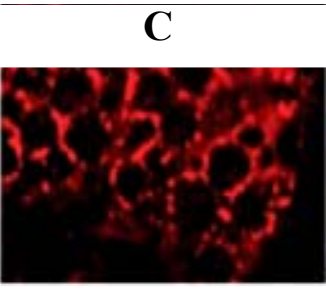

Rojo Neutro

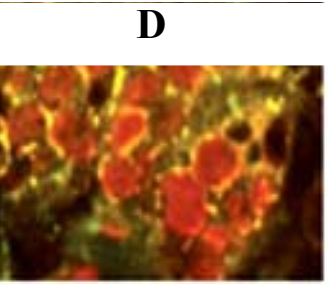

Superposición de señales

Trozos de hojas senescentes de Arabidopsis con expresión de SAG12-GFP se incubaron con Rojo Neutro. La proteasa sag12 se observa como un "punteado" que colocaliza con el marcador de VAS, Rojo Neutro. La colocalización se observa en color amarillo, en el panel D. Barra de escala $10 \mu \mathrm{m}$. 
Fig. 3. 3 Distribución de las vacuolas asociadas a la senescencia (VAS) en hojas senescentes de Arabidopsis.
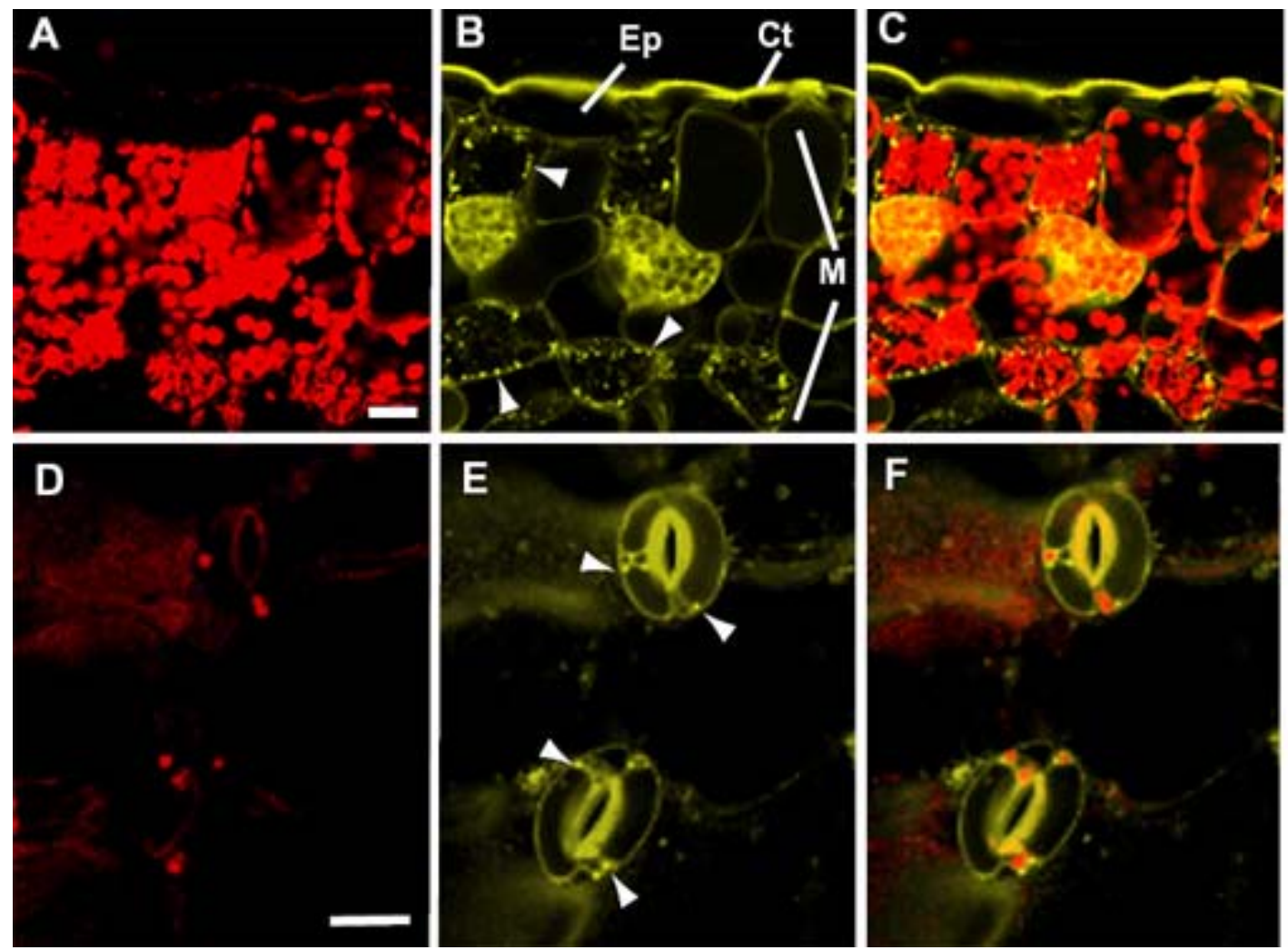

Clorofila

Lysotracker

Superposición de imágenes

Trozos de hojas senescentes de Arabidopsis se incubaron con el marcador de compartimientos ácidos Lysotracker Red. A-C: Corte transversal .Ep: epidermis, Ct: cutícula, M: células del mesófilo. D-F Imagen de la epidermis, donde las VAS solo se localizan en las células oclusivas del estoma. B y E: La presencia de VAS, evidenciada por Lysotracker Red, se indica con flechas. La cutícula y la cara interna de las células oclusiva presentan gran autofluorescencia. Escala $20 \mu \mathrm{m}$. 


\subsubsection{Las VAS están involucradas en la degradación de componentes cloroplásticos}

La actividad de proteasas cisteínicas asociada a la senescencia foliar de Arabidopsis se concentra en pequeñas estructuras de naturaleza vacuolar (VAS) cuya aparición es característica de la senescencia, y, en las hojas senescentes, es exclusiva de las células fotosintéticas. Estas observaciones condujeron a la hipótesis de que las VAS podrían estar implicadas en la degradación masiva de proteínas cloroplásticas asociada a la senescencia foliar. Una predicción de esta hipótesis es que las proteínas cloroplásticas degradadas durante la senescencia deberían ser previamente relocalizadas a las VAS.

Para este estudio se utilizaron líneas de tabaco con expresión de GFP direccionada a cloroplasto. La proteína de fusión CP-GFP resultó adecuada para este fin dado que: 1- en hojas no senescentes la expresión de CP-GFP se observa exclusivamente en los cloroplastos (Kwok y Hanson, 2004, Fig. 3.4), y 2- el nivel estable de CP-GFP disminuye durante la senescencia foliar con un ritmo similar al observado en la mayoría de las proteínas cloroplásticas y Rubisco (Fig. 3.5).

Fig. 3.4. Expresión de CP-GFP en hojas no senescentes de tabaco.

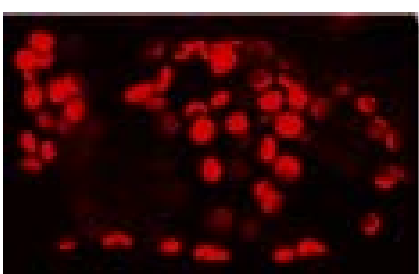

Clorofila

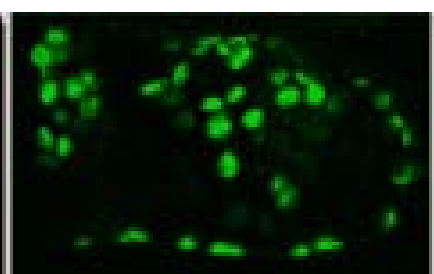

CP-GFP

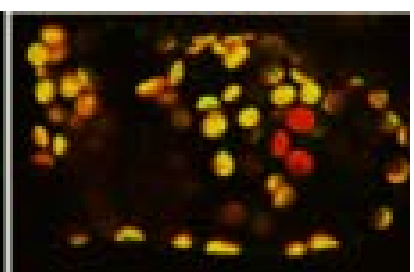

Superposición de imágenes 
La señal de CP-GFP se observa exclusivamente en los cloroplastos en las células del mesófilo de hojas no senescentes.

Fig. 3.5. Niveles estables de CP-GFP durante el progreso de la senescencia foliar

A) Perfil de proteínas totales

Progreso de la senescencia

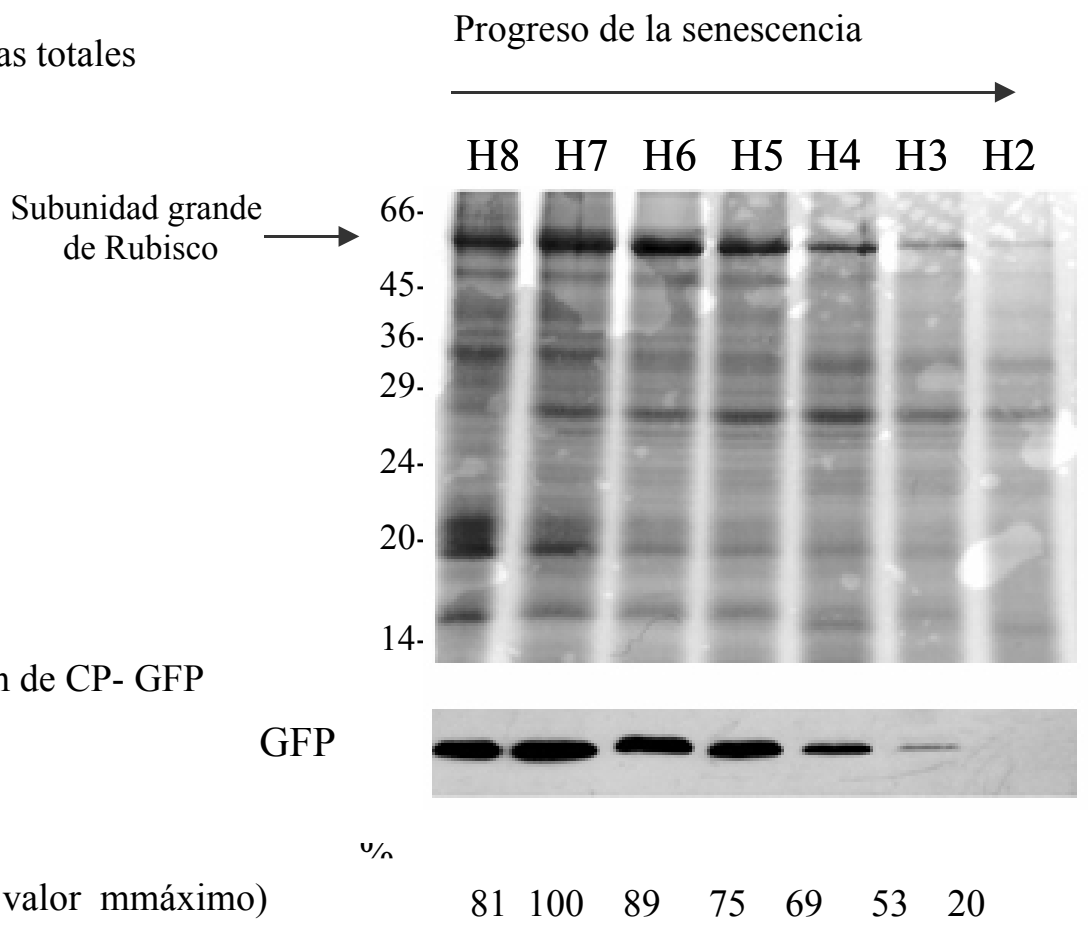

B) Inmunodetección de CP- GFP

C) Clorofila (\% del valor mmáximo)

$\begin{array}{lllllll}81 & 100 & 89 & 75 & 69 & 53 & 20\end{array}$

La disminución del nivel estable de GFP acompaña la caída asociada a la senescencia foliar de la clorofila y la mayor parte de las proteínas. Muestras H8 a H2: hojas de la planta de tabaco numeradas desde el ápice a la base. H8 corresponde a la hoja más jóven, todavía en crecimiento; H2 la segunda hoja más senescente (no se detectaron proteínas ni señal de GFP en $\mathrm{H1}$ ).

A-perfil de proteínas totales en geles SDS-PAGE teñidos con Coomassie Blue, B- inmunodetección de CP-GFP en Western Blot y C-variación porcentual en el contenido de clorofila. 


\subsubsection{Vacuolas Asociadas a la Senescencia en tabaco}

Durante el transcurso de la senescencia foliar de plantas salvajes de tabaco se detectó la aparición de pequeñas estructuras, marcadas con Lysotracker Red y/o Rojo Neutro, de tamaño (alrededor de 1,0 $\mu \mathrm{m}$ ) y distribución similar a las encontradas previamente en Arabidopsis (Fig. 3.6). En células de hojas senescentes de tabaco la señal de hidrólisis del sustrato de proteasas cisteínicas R6502 colocalizó con los pequeños compartimientos ácidos (Fig.3.7a). Por su aparición asociada al desarrollo de la senescencia, tamaño, distribución, acidez y actividad proteolítica, estas estructuras se corresponden con las VAS descriptas previamente en Arabidopsis. En plantas de tabaco también se analizó la actividad asociada a la senescencia de proteasas de tipo serínicas. Luego de la incubación de células de hojas senescentes con el sustrato de proteasas serínicas R6505, la mayor parte de la actividad proteolítica colocalizó con Lysotracker Red y/o Rojo Neutro, indicando la acumulación de este tipo de proteasas en las VAS (Fig. 3.7b).

Fig. 3.6 Pequeñas vacuolas asociadas a la senescencia foliar (VAS) se observan en células fotosintéticas de tabaco.

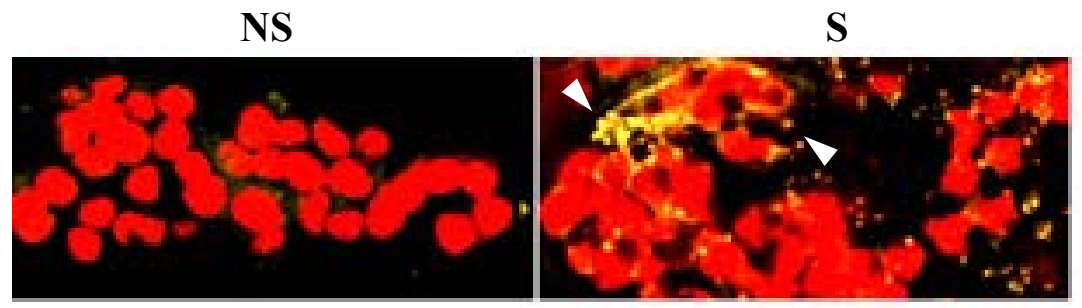

Imágenes superpuestas de clorofila y Lysotracker Red

Células de hojas de tabaco no senescentes (NS) y senescentes (S, con el 50- $75 \%$ de la clorofila respecto de NS), se incubaron con el marcador de compartimientos ácidos Lysotracker Red. En rojo se muestra la clorofila, en amarillo la señal de Lysotracker Red. Las flechas indican la presencia de VAS en la célula senescente. 
Fig. 3.7 Las vacuolas asociadas a la senescencia foliar de tabaco concentran la mayor actividad proteolítica de la célula.
A
B
C
D

a)

b)

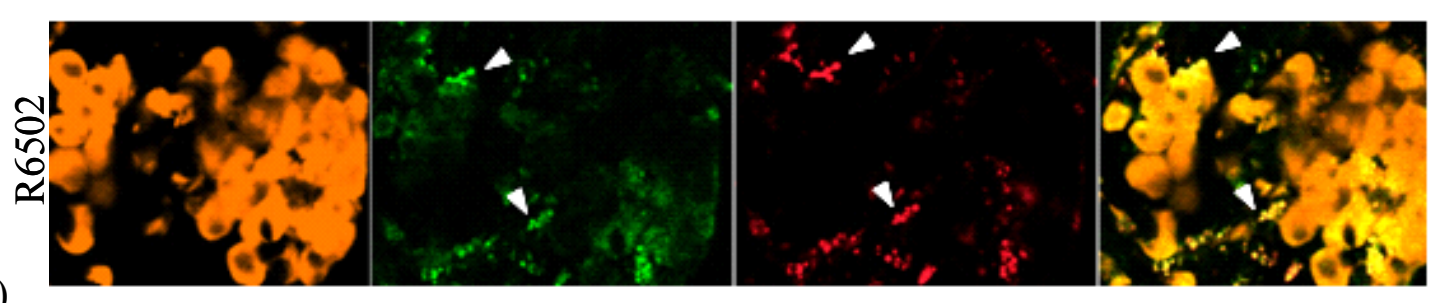

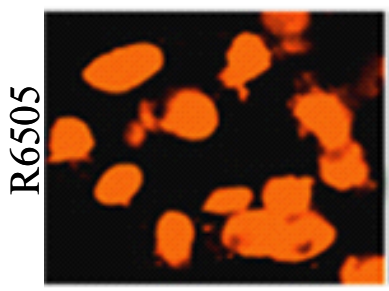

Clorofila

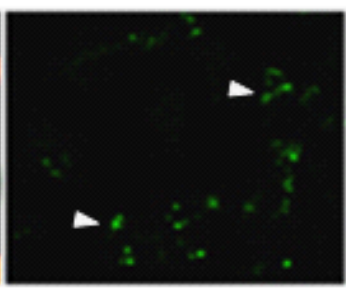

Actividad proteolítica

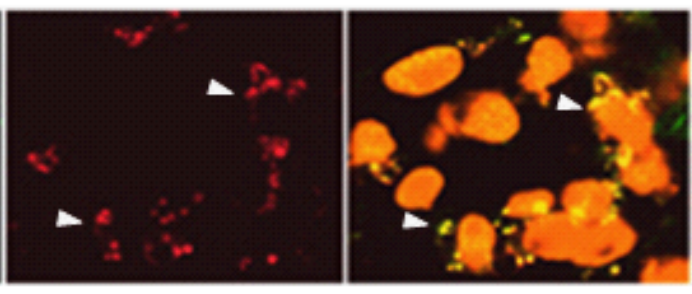

LysoTracker Red

Superposición de imágenes

Células de hojas senescentes de tabaco se incubaron con el marcador de compartimientos ácidos LysoTracker Red, y el sustrato de proteasas tipo cisteínicas, R6502, o tipo serínicas R6505. Las flechas indican compartimientos con actividad proteolítica (paneles B), y de interior ácido (paneles C), y en D la colocalización del patrón de fluorescencia de ambos fluorocromos (en color amarillo). 


\subsubsection{Las VAS contienen CP-GFP (GFP direccionada al cloroplasto) y clorofila (o}

catabolitos derivados de la clorofila)

Se examinó la distribución subcelular de GFP y la aparición de VAS durante la senescencia foliar de plantas de tabaco de la línea CP-GFP. La señal de CP-GFP, brillante y localizada exclusivamente en los cloroplastos en hojas no senescentes (Fig. 3.4), se atenúa en los cloroplastos de hojas senescentes, donde además GFP se observa también en pequeñas estructuras extraplastidiales (Fig. 3.8, paneles A y B). El patrón de distribución de VAS en las plantas con expresión de CP-GFP es similar al observado en plantas salvajes (Fig. 3.6), y de acuerdo a la colocalización con Lysotracker Red, una gran proporción de VAS contiene GFP (Fig. 3.8 paneles E y G). Durante la observación detallada de las distintas VAS se detectó que una fracción de estas vacuolas contiene clorofila (o algún catabolito derivado de este pigmento con emisión de fluorescencia similar, Fig. 3.8 paneles D y F). Invariablemente, las VAS con clorofila se encuentran siempre próximas a los cloroplastos. Menos frecuentes, pero observadas en forma sistemática, se detectaron VAS donde colocalizaron clorofila y GFP. El análisis seriado en el eje $z$ de secciones ópticas de $1 \mu \mathrm{m}$ a lo largo de $3 \mu \mathrm{m}$ (Fig. $3.8 \mathrm{G}-\mathrm{I}$ ) hasta $7 \mu \mathrm{m}$ (resultados no mostrados) muestra que las VAS son estructuras con independencia física de los cloroplastos (Fig. 3.8 G-I). Si bien algunas VAS se observan sumamente cercanas a los cloroplastos, no se detectó ninguna conexión física entre VAS y cloroplastos, ni prolongaciones o deformaciones de esta organela en zonas de cercanía a VAS. La identidad de las señales detectadas como GFP y clorofila en las VAS se corroboró tomando los espectros de emisión de fluorescencia de cada una de estas moléculas en las VAS y en los cloroplastos (Fig. 3.9) utilizando el detector META del LSM510. Con el nivel de resolución espectral (aproximadamente 3-4 $\mathrm{nm}$ ) del detector META los espectros de emisión en la banda correspondiente a GFP son idénticos en los cloroplastos y las VAS. También son muy similares los espectros en la banda correspondiente a clorofila, aunque la emisión de las VAS es ligeramente menor que en los cloroplastos a longitudes de onda $>692 \mathrm{~nm}$. También se detectaron VAS con clorofila en plantas de genotipo salvaje de tabaco y Arabidopsis (datos no mostrados). 
Fig. 3.8. Localización de clorofila, GFP y VAS en hojas senescentes de plantas de tabaco de la línea CP-GFP.

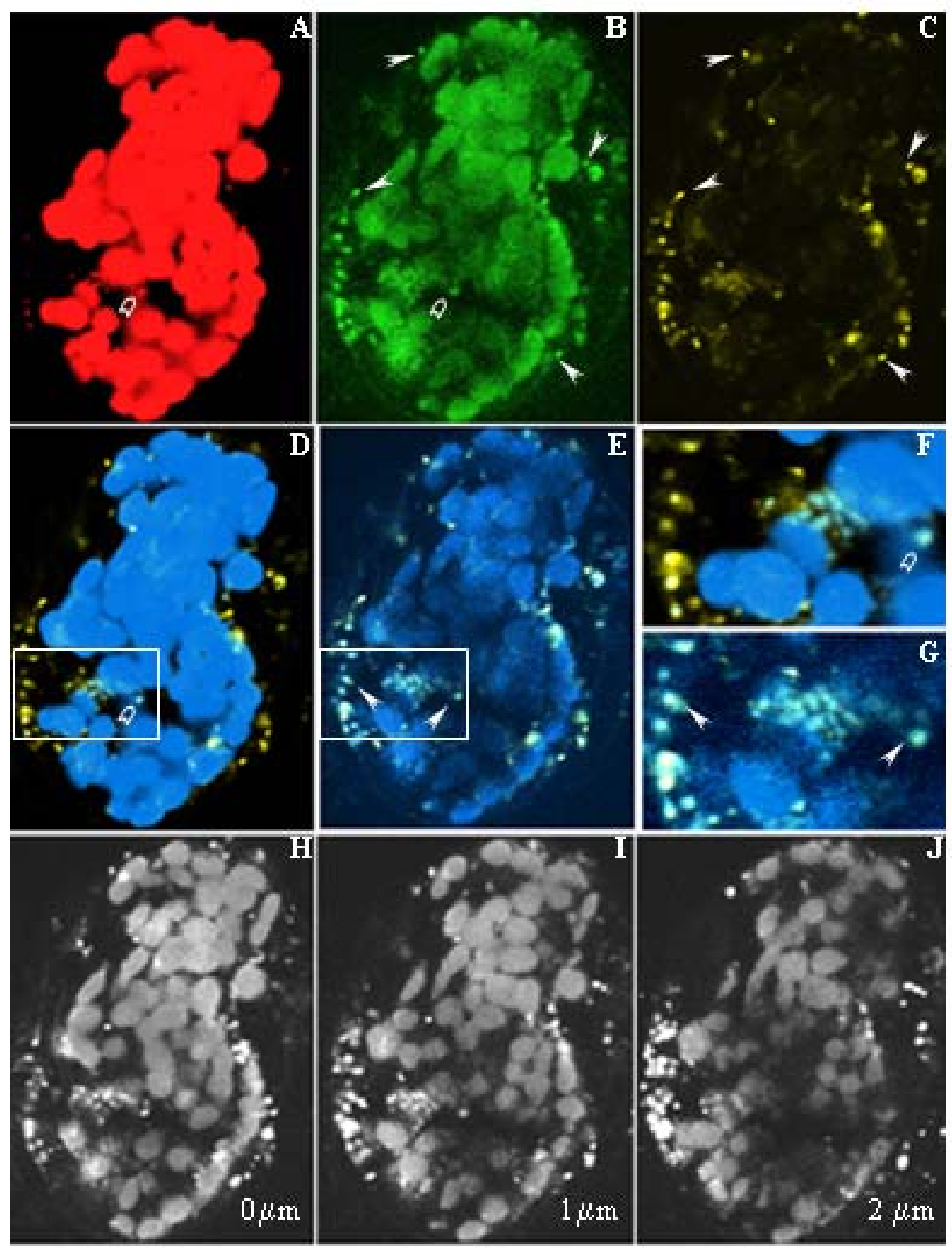

Células de hojas senescentes de plantas con expresión de CP-GFP (H4 y H5 de la Fig. 3.5), fueron incubadas con el marcador Lysotracker Red. A: clorofila, B: GFP, C: Lysotracker; D y F: clorofila (azul) y Lysotracker (amarillo); E y G: GFP (azul) y Lysotracker (amarillo). Las flechas indican VAS. Flechas cerradas indican VAS conteniendo GFP, las flechas abiertas indican VAS con GFP y clorofila. D-G: la colocalización de GFP y/o clorofila y Lysotracker se observa en celeste. H-J: Secciones ópticas seriadas a lo largo de $3 \mu \mathrm{m}$ de espesor en el eje $z$, cada sección es de $1 \mu \mathrm{m}$ de espesor.

Células de hojas senescentes de plantas con expresión de CP-GFP (H4 y H5 de la Fig. 3.5), fueron incubadas con el marcador Lysotracker Red. A: clorofila, B: GFP, C: Lysotracker; D y F: clorofila (azul) y Lysotracker (amarillo); E y G: 90 GFP (azul) y Lysotracker (amarillo). Las flechas indican VAS. Flechas cerradas indican VAS conteniendo GFP, las flechas abiertas indican VAS con GFP y 
Fig. 3.9 Espectros de emisión de fluorescencia en las bandas correspondientes a GFP y clorofila en cloroplastos y VAS de plantas de tabaco con expresión de CPGFP.

\section{GFP}

\section{clorofila}
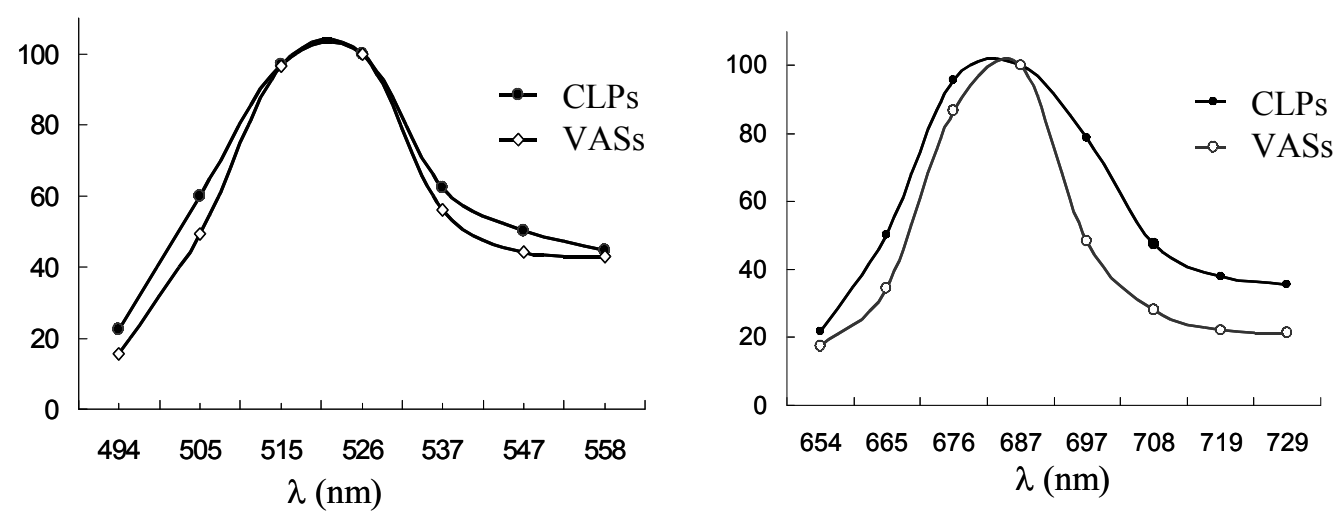

Espectros de emisión de fluorescencia de clorofila y GFP, en las VAS y en cloroplastos. Los valores son promedios de mediciones tomadas en al menos ocho cloroplastos y en ocho VAS. Las curvas están normalizadas al valor máximo de fluorescencia. Las condiciones de exitación fueron: 488nm para GFP, y $633 \mathrm{~nm}$ para clorofila 
3.3.2.3 El progreso acelerado de la senescencia foliar se relaciona con un aumento en el número de VAS

Factores ambientales y/o endógenos (v.g., hormonales, oscuridad, etc) aceleran el ritmo de la senescencia foliar (Drake et al., 1995; Capítulo 2 de esta Tesis). En este experimento se aceleró la senescencia de hojas de tabaco (H5 y H6 de la Fig. 3.5) escindidas de la plata sometiéndolas a: $\mathrm{A}=$ oscuridad, $\mathrm{y} \mathrm{B}=$ aplicación del regulador etefón, una fuente de etileno. Hojas tratadas con 100 ppm de etefón y hojas sin tratar se colocaron en oscuridad durante 2-3 días. En estas condiciones las hojas en oscuridad perdieron el $10 \%$ de la clorofila, mientras que en las hojas incubadas en oscuridad y tratadas con etefón la caída de la clorofila fue del $36 \%$, respecto del valor registrado al comienzo del tratamiento. Estas diferencias en el ritmo de la senescencia en oscuridad (A), y oscuridad más etefón (B), se reflejaron en un marcado aumento del número de VAS en el tratamiento B (Fig. 3.10). El tamaño y la composición de la población de VAS varío significativamente entre células de hojas tratadas y sin tratar con etefón (Tabla 3.1). El incremento del ritmo de senescencia provocada por etefón no afectó la cantidad de cloroplastos por célula, aunque el número de VAS prácticamente se duplicó (se registró un promedio de 1,48 y 0,68 VAS por cloroplasto en plantas tratadas con etefón y sin tratar, respectivamente, $p>$ 0,05). Alrededor del 44,5\% de las VAS del tratamiento A (oscuridad) contenían GFP, el $21 \%$ clorofila, y en el $14 \%$ colocalizaron GFP y clorofila (los valores corresponden al promedio de los porcentajes individuales de 18 secciones ópticas tomadas en seis células). El tratamiento B (oscuridad más etefón) causó un aumento significativo del número de VAS sin afectar la proporción de VAS con GFP (el $49,5 \%$ de las VAS con GFP, un valor estadísticamente igual al 44,5\% registrado en muestras controles). Por el contrario, las VAS con clorofila prácticamente están ausentes durante la senescencia acelerada con etefón (el 0,24 \% de las VAS contenía clorofila, y no se detectaron VAS con clorofila y GFP en este tratamiento). 
Fig. 3.10. Durante el progreso acelerado de la senescencia se observa un incremento del número de VAS.

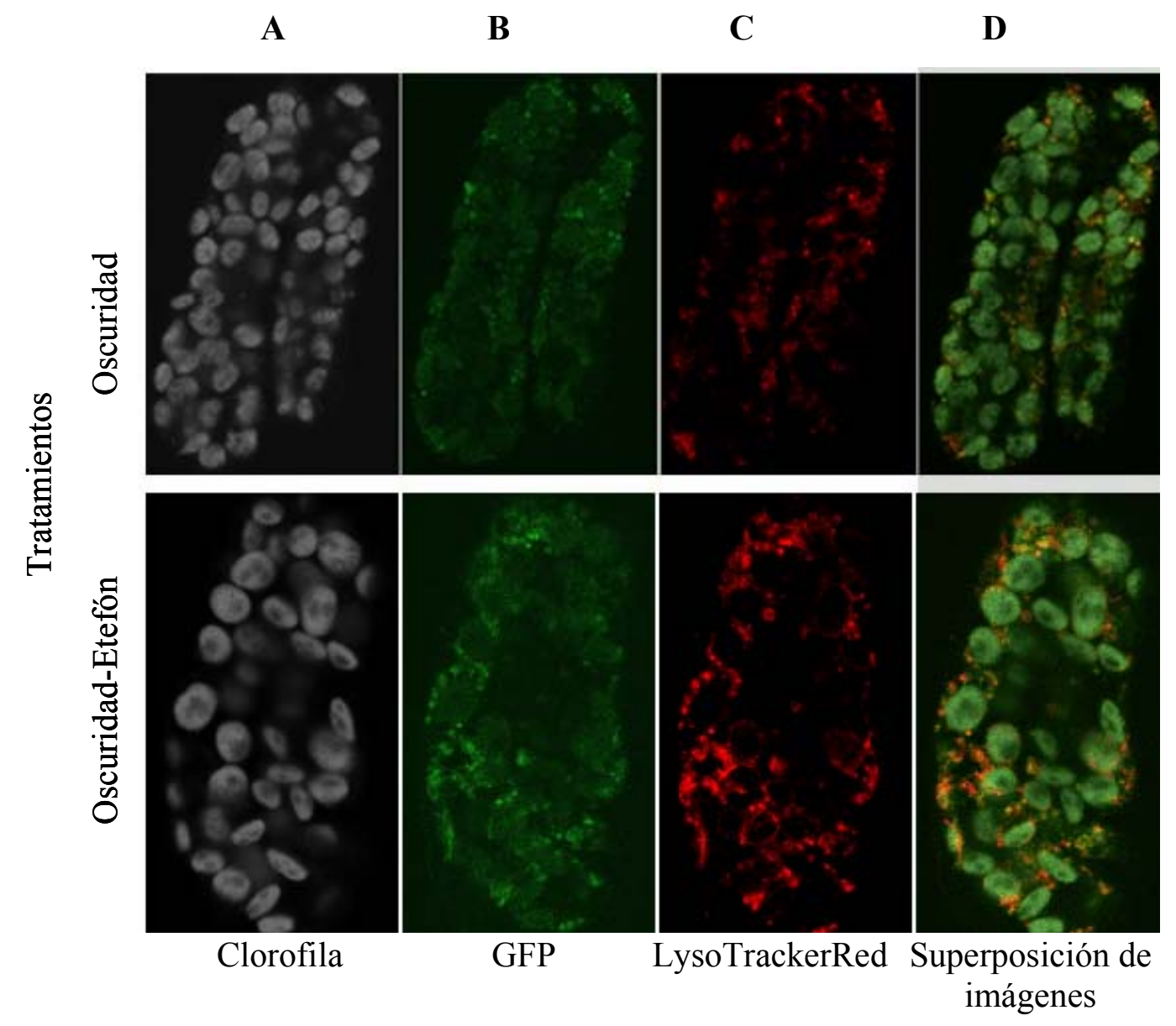

Células de hojas de tabaco de la línea CP-GFP incubadas en oscuridad, con o sin etefón, se incubaron con el marcador de compartimientos ácidos, LysoTracker Red. Paneles A: clorofila; B: GFP; C: LysoTracker Red; D: superposición de A, B, y C. En este panel se observa la colocalización de B y C (en color amarillo). 
Tabla 3.1. Cantidad y composición de VAS en hojas sometidas a tratamientos que alteraron el ritmo de la senescencia. Se representan los valores promedio por célula.

\begin{tabular}{|c|c|c|c|c|c|c|}
\hline Tratamiento & $\begin{array}{l}\text { Número de } \\
\text { cloroplastos/ } \\
\text { célula }\end{array}$ & $\begin{array}{l}\text { Número de } \\
\text { VAS/ } \\
\text { cloroplasto }\end{array}$ & $\begin{array}{l}\text { Número de } \\
\text { VAS/ célula }\end{array}$ & $\begin{array}{l}\text { Número de } \\
\text { VAS } \\
\text { con GFP * }\end{array}$ & $\begin{array}{l}\text { Número de } \\
\text { VAS con } \\
\text { clorofila* }\end{array}$ & $\begin{array}{c}\text { Número de VAS } \\
\text { con GFP } \\
\text { y clorofila* }\end{array}$ \\
\hline Sin etefón & 44,5 & 0,68 & 28 & 10,40 & 4,13 & 3,47 \\
\hline Con etefón & 40,5 & $1,48 * *$ & $61^{* *}$ & $28,06^{* *}$ & $0,88^{* *}$ & $0 * *$ \\
\hline
\end{tabular}

Se analizaron 6 células por cada tratamiento. Para cada célula se tomaron 3 secciones ópticas, de $1 \mu \mathrm{m}$ de espesor cada una. * Las VAS se identificaron por su señal con Lysotracker. $* *$ diferencias significativas entre tratamientos $(p>0,05)$

\subsection{DISCUSION}

\subsubsection{Una clase particular de vacuolas líticas se desarrolla durante la senescencia} foliar

La actividad de proteasas característica de las hojas senescentes se concentra en pequeños compartimientos, de alrededor de $1 \mu \mathrm{m}$ de diámetro, de lumen ácido y distribución citoplasmática. La detección de estos compartimientos con actividad proteolítica mediante marcadores específicos de vacuolas/lisosomas (Lysotracker y/o Rojo Neutro), sugiere que se trata de pequeñas vacuolas, cuya aparición se asocia a la senescencia (VAS). En estudios de inmunolocalización con muestras fijadas, realizados en experimentos que no son parte de esta Tesis, se detectó la presencia de una pirofosfasa vacuolar en las VAS, corroborando la naturaleza vacuolar de estas estructuras, mientras que la ausencia en las VAS de la acuaporina $\gamma$ TIP, presente en la vacuola central (VC), indica que las VAS y la VC son compartimientos independientes (Oteguí et al., 2005). La señal de actividad proteolítica in vivo sugiere 
que la actividad de proteasas cisteínicas asociada a la senescencia se concentra en las vacuolas asociadas a la senescencia (VAS), y no en la vacuola central, como han sugerido otros trabajos (Kinoshita et al., 1999; Srivalli et al., 2001; Hatsugai et al., 2004; Capítulo 2 de este Tesis). Esta discrepancia podría deberse a factores de diversa índole:

a) Diferencias en la velocidad de incorporación del sustrato de proteasas, o diferencias en la relación superficie/ volumen entre las VAS y la VC podrían favorecer la acumulación más rápida del sustrato de proteasas en las VAS. Sin embargo, no se han registrado cambios relativos entre la señal de proteólisis de las VAS y de la VC luego de incubaciones más prolongadas con los sustratos de proteasas, que pudieran permitir la acumulación de señal en la VC (datos no mostrados).

b) La observación in vivo permitiría discriminar dos tipos de vacuolas hasta ahora co-purificadas en fraccionamientos de vacuolas $\mathrm{y} / \mathrm{u}$ otros experimentos bioquímicos. Por ejemplo, la proteasa cisteínica aleuraína de células del mesófilo ha sido purificada en fraccionamientos de vacuolas centrales (Horwelda et al., 1992; Carter et al., 2004), aunque estudios de microscopía confocal han detectado esta proteasa en otros compartimientos, como el ER y pequeñas vacuolas líticas, además de la VC (Di Sansebastiano et al., 2001; Flückiger et al., 2003).

c) La actividad proteolítica in vivo sería mayor en las VAS que en la VC. Esto plantea dos situaciones. Por un lado, si bien la VC almacena gran cantidad de proteasas (Carter et al., 2004), diferencias en el medio, (i.e., el pH, presencia de cofactores) podrían favorecer una mayor actividad proteolítica en las VAS. Determinaciones del pH lumenal de la VC y las VAS muestran que el pH en las VAS es alrededor de 0,8 unidades menor que en la VC (Otegui et al., 2005). Por otra parte, las VAS podrían contener proteasas distintas a las detectadas en la VC. Entre las proteasas confinadas en las VAS se encuentra la proteasa cisteínica específica de la senescencia SAG12, que no fue detectada en la VC. La detección de VAS con actividad de proteasas cisteínicas en plantas sag12-2, mutantes para SAG12, indica que otras proteasas cisteínicas están contenidas en las VAS (resultado no mostrado). Experimentos de localización in vivo o inmunolocalización de otras proteasas asociadas a la senescencia serían útiles para esclarecer este punto.

Las presencia de VAS ha sido documentada durante la senescencia foliar de Arabidopsis y tabaco (y también en soja, aunque su análisis no es presentado en esta 
Tesis). Al menos en tabaco, la actividad de proteasas de tipo serínicas se concentra en pequeñas vacuolas líticas, indistinguibles en apariencia de las VAS detectadas con actividad de proteasas cisteínicas. Dado que la misma configuración de emisión/excitación de los sustratos de proteasas (R6502 y R6505) y GFP impide que estos fluorocromos sean utilizados simultáneamente, cabría la posibilidad que las VAS no sean una población homogénea de pequeñas vacuolas con una única batería de distintas proteasas en su interior, sino una población de distintas vacuolas según sus proteasas o proteasa predominante. Sin embargo, el hecho de que invariablemente la gran mayoría de las VAS marcadas por Lysotracker Red o Rojo Neutro contengan actividad de proteasas cisteínicas o serínicas es un argumento a favor de la existencia de una única población de VAS con distintos tipos de proteasas.

La detección de VAS durante la senescencia y su aparición limitada a células fotosintéticas sugirieron su participación en el proceso de degradación masiva de proteínas cloroplásticas.

\subsubsection{Las vacuolas asociadas a la senescencia foliar participan en la degradación de proteínas y otros componentes del cloroplasto}

En plantas de tabaco con expresión de CP-GFP una gran proporción de VAS contiene GFP. Además, una fracción de VAS contiene clorofila o algún catabolito de este pigmento, y en menor cantidad se observan VAS con GFP y clorofila. La disminución del nivel estable de CP-GFP durante la senescencia sugiere que GFP es degradada como otras proteínas del cloroplasto (Fig. 3.5), y la detección de VAS con clorofila en plantas salvajes de tabaco y de Arabidopsis (resultados no mostrados) reafirma que la aparición de componentes cloroplásticos en las VAS es un fenómeno natural, y no un posible artefacto asociado a la presencia de una proteína foránea en el cloroplasto. La estabilidad de la proteína GFP en las VAS y la intensa actividad de proteasas en estas vacuolas parecen hechos contradictorios. Si bien GFP es sensible a la degradación proteolítica en la vacuola central (Tamura et al., 2003), ha sido utilizada exitosamente como marcador de otros compartimientos líticos (Di SanSebastiano et al., 2001), y podría ser resistente al ataque por parte de las proteasas contenidas en las VAS. La señal de clorofila detectada sólo en las VAS cercanas a cloroplastos sugiere que este pigmento es inestable en las VAS. Las VAS podrían ser 
una vía de exportación y/o degradación de la clorofila. Se han evidenciado distintos mecanismos de degradación de clorofila (Amir-Shapira, et al., 1987; Takamiya et al., 2000), y en el contexto de esta Tesis es interesante que la actividad de la clorofilasa extra-cloroplástica ATHCOR1 aumenta durante la senescencia de pétalos de Arabidopsis (Benedetti y Arruda, 2002).

La señal de GFP y de clorofila en las VAS confirma la existencia de mecanismo/s de degradación extraplastidial de proteínas y otros componentes del cloroplasto, y demuestra la participación de las VAS en este proceso. La aparición y el aumento del número de VAS asociado al progreso de la senescencia foliar, y el marcado incremento de VAS en respuesta a la inducción acelerada de la senescencia provocada por la combinación de oscuridad y la aplicación de etefón, reflejan una correlación entre la degradación de componentes del cloroplasto y la presencia y abundancia de VAS. Con la información obtenida hasta el presente es difícil precisar la función exacta y el origen de las VAS. Las vacuolas vegetales pueden formarse a través de distintas vías: por mecanismos autofágicos, a partir de la fragmentación de vacuolas preexistentes, o a partir del RE (Marty, 1999). La presencia de actividad proteolítica y la ausencia de doble membrana en las VAS (Oteguí et al., 2005), sugieren que las VAS no representan autofagosomas (Thompson y Vierstra, 2005).

Las diferencias de composición entre las VAS y la VC sugiere que las VAS no se originarían por fragmentación de la vacuola central. Si las VAS son una población homogénea, es llamativa la presencia en su interior de componentes provenientes de la vía secretoria, como sag12, y del cloroplasto (proteínas y clorofila). En células de Chlamydomonas se han detectado estructuras de tipo vacuolar que contienen proteínas del cloroplasto (la subunidad $\alpha$ de la ATPasa cloroplástica, LHCII, y Rubisco), y proteínas provenientes de RE, como fosfatasa ácida (Park et al., 1999). En función de evidencias bioquímicas y de microscopía electrónica, los autores proponen un proceso de transferencia de proteínas desde el cloroplasto hacia las vacuolas. Asumiendo que las VAS son compartimientos de origen híbrido se plantean distintos posibles mecanismos de formación/función. Por ejemplo, las VAS podrían ser componentes del sistema de secreción, similares a los ricinosomas, o las vesículas $K V$ (Schmid et al., 2001; Toyooka et al., 2001) pero que interaccionan con el cloroplasto cargando proteínas y otros componentes plastidiales, para su degradación y/o transporte hacia otro/s compartimientos, v.g., VC. Por otra parte, las VAS podrían transportar proteasas, desde el RE u otra parte del sistema de 
secreción, hacia el cloroplasto. La descarga del contenido de las VASs podría desencadenar el desmantelamiento del cloroplasto, y la consiguiente formación de vesículas de origen plastidial conteniendo catabolitos de componentes cloroplásticos. Se han registrado cambios en la organización de distintas membranas cloroplásticas, como la vesiculización de la membrana interna del cloroplasto, asociada a la exportación de proteínas cloroplásticas en Chlamydomonas (Park et al., 1999), y a la transición de cloroplastos a cromoplastos en las frutos de pimiento (Capsicum annuum) (Hugueney et al., 1995). Las VAS podrían ser parte de un proceso de degradación masiva de componentes cloroplásticos sumamente regulado, y que implica la participación de compartimientos celulares especiales y la modificación del cloroplasto durante su desmantelamiento, sin afectar la integridad de la estructura remanente de la organela. 


\section{CAPITULO 4}

Identificación y análisis funcional de una proteasa con actividad asociada a la senescencia foliar de Arabidopsis thaliana 


\section{RESUMEN}

Se combinaron determinaciones de actividad proteolítica en gel (zimogramas) y técnicas de proteómica (geles bidimensionales, 2D, seguidos de espectrometría de masas) para detectar actividad proteolítica asociada a la senescencia foliar de Arabidopsis e identificar la/s proteasa/s responsable/s de la actividad. Se detectaron dos bandas de actividad proteolítica presentes en hojas jóvenes y que aumentan notoriamente en hojas senescentes. Ambas bandas fueron identificadas como productos del gen At3g14067, que codifica una proteasa serínica tipo subtilisina, sugiriendo que se trata de dos isoformas de esta enzima. Al menos en su forma activa, la proteasa subtilisina identificada se concentra en el espacio extracelular de hojas senescentes. Para establecer la función de At3g14067 se analizaron plantas mutantes (“knock out”) donde la expresión de este gen se encuentra inactivada por inserción de un fragmento de T-DNA. Las plantas mutantes presentan una ligera demora en el progreso de la senescencia foliar, más marcada en las hojas caulinares que en las hojas de la roseta. El efecto más notorio de la mutación de At3g14067 no se observa en el transcurso de la senescencia foliar de cada hoja, sino que se hace evidente durante el progreso del desarrollo reproductivo. La inactivación de la proteasa subtilisina se asocia con la producción de estructuras reproductivas más ramificadas que en el genotipo salvaje. El estudio realizado hasta el presente indica que At3g14067 no estaría implicado, al menos en forma directa, en el proceso de degradación masiva de proteínas asociado a la senescencia foliar. La ubicación subcelular de la actividad de la proteasa At3g14067 y su importancia en el desarrollo ontogénico a nivel de planta entera, junto a la información sobre la función de otras proteasas subtilisinas vegetales, sugieren que At3g14067 participaría en la regulación de la etapa reproductiva del desarrollo y la senescencia de la planta de Arabidopsis. 


\subsection{INTRODUCCION}

Los estudios de expresión génica a gran escala desarrollados recientemente han permitido vislumbrar la cantidad de genes comprometidos y la complejidad de las redes moleculares que operan durante la senescencia (He et al., 2001; Guo et al., 2004; Buchanan Wollaston et al., 2005). Se han identificado al menos 2500 genes asociados a la senescencia (SAG) de Arabidopsis (Gepstein 2004), sin embargo, se desconoce la relevancia de cada uno de estos SAG en la iniciación y/o ejecución del proceso, y sólo se infiere a partir de sus secuencias la función del 50-70\% de los genes identificados (Gepstein et al., 2003; Buchanan Wollaston et al., 2005). El conocimiento sobre la función particular cada gen y la elucidación de rutas metabólicas se ha llevado a cabo en gran medida con el empleo de plantas mutantes, producidas a gran escala por mutagénesis química o inserción de T-DNA y la posterior selección y análisis de los fenotipos de interés (Bouché y Bouchez, 2001; Radhamony et al., 2005). En su revisión sobre aspectos moleculares de la senescencia foliar, Lim et al. (2003) resaltan la importancia y potenciales alternativas que proporciona el uso de plantas mutantes como herramienta en el estudio funcional de genes y de las vías metabólicas involucradas en la senescencia.

Se conocen algunos mutantes de Arabidopsis con alteraciones en la senescencia foliar, en su mayoría caracterizados a nivel fisiológico y/o molecular, a través de mediciones de los cambios en el contenido de proteínas y clorofila, eficiencia fotoquímica $\left(\mathrm{Fv}^{\prime} / \mathrm{Fm}^{\prime}\right)$, longevidad foliar, y/o la expresión de SAG y PAG (genes asociados a funciones fotosintéticas). Los genes afectados en estas mutaciones poseen variadas funciones, y participan en diversos procesos: por ejemplo, mutaciones que afectan la percepción y respuestas al etileno aceleran (Jing et al., 2002; Jing et al., 2005) o demoran (Grbic y Bleckeer, 1995) la senescencia foliar. etr1 presenta una alteración en el gen que codifica al receptor de etileno, ETR1 (Bleecker et al., 1988), y las plantas mutantes para este gen muestran senescencia foliar demorada y mayor longevidad foliar que el genotipo salvaje (Grbic y Bleckeer, 1995). ORE4-1 codifica una proteína ribosomal plastídica y su inactivación prolonga la longevidad foliar (Woo et al. 2002). Los mutantes apg8 y apg7, poseen distintos defectos en la vía autofágica de degradación de proteínas citoplasmáticas y se 
caracterizan por una gran sensibilidad a la deficiencia de nutrientes y senescencia prematura en tales condiciones (Hanaoka et al., 2002; Doelling et al., 2002). Entre otros mutantes relacionados con la degradación de proteínas se caracterizaron ore 9 y dls. ore 9 posee longevidad extendida y senescencia foliar demorada. Este mutante fue identificado en "screenings" realizados durante la senescencia natural y en hojas escindidas de la planta y sometidas a oscuridad (Oh et al., 1997). Posteriormente, por mapeo genético y clonado posicional se identificó ORE9 como una proteína de tipo F-Box, componente del complejo SCF que participa en la ubiquitinación de proteínas. ORE9 interactúa con SKP, otro componente del complejo SCF (Woo et al., 2001). El fenotipo dls (delayed leaf senescence) es producto del bloqueo del gen AtALE1, que codifica una arginil-tRNA arginiltransferasa, un componente de la vía de degradación "N- end rule", una ruta del sistema de ubiquitinación eucariota poco conocida en plantas (Yoshida et al., 2002). Por la ubicación citosólica y/o nuclear de AtALE1, los autores sugieren su participación en la degradación de represores de la senescencia, como plantean Woo et al. (2001) respecto de ORE9. Si bien algunos componentes de la vía de degradación del proteasoma han sido identificados como genes asociados a la senescencia (SAG), ni ORE9, ni AtALE1 fueron detectados en los estudios de expresión génica asociada a la senescencia realizados hasta el presente.

En una aproximación alternativa, se han examinado los fenotipos producto de la inactivación de genes que codifican determinadas proteasas cloroplásticas. La inactivación de la proteasa $\mathrm{ClpC} 1$ produce retardo del crecimiento, clorosis y menor actividad fotosintética (Sjögren et al., 2004). Mutaciones en las metaloproteasas FtsH han dado lugar a fenotipos variegados, y fenotipos indistinguibles del genotipo salvaje (Żelisko et al., 2005). Las líneas "antisentido" de tabaco para la proteasa aspártica CND41 presentan, en condiciones de déficit de nitrógeno, un retraso en el desarrollo y por lo tanto en el inicio de la senescencia (Kato et al., 2004). En general, los mutantes de proteasas cloroplásticas examinados presentan distintas anomalías que no parecen incidir en el progreso de la senescencia. El conocimiento sobre la identidad y función particular de proteasas asociadas a la senescencia es superficial si se lo compara con la información acerca de las funciones específicas de proteasas involucradas en otros procesos, como la maduración y/o removilización de proteínas en semillas (Okamoto et al., 2003; Nakaune et al., 2005), y en algunos casos de muerte celular programada (Elbaz et al., 2002; Hatsugai et al., 2004). Teniendo en cuenta que más de 30 SAGs codifican proteasas (Guo et al., 2004), los estudios de 
tipo funcional sobre los productos génicos correspondientes son menos que escasos. Uno de los pocos trabajos es el realizado por Rojo et al. (2003), sobre la actividad de la proteasa de procesamiento vacuolar $\gamma \mathrm{VPE}$ durante la senescencia foliar. $\gamma \mathrm{VPE}$ estaría involucrada en la maduración de una invertasa y una carboxipeptidasa vacuolares, aunque la relevancia de la proteasa en el progreso de la senescencia no ha sido completamente esclarecida. El fenotipo producto de la inactivación de la proteasa específica de la senescencia SAG12 (Lohman et al., 1994) no presenta diferencias notorias respecto del fenotipo salvaje (Capítulo 3 de esta tesis). Por otra parte, mientras que SAG12 muestra alta expresión a nivel de ARNm (Lohman et al., 1994), está ausente en análisis de proteómica funcional de proteasas cisteínicas asociadas a la senescencia (van der Hoorn, et al., 2004). Esto podría deberse a cuestiones metodológicas, o a que la proteasa es poco abundante a pesar de su marcada expresión a nivel de ARNm. Hay ejemplos similares referidos a otras proteasas. Los niveles de ARNm de la proteasa subtilisina ARA12 son abundantes en tallos y hojas, mientras que a nivel de proteína ARA12 es detectada en tallos y silícuas, pero prácticamente no aparece en hojas (Hamilton et al., 2003). Dado que la cantidad de un determinado tránscrito no siempre se refleja en la cantidad de su proteína correspondiente (Gygi et al., 1999), sería útil contar con estudios detallados sobre el proteoma asociado a la senescencia, como un punto de partida para la identificación de proteasas asociadas a la senescencia y su posterior análisis funcional. Los proteomas asociados a la senescencia foliar realizados hasta el momento provienen de extractos foliares totales y/o cloroplastos enteros, y no han sido útiles para establecer la aparición o los cambios en proteínas minoritarias, como es el caso de la mayor parte de las proteasas (Wilson et al., 2002; Schiltz et al., 2004). Para identificar proteasas asociadas a la senescencia sería útil contar con proteomas más acotados, de fracciones subcelulares o bien de tipo funcional de proteínas. Los proteomas de membranas tilacoidales, lumen del cloroplasto, vacuolas, apoplasto, sólo han sido estudiados a partir de material no senescente (Whitelegge, 2003; Schubert et al., 2002; Carter et al., 2004; Boudart et al., 2005). El fraccionamiento de proteínas de acuerdo a sus características funcionales dio lugar por ejemplo, al proteoma de fosfoproteínas de la membrana plasmática (Nühse, et al., 2004). En el caso de proteasas, se han analizado proteomas por medio de marcación química (Capítulo 2 de esta tesis, Greenbaum et al., 2000; van der Hoorn et al., 2004; Kokcs et al., 2003). Por otra parte, las proteasas con actividad asociada a la senescencia foliar 
se han detectado y caracterizado exitosamente a través de ensayos de actividad in vitro en gel (zimogramas, Capitulo 2 de esta tesis, Morris et al., 1996; Jiang et al., 1999; Wagstaff et al., 2002) aunque en pocos casos se ha identificado el gen correspondiente a la/s proteasa/s detectada/s (Funk et al., 2002).

El objetivo de este trabajo fue identificar proteasas cuya actividad aumenta durante la senescencia y establecer su función. Los pasos de este estudio abarcaron a) la detección de la proteasa activa, b) la identificación de su gen correspondiente, y c) la caracterización de plantas mutantes knock out para el gen identificado.

\subsection{MATERIALES Y METODOS}

\subsubsection{Detección e identificación de proteasas con actividad asociada a la senescencia de Arabidopsis.}

Realicé esta parte del trabajo en el Laboratorio de Fisiología y Biología Molecular de Plantas, Universidad de Turku, Finlandia (Convenio de Cooperación Academia de Finlandia - SECTIP, 2003-2005).

\subsubsection{Material vegetal, condiciones de cultivo y muestreos}

Se utilizaron plantas de Arabidopsis thaliana ecotipo Columbia. Las semillas se sembraron en macetas con tierra estéril. Después de dos días en oscuridad a $4^{\circ} \mathrm{C}$, las macetas fueron trasladadas a cámaras de crecimiento a $24^{\circ} \mathrm{C}$, a un PPFD de 100 $\mu$ moles $\mathrm{m}^{-2} \mathrm{~s}^{-1} \mathrm{y}$ un fotoperíodo de $16 \mathrm{~h}$.

El análisis de la actividad proteolítica durante el progreso de la senescencia fue realizado con hojas jóvenes y maduras de plantas en estado vegetativo (antes de la emergencia del escapo floral, o "bolting"), y hojas senescentes de plantas en estado vegetativo y reproductivo (antes y después de "bolting"). En función del grado de expansión foliar, y del contenido de clorofila y de proteínas foliares solubles, se consideraron los estadíos: J, hojas jóvenes, en crecimiento, M: hojas a máxima expansión, con los niveles máximos de clorofila y proteínas, denominadas también 
como "no senescentes", NS) y S: hojas senescentes, $\mathrm{S}_{1}$ : con el 50-60 \% de la clorofila y alrededor del $70 \%$ de proteínas, respecto de $\mathrm{M}, \mathrm{y} \mathrm{S}_{2}$; un estadío más avanzado de la senescencia, con menos del $40 \%$ de la clorofila y proteínas respecto de M. El contenido de clorofila se midió por espectrofotometría como en Iskeep y Bloom (1985). Las proteínas totales se cuantificaron por el método de Bradford (1976), y se analizaron en geles SDS-PAGE teñidos con Coomassie Blue. Se comparó la cantidad de clorofila, proteínas y de actividad proteolítica de los distintos estados de desarrollo tomando el área foliar como referencia.

\subsubsection{Detección y purificación de proteasas con actividad asociada a la senescencia}

1- Detección de proteasas

Se comparó la actividad in vitro de proteasas de extractos totales de hojas de distintos estadíos de desarrollo ( $\mathrm{J}, \mathrm{M}, \mathrm{S}_{1} \mathrm{y} \mathrm{S}_{2}$ ) en zimogramas SDS-PAGE, de la forma descripta en el Capítulo 2 de esta tesis.

2- Purificación de las proteasas de interés

Una vez detectadas las proteasas de interés (con actividad asociada a la senescencia), se prepararon extractos totales de hojas senescentes $\left(S_{1}\right.$ y $\left.S_{2}\right)$ para su separación en geles bidimensionales (2D: isoelectroenfoque, IEF, seguido de SDSPAGE). Los ensayos de actividad proteolítica imposibilitan el uso de las técnicas y buffers de desnaturalización irreversible de proteínas empleados normalmente en la separación de proteínas en geles 2D (Méchin et al., 2003), por lo que se ensayaron distintas metodologías de preparación y separación de la muestra. Finalmente, se estableció el siguiente procedimiento:

2a- Preparación y solubilización de la muestra

Extractos de alrededor de $500 \mathrm{mg}$ de hojas senescentes se concentraron y desalaron por centrifugación en filtros Microcon ${ }^{\circledR}$ (Millipore), de tamaño de poro de $10 \mathrm{kDa}$, se resuspendieron en $250 \mu \mathrm{l}$ de agua bidestilada, Triton X-100 2\%, DTT 15 $\mathrm{mM}$, urea $2 \mathrm{M}$, leupeptina $20 \mu \mathrm{M}$, y anfolitos $\mathrm{pH}$ 4-7 (BioRad) 0,2\%, y se 
centrifugaron a $90000 \mathrm{~g}$ durante $20 \mathrm{~min}$. El sobrenadante resultante se analizó en geles 2D.

2b- Separación de muestras en geles 2D

Isoelectroenfoque: Se utilizaron geles con un gradiente lineal de $\mathrm{pH}$ inmovilizado (IPG) en rangos de separación de pH 3-10 y pH 4-7 (BioRad). El isoelectroenfoque se realizó a $50 \mathrm{~V}$ durante 4 h, $100 \mathrm{~V} \mathrm{1h,200} \mathrm{V} \mathrm{1h,} \mathrm{y} \mathrm{se} \mathrm{continuó} \mathrm{a}$ $10000 \mathrm{~V}$ con un incremento lineal de voltaje hasta llegar a un total de $60000 \mathrm{Vh}$. Se realizaron al menos dos repeticiones (dos tiras IPG) en cada isoelectroenfoque. Una vez finalizado el isoelectroenfoque las tiras se guardaron a $-80^{\circ} \mathrm{C}$, o se equilibraron en buffer 1X de solubilización (Laemmli, 1970) para su inmediata separación en la segunda dimensión.

Segunda dimensión: Se utilizaron geles SDS-PAGE de 12\% de archilamida, con y sin gelatina, preparados como en el Capítulo 2 de esta tesis. Muestras (tiras de IPG) separadas en un mismo isoelectroenfoque se corrieron simultáneamente en geles SDS-PAGE con y sin gelatina.

2c- Revelado de proteínas y actividad proteolítica

Terminada la electroforesis, los geles con gelatina se trataron para la detección de actividad proteolítica (Capitulo 2 de esta Tesis), y los geles sin gelatina se tiñeron con plata como en Shevchenko et al. (1996).

2d- Purificación de las proteasas

Cada zimograma y el correspondiente gel teñido con plata se superpusieron y los "puntos" de proteína correspondientes a "puntos" de actividad se cortaron del gel con un escalpelo y se guardaron a $-20^{\circ} \mathrm{C}$ para su posterior análisis.

\subsubsection{Identificación por espectrometría de masas}

Los "spots" de proteína se sometieron a digestión con tripsina (Trypsin Gold, Promega) como en Shevchenko et al. (1996). Los péptidos se eluyeron de los trozos de gel por lavados alternados con 5\% de ácido fórmico y $80 \%$ de acetonitrilo, y se concentraron y desalaron en microcolumnas POROS R3 (Perseptive Biosystems, Framingham, MA) como en Battchikova et al. (2005). Las muestras se analizaron por MALDI-TOF (Voyager-DE PRO Mass Spectrometer, Applied Biosystems, Foster 
City, CA), y por cromatografía líquida y espectrometría de masas en tamdem -ESI MS/MS (API QSTAR, Applied Biosystems, Nano Electrospray Protana, Toronto, Canada, conectado a nano HPLC), como en Battchikova et al. (2005). Los péptidos de autodigestión de tripsina se utilizaron para la calibración del espectro en el análisis por MALDI, y se excluyeron en la adquisición del espectro por ESI MS/MS.

\subsubsection{Analisis bioinformático}

La identificación de proteínas se realizó a través del programa Mascot (www.matrixscience.com), en la base de datos del National Center for Biotechnology Information (NCBI) (www.ncbi.nlm.nih.gov). En esta búsqueda se permitieron errores de masas menores a 100 ppm, y la omisión de un corte por tripsina.

Los programas TargetP y ClustalW de Expasy (http://ca.expasy.org), y el programa iPSORT (http://hc.ims.u-tokyo.ac.jp/iPSORT/) se utilizaron para analizar distintas características de la proteasa identificada, como la homología con otras proteasas, potenciales sitios de glicosilación y predicciones de localización subcelular.

\subsubsection{Localización subcelular de la actividad de la proteasa identificada}

Extracción de fluído extracelular (FEC)

Se realizó como en Boudart et al. (2005). Las hojas fueron cortadas, sin pecíolos, sumergidas en manitol 0,4 M y sometidas a vacío durante $3 \mathrm{~min}$. Luego se secaron suavemente con papel de filtro y se centrifugaron a $200 \mathrm{rpm}$ durante $20 \mathrm{~min}$. El FEC fue colectado del fondo del tubo. El FEC y el tejido foliar post extracción de fluído fueron guardados a $-80^{\circ} \mathrm{C}$ hasta el desarrollo de los zimogramas.

4.2.2 Análisis funcional de la proteasa asociada a la senescencia a través del uso de plantas mutantes para el gen identificado.

\subsubsection{Selección de líneas mutantes y condiciones de cultivo}

Se utilizaron plantas de Arabidopsis thaliana ecotipo Columbia salvajes, y mutantes "knock out" por inserción de T-DNA en el gen identificado. Las plantas 
mutantes pertenecen a la colección SALK, y fueron seleccionadas en la base de datos del Instituto de Análisis Genómicos SALK (www.arabidopsis.org, SIGNAL TDNAExpress). Los "stocks" de semillas que proporciona el Instituto SALK contienen semillas homo- y heterocigotas para el inserto de T-DNA, por lo que se realizó una selección de plantas mutantes homocigotas basada en la actividad proteolítica de at3g14067 (por medio de zimogramas). Se identificaron como plantas mutantes homocigotas a aquellas que carecen de actividad de at3g14067.

\section{Condiciones de cultivo}

Semillas de plantas mutantes y salvajes se trataron como en 4.2.1.1. En este caso las plantas crecieron con un fotoperíodo de $12 \mathrm{~h}$ durante 1 a 3 semanas desde la germinación, y luego a luz continua, bajo un PPFD de $150 \mu$ moles $\mathrm{m}^{-2} \mathrm{~s}^{-1}$, salvo excepciones especificadas en Resultados.

\subsubsection{Caracterización de la senescencia foliar de plantas mutantes.}

Se consideró a la variación del contenido de clorofila foliar a lo largo del tiempo como principal parámetro de senescencia.

Senescencia de hojas adheridas a la planta

A partir del momento de alargamiento del escapo floral ("bolting"), y a lo largo del tiempo, se registró el contenido de clorofila, y la supervivencia de hojas de la roseta y hojas caulinares. Para esto se eligieron la novena hoja de la roseta y la quinta hoja caulinar, contando desde la base, que se marcaron para su seguimiento temporal. A los 30 días después de "bolting" se registró la actividad fotoquímica de las hojas de la roseta. Las mediciones de clorofila se realizaron de forma no destructiva, con el medidor portátil SPAD502 (Minolta, Japón). El rendimiento cuántico del fotosistema II se midió con el medidor de fluorescencia Fluorescence Monitoring System 2 (Hansatech Instruments Ltd, Norfolk, UK).

Senescencia de hojas cortadas y colocadas en oscuridad

Hojas de plantas en estado vegetativo, de la posición quinta de la roseta contando desde el ápice, fueron cortadas y colocadas en cápsulas de Petri con papel 
de filtro humedecido. El valor de clorofila de cada hoja se registró con el medidor SPAD 502, bajo luz verde no actínica, cada dos días hasta la caída total de clorofila.

4.2.2.3 Caracterización del desarrollo reproductivo de plantas mutantes. Análisis del patrón de ramificaciones reproductivas.

1- Registro del número total de ramificaciones producidas al final del desarrollo Se realizó la disección y conteo de las estructuras reproductivas producidas por la planta al final de su ciclo de vida, considerado como tal cuando toda la planta se encontró seca. Las ramificaciones producidas en cada inflorescencia se discriminaron de acuerdo al orden de ramificación correspondiente (Fig. 4.1).

2- Número de ramificaciones producidas a lo largo del tiempo

Se monitoreó en forma no destructiva el número de ramificaciones producidas por cada planta, desde una semana después de floración y a lo largo del tiempo hasta la muerte de la planta. Se realizaron tres muestreos semanales desde "bolting", y un cuarto muestreo seis semanas después. En este experimento se discriminó la inflorescencia principal del resto de las inflorescencias. Sobre la inflorescencia principal, también se registró el momento de aparición y número de hojas caulinares y ramificaciones, desde el elongamiento del eje y hasta que cesó su crecimiento.

Para cada experimento se realizaron cinco repeticiones independientes con grupos de entre 6 a 10 plantas cada uno.

Análisis estadístico

Los valores presentados corresponden a las medias muestrales y sus errores estándard. La comparación de medias se realizó con el test de Student ( $p>0,05$ y p> 0,01) o el test LSD ( $>0,05)$. 
Fig. 4.1. Morfología de Arabidopsis en la etapa reproductiva de desarrollo. Esquema de la planta utilizado como referencia en el análisis morfológico (modificado de Mündermann et al., 2005).

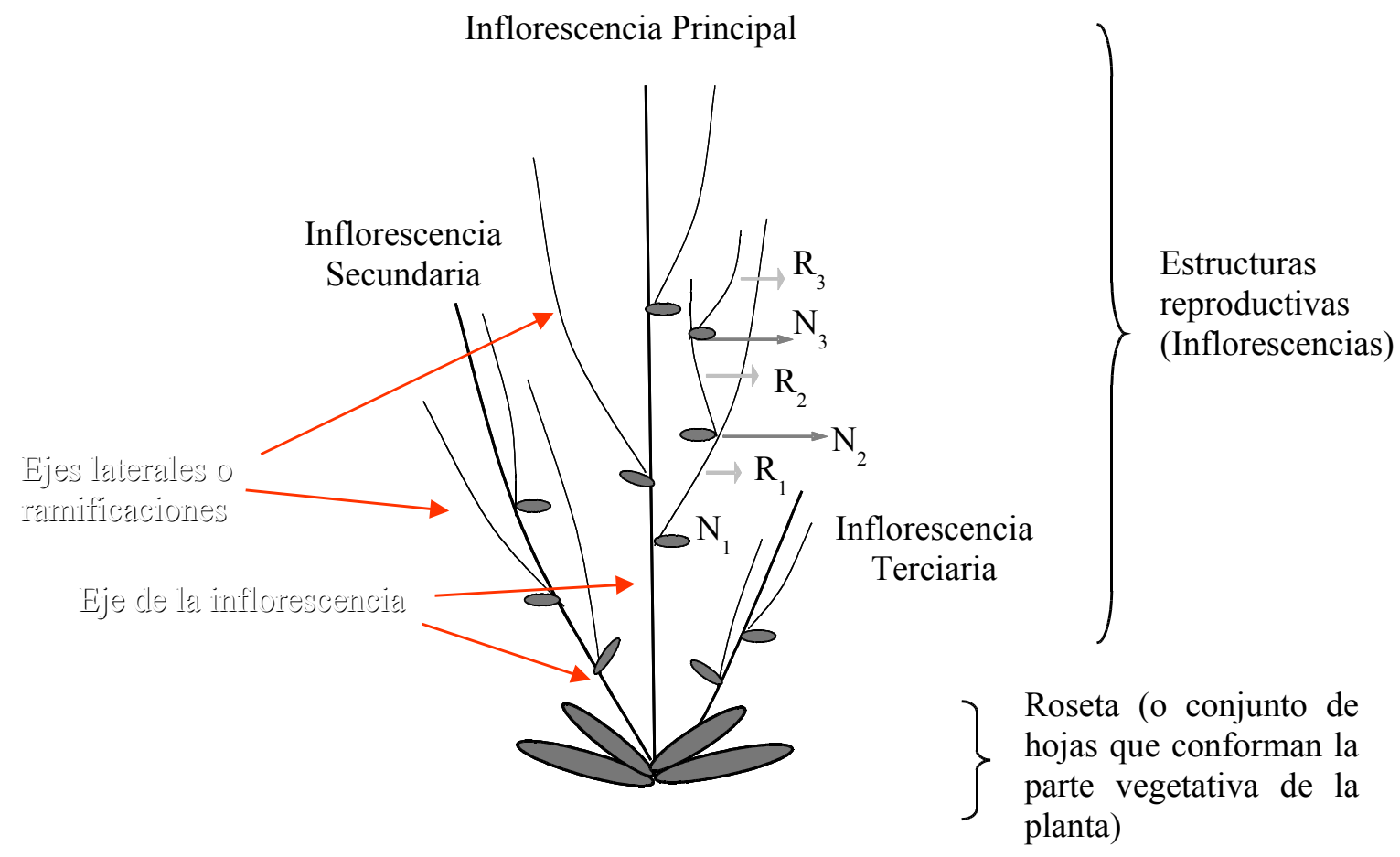

El patrón de desarrollo reproductivo es modular. Las inflorescencias originadas en el meristema axilar de hojas de la roseta (inflorescencia axilar secundaria, terciaria etc., según el orden de aparición) repiten el mismo patrón de desarrollo que la inflorescencia principal Cada inflorescencia se compone de un eje o raquis, de donde surgen ejes secundarios, llamados paracladios o ramificaciones. Los nodos $(\mathrm{N})$, donde se originan las brácteas $\mathrm{u}$ "hojas caulinares" y las ramificaciones, se denominaron $\mathrm{N}_{1}, \mathrm{~N}_{2}, \mathrm{~N}_{3}$, etc., según el orden de aparición en cada inflorescencia. Las ramificaciones $(\mathrm{R})$ siguen el mismo orden, $\mathrm{R}_{1}, \mathrm{R}_{2}, \mathrm{R}_{3}$, etc. Los frutos (sil lícuas) no se han considerado en el diagrama. 


\subsection{RESULTADOS}

\subsubsection{Detección e identificación de proteasas con actividad asociada a la senescencia de Arabidopsis.}

4.3.1.1. En experimentos con zimogramas, la actividad proteolítica asociada a la senescencia foliar se debe principalmente al incremento de actividad de dos bandas.

En la figura Fig. 4.2.a se muestran los cambios en el nivel de proteínas y proteasas activas a lo largo del desarrollo foliar de Arabidopsis. Los distintos estadíos de desarrollo (hojas jóvenes, maduras y en dos estados de senescencia) se definieron y caracterizaron en función del contenido de proteínas y clorofila (Fig. 4.2.b). En el zimograma (Fig.4.2.a) se puede observar actividad proteolítica exclusiva de determinados estadíos, aunque la mayor parte de las proteasas muestran cambios (aumento o disminución) en los niveles de actividad a lo largo del desarrollo foliar. Las numerosas bandas activas y el alto grado de actividad en el gel impiden una buena resolución y separación de las proteasas entre sí. Para examinar con mayor precisión la actividad proteolítica asociada a la senescencia se redujo la cantidad de muestra y el tiempo de incubación del zimograma (Fig 4.2.c). Con este ajuste metodológico se distinguieron dos bandas como las responsables de la mayor parte de la actividad proteolítica asociada a la senescencia (marcadas con un asterisco en las Fig. 4.2 a y c). El aumento de actividad de estas proteasas se observa durante la senescencia foliar en plantas en estado vegetativo y en post-floración (resultado no mostrado).

Una vez detectadas las proteasas con actividad asociada a la senescencia, las muestras de hojas senescentes se analizaron en geles bidimensionales (2D). La separación de proteínas en dos dimensiones se utilizó como método de purificación y obtención de proteasas para su posterior identificación por espectrometría de masas, y además permitió examinar la posibilidad de que hubiera más de una proteasa activa con un mismo peso molecular. Los zimogramas 2D y geles $2 \mathrm{D}$ realizados no permitieron superponer exactamente de todos los "puntos" de actividad con sus correspondientes "puntos" teñidos por plata. Esto se debió principalmente a dos 
causas: 1- el estado "semi desnaturalizado" de la muestra impidió el correcto enfocado de muchas proteínas, y 2- la cantidad de proteína representada por algunas proteasas activas en zimogramas se encontraba por debajo del límite de detección de la tinción por plata. A pesar de estas dificultades, las proteasas con actividad proteolítica asociada a la senescencia se enfocaron correctamente y se detectaron en el gel teñido con plata (Fig. 4.3).

Fig. 4.2 Actividad de proteasas asociadas a la senescencia foliar de Arabidopsis

A) Perfil de proteínas y de actividad de proteasas en hojas jóvenes (J), maduras (M), y en dos estados de senescencia, $\left(\mathrm{S}_{1}\right.$ y $\left.\mathrm{S}_{2}\right)$.

B) Valores de clorofila y proteínas de cada estadío de desarrollo, analizados en los geles de las Fig. A
Gel SDS-PAGE

$\underline{\text { Zimograma }}$
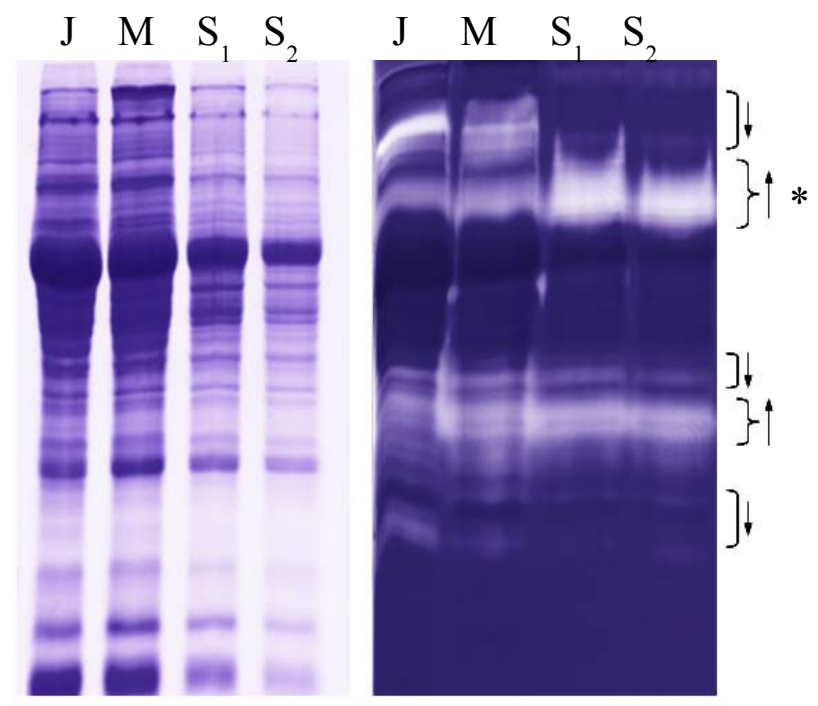

$\begin{array}{llll}\mathrm{J} & \mathrm{M} & \mathrm{S}_{1} & \mathrm{~S}_{2}\end{array}$ $\%$ de Proteínas $941007630 \%$ de Clorofila 781005030

El zimograma fue incubado a $\mathrm{pH}$ 4,7. Las flechas indican aumentos o disminución de actividad asociada a la senescencia. El asterisco señala la actividad proteolítica asociada a la senescencia más notoria del perfil. Las hojas analizadas provienen de plantas en estado vegetativo. 


C) Dos proteasas son
responsables de la mayor parte de
la actividad asociada a la
senescencia (marcadas con un
asterisco). NS= hojas no
senescentes. $\mathrm{S}_{1}$ y $\mathrm{S}_{2}=$ hojas
senescentes.

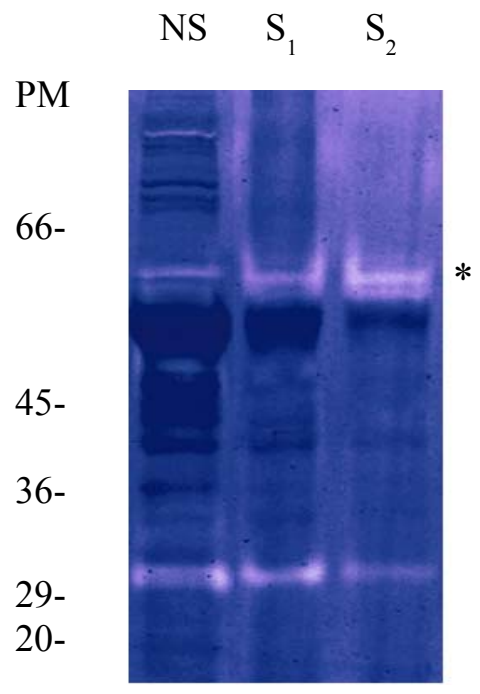

Fig. 4. 3 Las bandas de actividad asociada a la senescencia pueden resolverse en geles bidimensionales

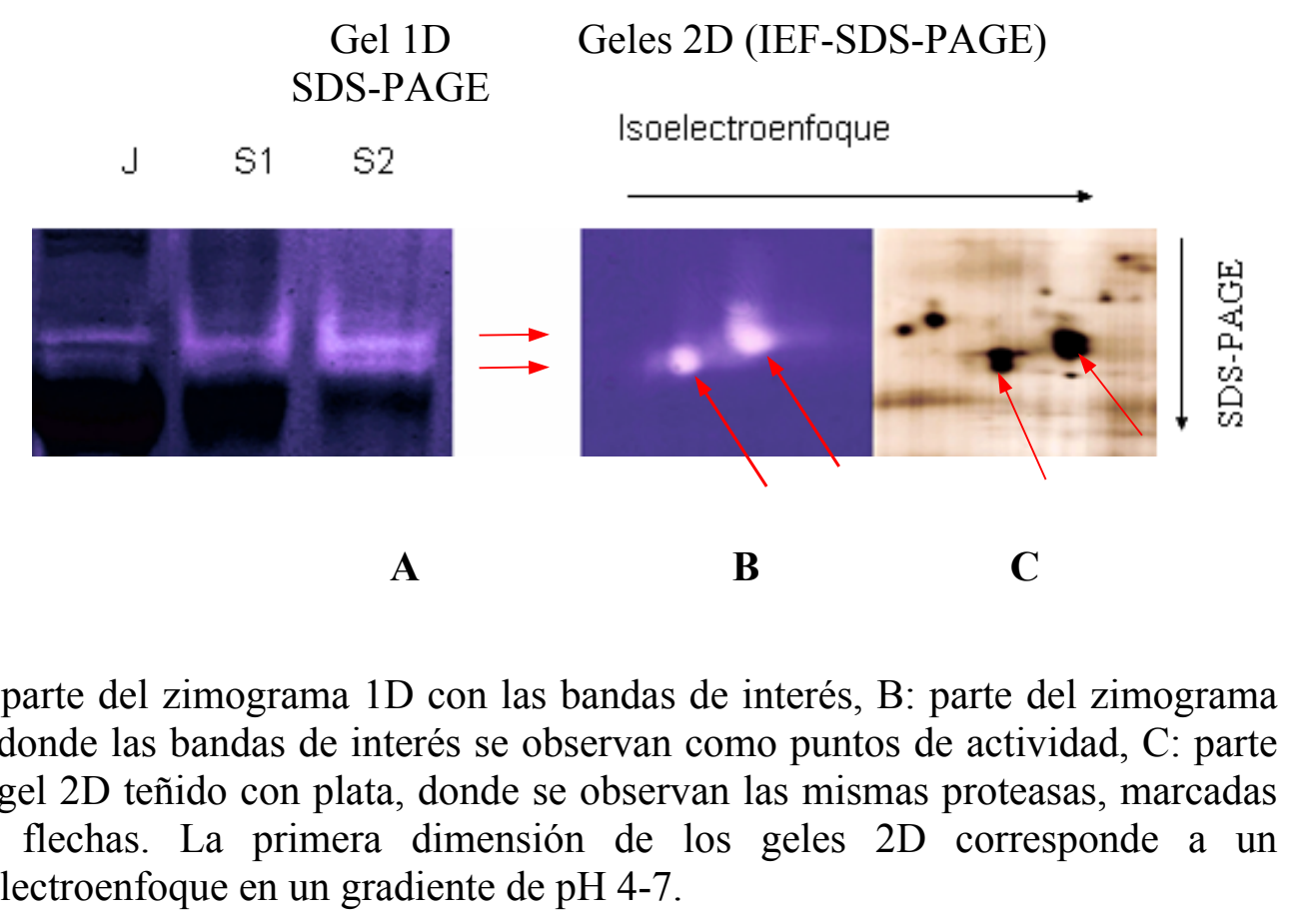


4.3.1.2. La actividad asociada a la senescencia detectada en zimogramas es producto de una proteasa serínica tipo subtilisina.

Las proteínas teñidas con plata correspondientes a las proteasas activas se sometieron a digestión enzimática por tripsina, y los péptidos resultantes se analizaron por MALDI-TOF, pero la poca señal de los espectros obtenidos por este método imposibilitó la correspondiente identificación. Se consideraron y modificaron distintos parámetros, desde la cantidad de muestra analizada hasta la forma de obtención de los péptidos (i.e., desnaturalización por tratamientos térmicos, digestión química). Luego de repetidos intentos fallidos de análisis por MALDI, se recurrió al análisis espectrométrico por ESI MS/MS. El uso de ESI MS/MS es más costoso y complejo que MALDI, pero los porcentajes de éxito en la identificación de proteínas por esta método suelen ser más altos (Larsen y Roepstorff, 2000). A través del análisis con ESI MS/MS se identificaron las proteasas con actividad asociada a la senescencia. Ambas proteasas son codificadas por el mismo gen, GI: 18400262 en la base de datos de NCBI, At3g14067 en la base de datos correspondiente al genoma de Arabidopsis. El gen At3g14067 codifica una proteasa serínica del tipo subtilisina. En la Fig. 4.4 se muestra el resultado del proceso de identificación de una de las bandas analizadas.

\subsubsection{Características de la proteasa subtilisina At3g14067}

At3g14067 posee una masa nominal de $82,4 \mathrm{kDa}$ y un punto isoeléctrico $(\mathrm{pI})$ nominal de 6,29. De acuerdo a los zimogramas realizados, At3g14067 tendría al menos dos isoformas activas, de alrededor de 59 y $61 \mathrm{kDa}$, y pIs de alrededor de $5 \mathrm{y}$ 5,5 respectivamente. La diferencia entre los valores nominales y empíricos probablemente se debe a que corresponden a la preproproteasa y a las proteasas maduras respectivamente. Diferencias de tamaño del mismo orden, alrededor de 20 $\mathrm{kDa}$, se observan luego de la maduración de algunas proteasas subtilisinas conocidas (Yamagata et al., 1994). At3g14067 presenta las mayores homologías de secuencia con la proteasa tipo subtilisina presunta Q6K765 de arroz (Oryza sativa), y con la proteasa subtilisina ARA12, de Arabidopsis. El análisis espectrométrico realizado en esta tesis se enfocó en la identificación de proteínas, y no abarcó el estudio de las 
distintas características que podrían distinguir entre sí a las posibles isoformas identificadas, i.e., glicosilación, fosforilación, o si las isoformas observadas son en realidad un producto de degradación parcial de la proteasa. Las diferencias de tamaño molecular y pI observadas podrían deberse a glicosilaciones (Packer y Keatinge, 2001). De acuerdo a las predicciones in silico, At3g14067 posee 4 sitios potenciales de glicosilación, y un péptido señal, características compartidas por muchas de las proteasas subtilisinas. La presencia de un péptido señal, de 30 aminoácidos, indica que esta subtilisina está dirigida a la vía secretoria.

Fig 4.4 Identificación de una de las bandas analizadas.

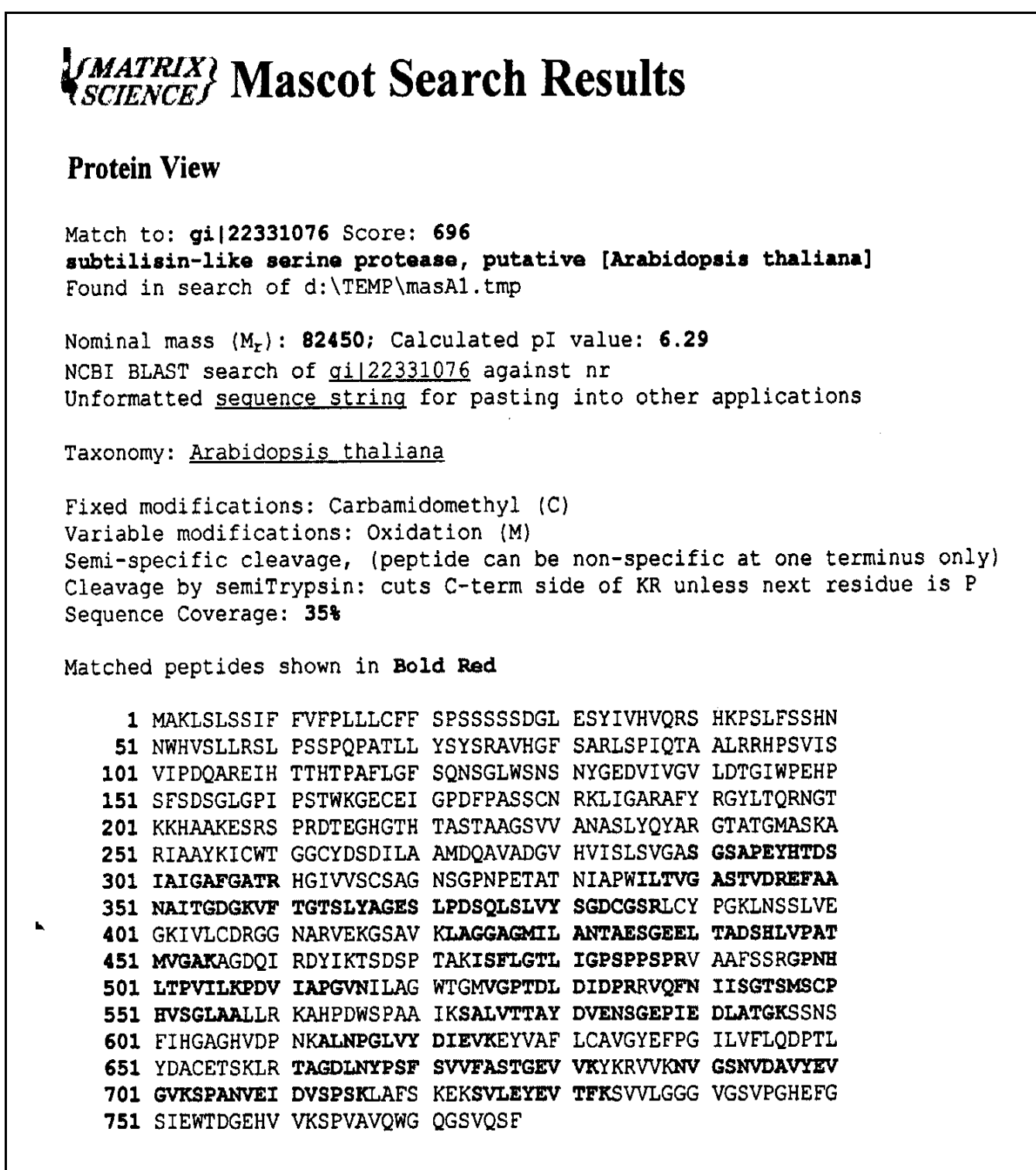

El resultado incluye la identificación del gen y propiedades de la proteína correspondiente, junto a las características del proceso de identificación (la base de datos consultada, la delimitación realizada en la búsqueda, y, en negritas, el porcentaje de la secuencia aminoacídica cubierta por los peptidos analizados). 
Localización subcelular de la actividad de la proteasa At3g14067

at3g14067 podría localizarse en distintos compartimientos de la vía secretoria. Dado que muchas proteasas tipo subtilisina se localizan en el espacio extracelular, (Siezen y Leunissen, 1997; Beers et al., 2003), el estudio de localización subcelular de la actividad de at3g14067 comenzó en el apoplasto de hojas senescentes (Fig. 4.5). Se extrajo el fluido extracelular, y se comparó con el tejido foliar remanente, postextracción. En el zimograma se observa un enriquecimiento de la actividad de at3g14067 en el fluído extracelular (FEC), que sugiriere que al menos en su forma activa, la proteasa se localiza en el apoplasto de hojas senescentes. La actividad de at3g14067 en el tejido post-extracción de FEC podría deberse a fluído extracelular remanente, o bien a una posible localización dual de la proteasa.

Fig 4.5 La actividad de las isoformas de at3g14067 se concentra en al apoplasto de hojas senescentes. En este zimograma se compara la actividad proteolítica del fluído extracelular (FEC), y del tejido luego de la extracción del fluído (T).

FEC T

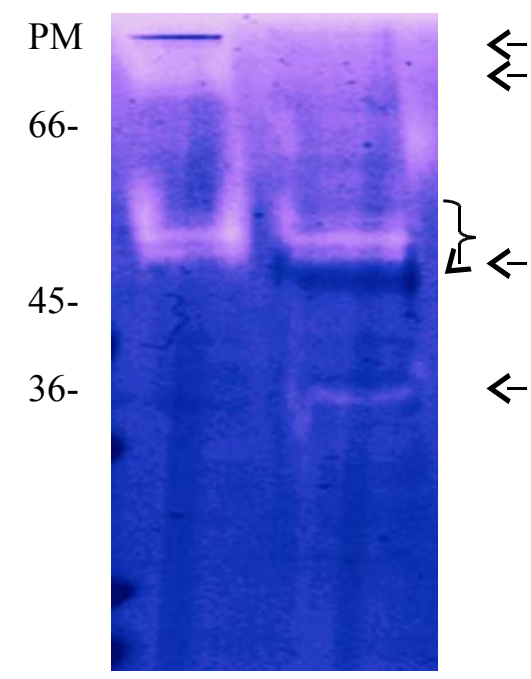

El asterisco señala la actividad de las bandas correspondientes a la proteasa subtilisina. Las flechas marcan otras proteasas activas y proteínas visibles, que aparecen solo en una de las fracciones, confirmando que no hay contaminación por proteínas intracelulares en el FEC, y que el tejido "post-extracción" carece prácticamente de este fluído. 
4.3.2 Análisis funcional de la proteasa subtilisina At3g14067 a través del uso de plantas mutantes knock out para este gen.

4.3.2.1. Selección de líneas mutantes y obtención de plantas homocigotas para la inserción de TDNA.

Se seleccionaron las líneas SALK_147962 y SALK_118286, cuyos insertos de TDNA, de 300 pares de bases, se ubican a aproximadamente 110 y 1175 bases del sitio de inicio de transcripción del gen, respectivamente (www.signal.salk.edu/cgibin/tdnaexpress). Cabe destacar que At3g14067 no presenta intrones en su secuencia. Se analizó la actividad proteolítica foliar de at3g14067 en distintas plantas de ambas líneas SALK. Las plantas deficientes en la actividad proteolítica de at3g14067 se consideraron homocigotas para la presencia del inserto de TDNA, y se seleccionaron para su reproducción y posterior análisis (Fig. 4.6). La mayor parte de los experimentos descriptos a continuación fueron realizados con la línea SALK_147962.

Fig 4.6. Selección de plantas

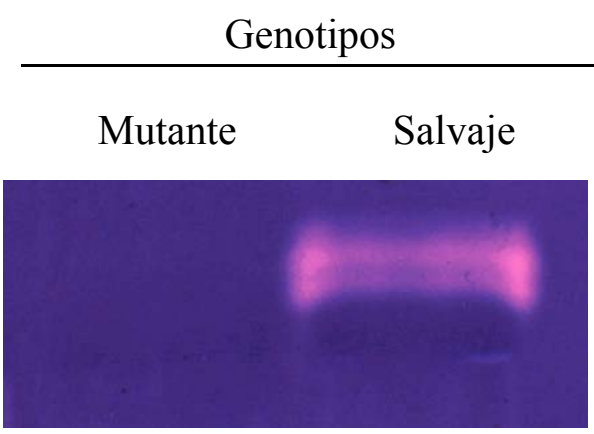
corresponden a la línea SALK_147962. 


\subsubsection{La mutación (inactivación) del gen At3g14067 afecta el ritmo de la senescencia foliar}

De acuerdo a la disminución del contenido de clorofila, la senescencia foliar se inicia en el mismo momento en plantas mutantes (KO) y salvajes (WT), aunque en plantas mutantes se observa una caída más gradual de la clorofila a lo largo del tiempo (Fig.4.7). Esta demora se ve acentuada en las hojas caulinares. En las hojas de la roseta, alrededor de un mes después de la aparición del escapo floral principal ("bolting") comenzaron a registrarse diferencias significativas entre los genotipos en el ritmo de pérdida de clorofila. A los 34 días después de "bolting", las plantas salvajes conservaban el $71 \%$ de la clorofila inicial, mientras que las plantas mutantes mantenían el $83 \%$ del valor original $(\mathrm{p}>0,05)$. No se registraron diferencias en la eficiencia fotoquímica de las hojas en ese momento $\left(\mathrm{Fv}^{\prime} / \mathrm{Fm}^{\prime}=0,61 \pm 0,03\right.$ en el WT y $0,68 \pm 0,05$ en el KO). A los 41 días de la aparición de "bolting" las plantas salvajes y mutantes conservaban el $55 \%$ y $72 \%$ de la clorofila respectivamente $(p>0,05), y$ comenzaron a observarse hojas muertas (completamente secas) en ambos genotipos. La mortalidad foliar se inició en forma simultánea en ambos genotipos, aunque al final del experimento, cuando la totalidad de las hojas examinadas de plantas salvajes estaban muertas, el 50\% de las hojas de plantas mutantes permanecían vivas.

El fenotipo asociado a la mutación de At3g14067, al igual que la actividad de esta proteasa, se acentúa conforme avanzan la senescencia foliar y el desarrollo reproductivo de la planta. Para determinar si at3g14067 participa directamente en la regulación de la senescencia foliar, o indirectamente, afectando el desarrollo reproductivo, se investigó el efecto de la mutación de At3g14067 sobre el progreso de la senescencia foliar en forma independiente al desarrollo ontogénico de la hoja. Se indujo la senescencia por incubación continua en oscuridad de hojas maduras cortadas de plantas en el estado vegetativo (Fig. 4.8). Si bien se observan ligeras diferencias en el contenido de clorofila al inicio y al final del experimento, la mutación de At3g14067 parece no afectar el ritmo de senescencia cuando es inducida en hojas maduras escindidas de la planta y colocadas en oscuridad. 
Fig. 4.7. Caída de clorofila foliar en plantas mutantes para At3g14067. WT= genotipo salvaje, $\mathrm{KO}=$ genotipo mutante (línea SALK_147962).

A) Hojas de la posición novena de la roseta.

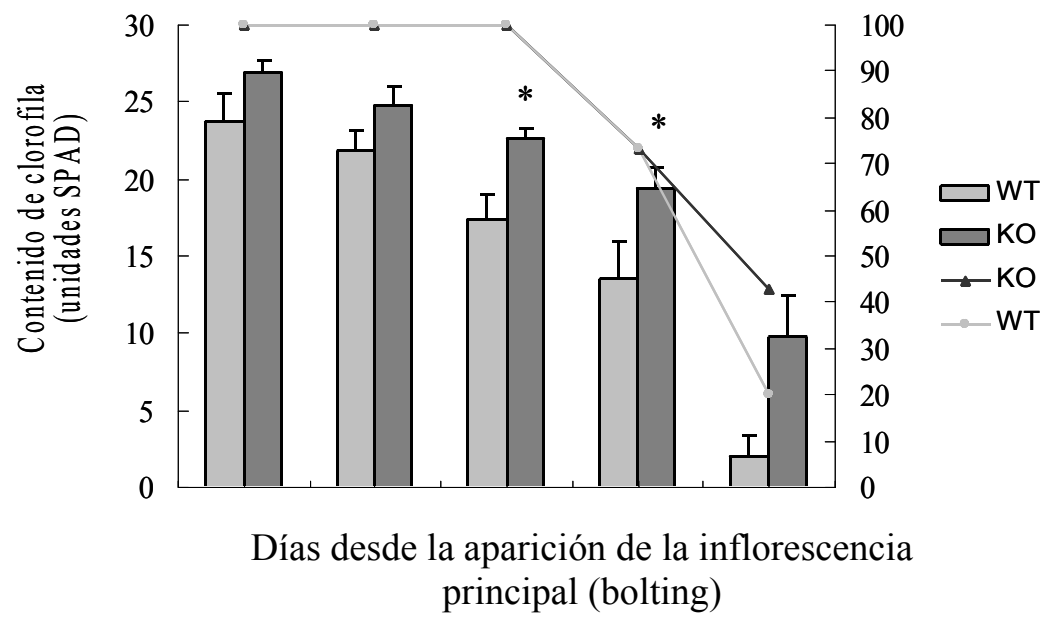

Las líneas en el gráfico representan el porcentaje de supervivencia a lo largo del tiempo de las hojas examinadas en la roseta.

B) Hojas caulinares, de la posición quinta en la inflorescencia principal.

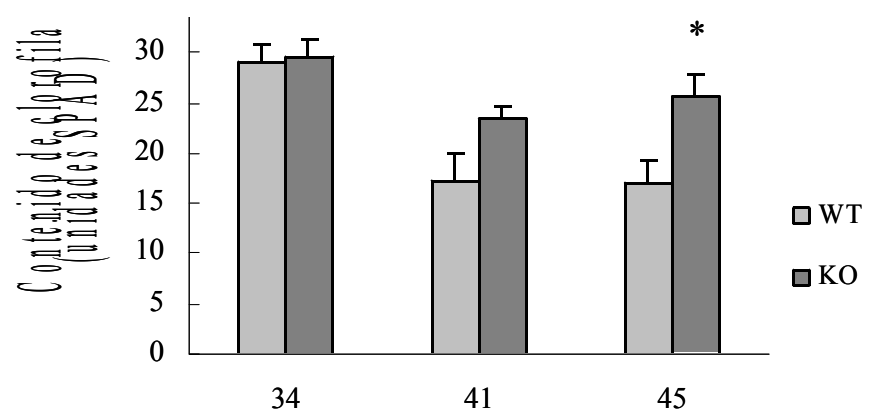

Días desde la aparición de la inflorescencia principal (bolting)

A y B: Los asteriscos representan diferencias significativas $(p>0,05)$ entre los genotipos para cada fecha. Cada valor es el promedio de cinco plantas. 
Fig. 4.8. Senescencia de hojas cortadas inducida por oscuridad en plantas mutantes para At3g14067. Se utilizaron hojas de la posición quinta desde el ápice de plantas en estado vegetativo. $\mathrm{WT}=$ genotipo silvestre, $\mathrm{KO}=$ genotipo mutante (línea SALK_147962).

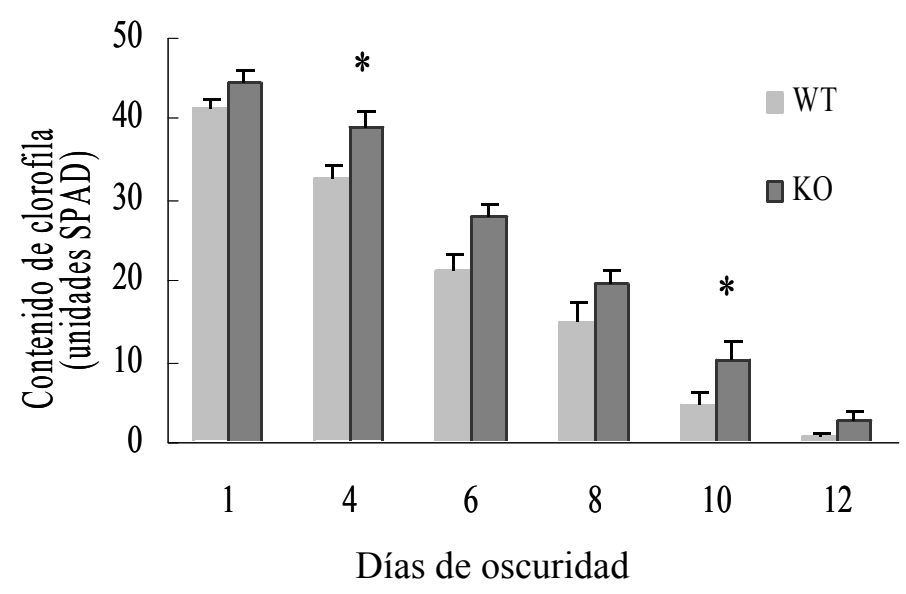

Los asteriscos representan diferencias significativas $(p>0,05)$ entre los genotipos para cada fecha. Cada valor es el promedio de cinco plantas.

4.3.2.3 La inactivación del gen At3g14067 produce plantas con estructuras reproductivas más desarrolladas.

En las plantas mutantes para el gen At3g14067 se registra una demora en el progreso de la senescencia foliar, sin embargo, llamativamente la característica más notoria asociada a la inactividad de esta proteasa subtilisina es el grado de desarrollo alcanzado por las estructuras reproductivas. En la Fig. 4.9 se muestra el fenotipo de una planta mutante creciendo a luz continua, a los 3 y 21 días después de "bolting".

En condiciones inductivas de la floración (a luz continua en los experimentos realizados en esta tesis), plantas mutantes y salvajes florecieron en forma simultánea. 
Las diferencias entre ambos fenotipos son poco notorias durante la etapa vegetativa y al comienzo de la etapa reproductiva, y se acrecientan a lo largo del desarrollo reproductivo, a medida que los ejes florales se ramifican .

Fig. 4.9 Fenotipo producto de la mutación de At3g14067. Las fotos muestran las mismas plantas, de genotipos mutante y salvaje, a los 3 días (a) y 21 días (b) después de la aparición del tallo floral principal. $\mathrm{WT}=$ planta salvaje $\mathrm{KO}=$ planta mutante (línea SALK_147962).

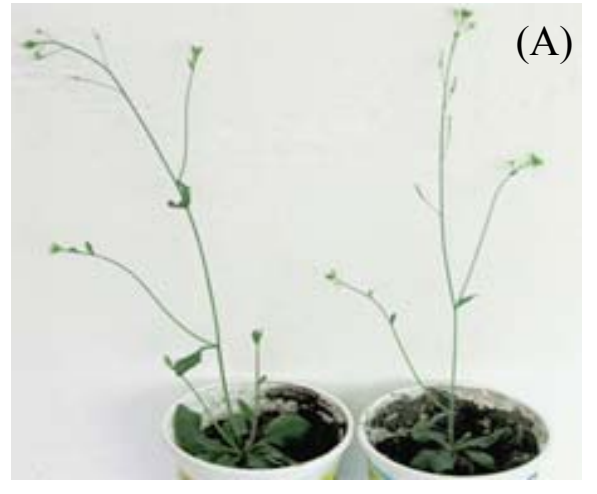

KO WT

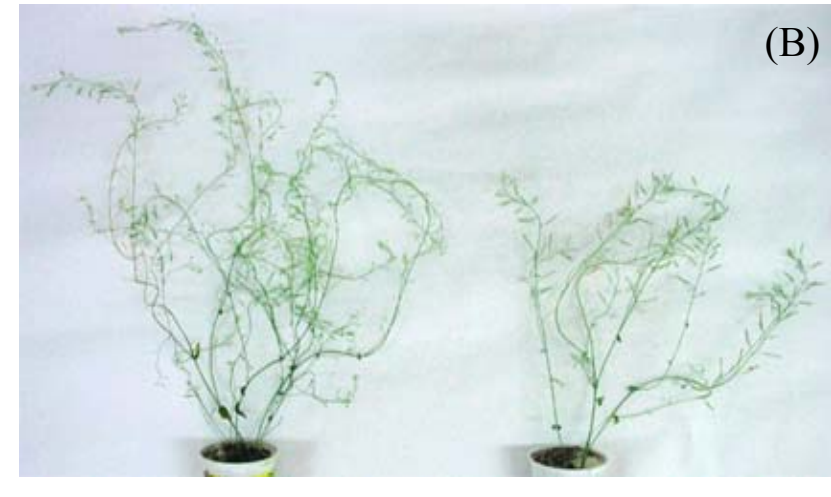

$\mathrm{KO}$

WT

Crecimiento y desarrollo de las estructuras reproductivas de plantas mutantes

El análisis del desarrollo de las estructuras reproductivas se llevó a cabo en cinco experimentos independientes, en condiciones ambientales similares. A continuación describo los resultados obtenidos en una de las cinco repeticiones realizadas de este análisis. Si bien se registraron variaciones entre repeticiones en cuanto al número de ramificaciones producidas por cada genotipo, las características del genotipo mutante y sus diferencias con el genotipo salvaje fueron reproducibles a lo largo de los cinco experimentos. 
1- La inactivación de At3g14067 genera inflorescencias con mayor cantidad de ramificaciones

En la Fig. 4.10 se muestra el número total de ramificaciones producidas por las plantas mutantes y salvajes. El número de ramificaciones total, promedio para cada planta, fue 33,4 \pm 4,7 y 48,2 $\pm 10,3$ en plantas salvajes y mutantes respectivamente $(p>0,05)$. Esta diferencia se debió principalmente a la cantidad de ramificaciones de segundo y tercer orden producidas por las plantas mutantes, significativamente mayor que en plantas salvajes $(p>0.01)$. En las plantas mutantes también se observaron con mayor frecuencia que en las plantas salvajes ramificaciones de cuarto, quinto, y sexto orden, que no se incluyeron en este análisis.

Fig. 4.10. Número total de ramificaciones producidas por planta, en los genotipos mutante y silvestre. Los valores representan el promedio de 8 plantas. El asterisco indica diferencias significativas entre los genotipos $(\mathrm{p}>0,05)$ para el número total de ramificaciones por planta. $\mathrm{WT}=$ genotipo salvaje, $\mathrm{KO}=$ genotipo mutante.

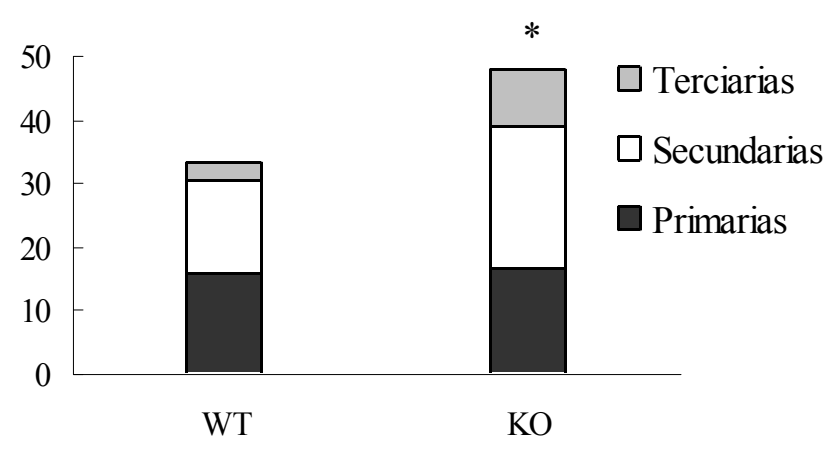

En las barras del gráfico se discrimina el número de ramificaciones de primer, segundo y tercer orden. 
2- Evolución del número de ramificaciones en el mutante de At3g14067. Desarrollo temporal de las ramificaciones

Para establecer el momento en que se inician las diferencias observadas entre las plantas salvajes y mutantes, se monitoreó el desarrollo de las inflorescencias (ramificación de los ejes de las inflorescencias) a lo largo del período reproductivo.

En plantas de Arabidopsis creciendo a luz continua, pocos días después de la aparición de la inflorescencia principal (IP, bolting), comienzan a visualizarse inflorescencias originadas en la axila de hojas de la roseta (inflorescencias axilares, (IA)), que crecen generando gran cantidad de ramificaciones. Se realizaron tres muestreos semanales desde la aparición de la IP, y un cuarto muestreo seis semanas después. En la Fig. 4.11a. se muestra el número de ramificaciones totales producidas a lo largo del tiempo por plantas mutantes y salvajes. La diferencia entre genotipos comienza a manifestarse durante las etapas iniciales del desarrollo reproductivo, y se hacen significativas durante la etapa final, seis semanas después de "bolting".

En el análisis por separado del desarrollo y ramificación de la IP se observa que la aparición de las ramificaciones, y consecuentemente, el inicio de las diferencias entre los genotipos salvaje y mutante tiene lugar más temprano en el tiempo (Fig. 4.11 a y b). A los 8 días del inicio de floración, las IP de plantas salvajes y mutantes desarrollaron 4,3 $\pm 0,2$ y $6,8 \pm 0,6$ ramas respectivamente, mientras que no se observan ramificaciones en el resto de las inflorescencias. A los 21 días de floración las ramificaciones de la IP fueron $6,6 \pm 0,8$ y 12,6 $\pm 2,4$ en plantas salvajes y mutantes respectivamente $(p>0,05)$, mientras que en el resto de las inflorescencias se registraron $10 \pm 2,0$ y $14 \pm 1,9$ ramificaciones promedio por planta salvaje y mutante, en cada caso. Tres semanas después de este muestreo, 42 días desde floración, el desarrollo de la IP de plantas salvajes alcanzó al de plantas mutantes (se registraron $12 \pm 22,9$ y $14,2 \pm 1,9$ ramificaciones en plantas salvajes y mutantes respectivamente), mientras que las ramificaciones del resto de las inflorescencias de plantas mutantes aumentan, diferenciándose de las producidas por las plantas salvajes $(17,2 \pm 1,7$ y $28,16 \pm 3,3$ ramificaciones promedio de todas las inflorescencias en las plantas salvajes y mutantes, respectivamente ).

El crecimiento anticipado de las ramificaciones en la IP de plantas mutantes está precedido por el crecimiento temprano de las hojas caulinares, en la axila de las 
cuales se originan estas ramificaciones (Fig. 4.11 b). En plantas salvajes y mutantes el número total de hojas caulinares se incrementó hasta aproximadamente 21 días después de floración, momento en que se inició la senescencia y muerte foliar. La tasa de producción de hojas en el eje reproductivo principal resultó significativamente mayor en las plantas mutantes. Las plantas salvajes produjeron un número promedio de 10 hojas caulinares durante los 8 primeros días desde el momento de floración, alcanzando un máximo de 11,1 hojas caulinares por planta 7 días después. Las plantas mutantes alcanzaron el promedio de 10 hojas por planta a los 5 días después de floración y la producción de hojas caulinares prosiguió de manera continua hasta un máximo de 18,4 hojas. En este análisis visual no se puede establecer si las diferencias observadas entre genotipos se deben a diferencias en el momento de inicio de la actividad meristemática o en la velocidad de crecimiento de las yemas laterales.

De acuerdo a los resultados obtenidos en el análisis de las plantas mutantes, la función de la proteasa subtilisina At3g14067 estaría involucrada con el desarrollo reproductivo, por lo que la denominamos SADI (subtilisin-proteasa asociada al desarrollo de las inflorescencias). 
Fig. 4.11. Desarrollo temporal de ramificaciones en plantas silvestres y mutantes para el gen At3g14067. Los valores son promedios de 8 plantas. El asterisco representa diferencias significativas entre los genotipos $(p>0,05)$. WT: genotipo salvaje, KO: genotipo mutante

A) Ramificaciones totales (producidas por todas las inflorescencias), a lo largo del desarrollo.

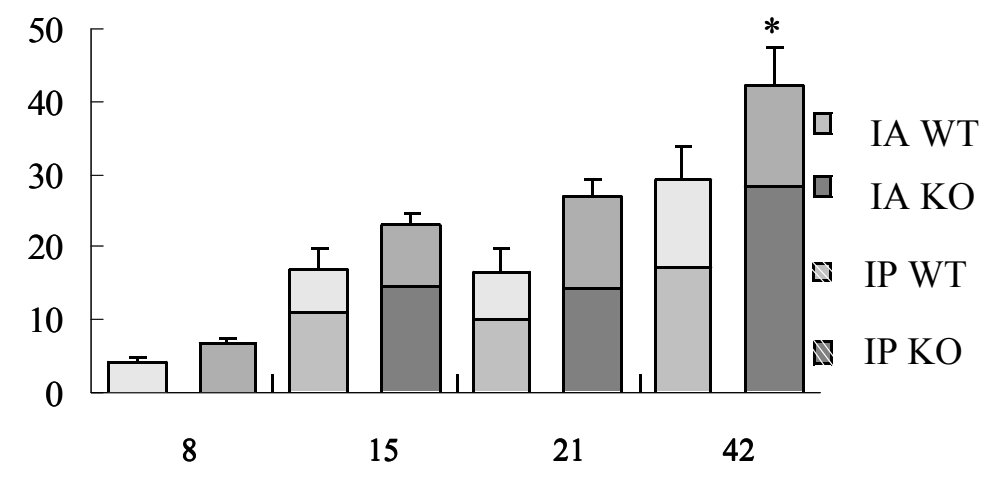

Días desde floración

En este análisis se discriminó entre las ramificaciones de la inflorescencia principal y las axilares IP: ramificaciones de la inflorescencia principal; IA: ramificaciones de inflorescencias axilares.

B) Hojas caulinares y ramificaciones de la inflorescencia principal (IP) a lo largo del desarrollo. $\mathrm{H}=$ hojas caulinares, $\mathrm{R}=$ ramificaciones

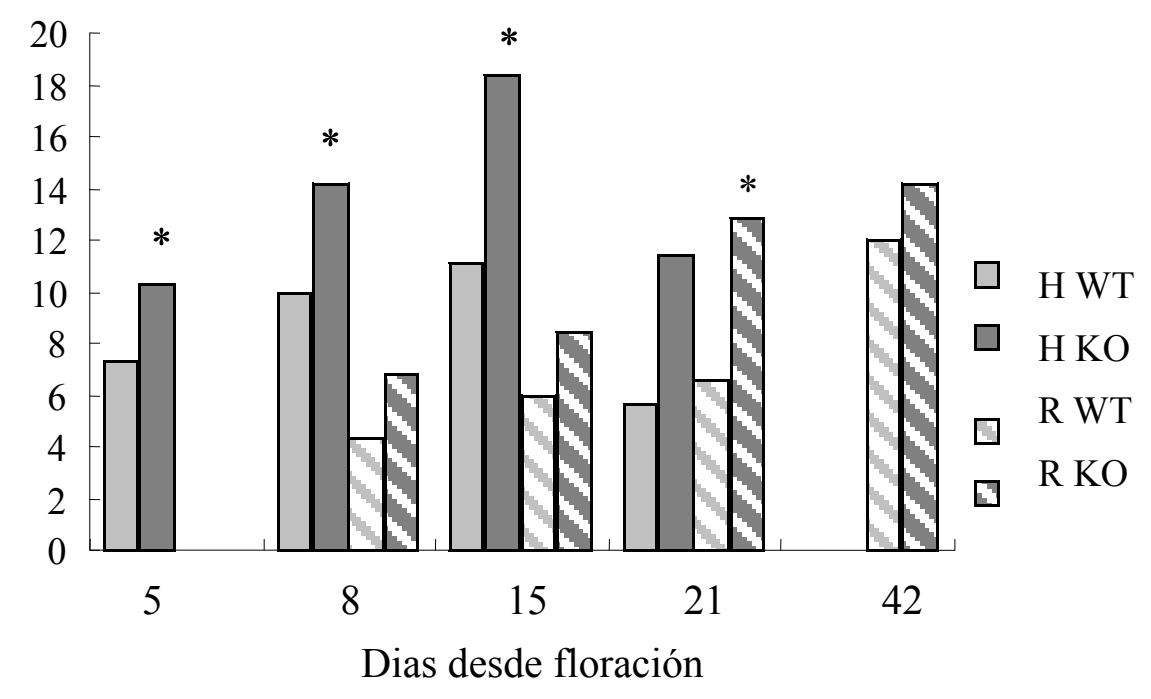


Se observaron ligeras variaciones entre distintos experimentos en la tasa de crecimiento y el patrón de ramificación de las plantas mutantes, fundamentalmente en la contribución relativa de la inflorescencia principal al total de las ramificaciones formadas por la planta. Estas ligeras variaciones se registraron entre plantas de una misma línea y entre las dos líneas mutantes de At3g14067 seleccionadas (resultados no mostrados). Más allá de estas diferencias, la mutación de SADI produce invariablemente plantas de menor carácter monopodial, más ramificadas (Tabla 4. 1). El fenotipo asociado a la mutación de SADI (i.e., mayor desarrollo de las inflorescencias que el genotipo salvaje) es sensible a la disponibilidad de luz a lo largo del desarrollo reproductivo. En condiciones de baja irradiancia el crecimiento de ramificaciones se ve notoriamente limitado en las plantas mutantes, y en estas condiciones no se encuentran diferencias entre las plantas mutantes y salvajes (Tabla $4.2)$.

Tabla 4.1. Características fenotípicas de dos líneas mutantes knock out para el gen $S A D I$. Las ligeras diferencias entre líneas son similares a las observadas entre distintos experimentos realizados con una misma línea (resultados no mostrados). Los valores representan el número de ramificaciones promedio para cada planta.

\begin{tabular}{|c|c|c|c|c|}
\hline \multirow[t]{2}{*}{ GENOTIPOS } & \multirow{2}{*}{$\begin{array}{c}\text { NÚMERO DE } \\
\text { INFLORESCENCIAS } \\
\text { AXILARES }\end{array}$} & \multicolumn{3}{|c|}{$\begin{array}{l}\text { NÚMERO DE RAMIFICACIONES } \\
\text { DESARROLLADAS }\end{array}$} \\
\hline & & IP & IA & Total \\
\hline WT & 3,8 & $8 \pm 2,5$ & $13,4 \pm 5,7$ & $21,4 \pm 6,5$ \\
\hline SALK 147962 & 5,3 & $16,5 \pm 0,8 * \Delta$ & $33,8 \pm 5,1 *$ & $50,3 \pm 3,7 *$ \\
\hline SALK 118286 & $5,8 *$ & $7,5 \pm 1,0$ & $31,3 \pm 4,7 *$ & 38,44 \\
\hline
\end{tabular}

*: diferencias significativas $(\mathrm{p}>0,05)$ entre las líneas mutantes y el genotipo salvaje $\Delta$ : diferencias significativas $(\mathrm{p}>0,05)$ entre las dos líneas mutantes. Los valores son promedios de 8 repeticiones. 
Tabla 4.2 Plasticidad de las plantas mutantes $S A D I$ en respuesta a variaciones en la irradiancia. En esta tabla se comparan el fenotipo de plantas salvajes y mutantes (SALK_147962) creciendo a alta y baja irradiancia, 180 y $50 \mu$ moles $\mathrm{m}^{-2} \mathrm{~s}^{-1}$, respectivamente.

\begin{tabular}{|c|c|c|c|}
\hline \multirow{2}{*}{ IRRADIANCIA } & \multicolumn{3}{|c|}{ NÚMERO DE RAMIFICACIONES DESARROLLADAS } \\
\hline & IP & IA & Total \\
\hline \multicolumn{4}{|l|}{ ALTA } \\
\hline WT & $12 \pm 1,9$ & $21,6 \pm 2,33$ & $33,4 \pm 2,0$ \\
\hline $\mathrm{KO}$ & $10,5 \pm 0,7 \quad \Delta$ & $39, \pm 3,63 * \Delta$ & $47,6 \pm 5,1 *$ \\
\hline \multicolumn{4}{|l|}{ BAJA } \\
\hline WT & $20,5 \pm 6,1$ & 20,7 & $41,2 \pm 3,1$ \\
\hline $\mathrm{KO}$ & $23,5 \pm 2,6$ & $28, \pm 4,7$ & $52,2 \pm 5,5$ \\
\hline
\end{tabular}

$*=$ diferencias significativas $(\mathrm{p}>0,05)$ entre plantas mutantes y salvajes creciendo a una misma irradiancia. $\Delta$ : diferencias significativas entre plantas del mismo genotipo creciendo a dos irradiancias distintas. Los valores son promedios de 8 repeticiones. La irradiancia de $50 \mu$ moles $\mathrm{m}^{-2} \mathrm{~s}^{-1}$ fue generada con tubos fluorescentes de 20 watts y de luz blanca. Para la irradiancia de $150 \mu$ moles $\mathrm{m}^{-2} \mathrm{~s}^{-1}$ se utilizaron lámparas de mercurio halogenado. 


\subsection{DISCUSION}

La combinación de geles de actividad proteolítica, técnicas de proteómica y el uso de plantas mutantes knock out por inserción de T-DNA ha permitido la detección, identificación y el posterior análisis funcional de una proteasa cuya actividad aumenta durante la senescencia foliar.

\subsubsection{Identificación y caracterización de la proteasa con actividad asociada a la senescencia, At3g14067.}

La proteasa serínica tipo subtilisina codificada por el gen At3g14067 es la responsable de gran parte de la actividad proteolítica asociada a la senescencia foliar de Arabidopsis detectable in vitro por medio de zimogramas. La presencia de al menos dos isoformas activas de At3g14067 (Figs. 4.3 y 4.4) podría deberse a que ambas actividades operan in vivo, o a que las condiciones metodológicas favorecieron la activación de una isoforma inactiva en condiciones naturales. Las actividades detectadas también podrían ser debidas a la degradación parcial de la proteasa durante alguna de las etapas experimentales. Hasta el presente At3g14067 no ha sido registrado en estudios de expresión génica (niveles de ARNm) asociada a la senescencia (Gepstein et al., 2003; Guo et al., 2004; Buchanan Wallaston, et al., 2005), lo que sugiere un posible control de la proteasa a nivel traduccional/ post traduccional, o de actividad, i.e., por compartimentalización o por la presencia de péptidos inhibidores (Yamada et al., 2001; Belenghi et al., 2003). Por ejemplo, los mayores niveles de ARNm de la proteasa subtilisina de Arabidopsis, ARA12, se detectan en hojas y tallos, mientras que por inmunodetección la proteína ara12 es localizada en tallos y silícuas, pero no en las hojas (Hamilton et al., 2003).

El péptido señal predicho en la secuencia de At3g14067 indica que la proteasa es dirigida a la ruta secretoria. A excepción de la subtilasa Kex2p residente del aparato de Golgi (Jiang y Rogers, 1999), el resto de las proteasas subtilisinas estudiadas en plantas parecen tener localización extracelular (Beers et al., 2003). Gran parte de la actividad proteolítica de at3g14067 se concentra en el apoplasto de hojas senescentes, y en menor medida en el tejido foliar post-extracción del fluído 
apoplástico (Fig. 4.6). La actividad de at3g14067 en este tejido podría deberse a un remanente de fluído apoplástico o a la ubicación dual de la proteasa. Las proteasas de tipo subtilisina de Avena, SAS1 y SAS2, se localizan constitutivamente en el interior celular y en respuesta al ataque de patógenos son liberadas al apoplasto, donde se activan (Coffen y Wolpert, 2004). Llamativamente, at3g14067 es la única proteasa subtilisina detectada en el proteoma de la vacuola central de hojas no senescentes de Arabidopsis (Carter et al., 2004), mientras que está ausente en el proteoma del apoplasto extraído de plantas jóvenes de Arabidopsis, donde se identificaron al menos otras cuatro proteasas subtilisinas (Boudart et al., 2005). Estos indicios sugieren que at3g14067 podría estar confinada en la vacuola central y ser secretada al espacio apoplástico durante la senescencia. Groover y Jones (1999) proponen un mecanismo de este tipo en el cual proteasas vacuolares son liberadas hacia el espacio extracelular como parte de la ejecución de la muerte celular programada durante la formación de elementos traqueales.

\subsubsection{La proteasa subtilisina At3g14067 está implicada en el desarrollo durante la etapa reproductiva de Arabidopsis.}

La proteasas subtilisinas de plantas se encuentran involucradas en diversos procesos, relacionados con mecanismos de defensa (Horn et al., 2005), o eventos del desarrollo tales como la formación de xilema (Zhao et al., 2000), la producción de raíces laterales (Neuteboom et al., 1999), o la germinación (Fontanini y Jones, 2002). Recientemente se detectó una proteasa tipo subtilisina asociada a la senescencia foliar (Roberts et al., 2003). Esta proteasa, cuya actividad aparece durante la senescencia foliar de trigo, se caracteriza por formar dímeros, muestra un óptimo de actividad a $\mathrm{pH} 8$, e in vitro tiene la capacidad de hidrolizar parcialmente a la enzima Rubisco, aunque se desconoce su localización subcelular y su sustrato/s in vivo (Roberts et al., 2003). Al igual que las subtilasas de animales y levaduras, las subtilisinas vegetales parecen cumplir funciones específicas y de tipo regulatorio, participando en la maduración de proteínas y péptidos señales (Matsubayashi 2003). El uso de mutantes ha permitido establecer la función de algunas proteasas subtilisinas. La subtilasa SDD1 se expresa en células "meristemoides" de la epidermis y es secretada al espacio extracelular donde participa junto al receptor con actividad quinasa TMM en la 
regulación de la formación de estomas (Berger y Altmann, 2000). Las plantas mutantes $s d d l$ desarrollan gran cantidad de estomas de distribución irregular (von Groll et al., 2002). La proteasa subtilisina ALE1 fue identificada por las anomalías y mortalidad que produce su mutación en embriones de Arabidopsis (Tanaka et al., 2001). ALE1 interactúa con ACR4, un receptor con actividad quinasa involucrado en el desarrollo de la epidermis foliar y la cutícula seminal (Watanabe et al., 2004). La inactivación de At3g14067 produce alteraciones en el desarrollo de la planta, sugiriendo que At3g14067 cumple una función específica y no redundante. Las plantas mutantes para el gen At3g14067 presentan una leve demora en el progreso de la senescencia foliar respecto del genotipo salvaje. Esta diferencia se acentúa en las brácteas $\mathrm{u}$ hojas caulinares, que se originan durante la etapa reproductiva del desarrollo, cuando se evidencian las características más notorias del fenotipo mutante. La mutación de At3g14067 genera plantas con un gran número de ramificaciones, que se desarrollan más rápido que en las plantas salvajes, si bien At3g14067 no afecta el inicio de la etapa reproductiva ("bolting"). Las diferencias entre plantas mutantes y salvajes se incrementan a lo largo del período reproductivo, y al final del ciclo el genotipo mutante ha producido mayor cantidad de ramificaciones de inflorescencias que el genotipo salvaje. De acuerdo con el fenotipo asociado a la mutación de At3g14067, denominamos a esta proteasa subtilisina asociada al desarrollo reproductivo como SADI.

La arquitectura de la parte aérea de las plantas es el resultado de la actividad del meristema apical (SAM) y de los meristemas axilares (AM), y es regulada a nivel genético, hormonal y ambiental (Mc Steen y Leyser 2005; Beveridge 2006; Casal et al., 2004). El crecimiento de hojas y entrenudos, y particularmente el inicio y actividad de meristemas axilares determinan el patrón de ramificación aérea (Grbic y Bleckeer, 1996; Grbic y Bleckeer, 2000). Las alteraciones del patrón de ramificación se deben a defectos en la iniciación, (Otsuga et al., 2001) o a la actividad de meristemas (Stingberg et al., 1999) o a ambas causas (Tantikanjana et al., 2001). De acuerdo a las observaciones realizadas en esta tesis, SADI podría afectar la actividad de los meristemas axilares, acelerando el crecimiento de yemas y de las posteriores ramas o ejes laterales, aunque es necesario contar con una caracterización histológica para establecer el posible efecto de SADI sobre el inicio de la actividad meristemática. SADI podría estar implicado en el mecanismo a través del cual las estructuras reproductivas más desarrolladas reprimen el desarrollo de nuevas 
estructuras reproductivas. El desarrollo y crecimiento de meristemas axilares es regulado por distintos tipos de señales, que operan a corta y larga distancia. El gen TERMINAL FLOWER (TF1) mantiene el carácter indeterminado de la inflorescencia del meristema apical. La sobreexpresión de TF1 da lugar a plantas de mayor desarrollo reproductivo, con más ramificaciones e inflorescencias mayores que el genotipo salvaje (Ratcliffe, et al., 1998), mientras que las plantas tfl1 solo producen una flor terminal sin desarrollo de inflorescencias ni ramificaciones axilares (Lilgjegren et al., 1999). El mecanismo sistémico que opera en el control del crecimiento de las ramificaciones aéreas integra las distintas partes de la planta, funciona a través de señales dependientes e independientes de auxinas, e involucra a una molécula inhibidora del proceso de ramificación, todavía desconocida (Bainbridge et al., 2005; Foo et al., 2005). De acuerdo a la función de otras subtilisinas, SADI podría estar implicada en la regulación sistémica del desarrollo reproductivo, por ejemplo, participando en la maduración de una señal inhibitoria de la ramificación. Los mutantes agol y sur2 desarrollan escasa y gran cantidad de raíces adventicias, respectivamente, debido a distintas alteraciones en el metabolismo de auxinas (Sorin et al., 2005), y en ambos mutantes se registró un aumento en el nivel de SADI (Sorin et al., 2005), sugiriendo que la función de SADI podría afectar procesos mediados por auxinas. La mutación de AXR1, un gen que codifica una proteína involucrada en la activación del metabolismo de auxinas (Lincoln et al., 1990; Kepinski y Lyser, 2002), da lugar a plantas insensibles a esta hormona y sumamente ramificadas (Stingberg et al., 1999), de aspecto similar al de las plantas mutantes SADI (sadi), aunque de menor estatura. SADI podría participar en la regulación del desarrollo de ramificaciones a través del mismo mecanismo de represión. Los experimentos sobre el control correlativo entre estructuras reproductivas demuestran que en Arabidopsis el aumento del número de ramificaciones reproductivas da lugar a plantas más longevas (Nooden y Penney, 2001). Los autores sugieren que esto se debe a la importancia de las estructuras aéreas de esta especie como fuente de fotoasimilados durante la etapa reproductiva, cuando la roseta se encuentra en estado senescente. La pérdida o atenuación del hábito monocárpico asociada a una mayor longevidad ha sido observada como resultado de distintas mutaciones. supershoot presenta una mutación en un citocromo P450, que produce la iniciación de gran cantidad de meristemas axilares, dando lugar a plantas sumamente ramificadas y más longevas que las plantas salvajes (Otsuga et al., 2001). 
Otro mutante con producción de ramificaciones aumentada es max2 (Stirnberg et al., 2002) que fue identificado originalmente como el mutante de senescencia demorada ore9 (Woo et al., 2001).

La mutación de SADI demora el progreso de la senescencia foliar, en forma leve en las hojas de la roseta, y más notoriamente en hojas caulinares, mientras que parece tener poco efecto en la senescencia inducida de hojas maduras colocadas en oscuridad. SADI afecta fundamentalmente el desarrollo reproductivo, promoviendo el crecimiento de ramificaciones. La falta de un fenotipo evidente en plantas mutantes creciendo a baja irradiancia sugiere que el desarrollo alcanzado por las plantas en ausencia de la actividad de SADI es limitado principalmente por la disponibilidad de recursos, y en menor grado por un control endógeno de tipo correlativo. La actividad de esta proteasa subtilisina estaría vinculada con el desarrollo ontogénico de la planta, afectando indirectamente la senescencia foliar individual. De acuerdo a estas observaciones, SADI podría estar operando en un mecanismo de finalización del desarrollo global de la planta, o senescencia monocárpica, participando en la producción/regulación de alguna señal producida hacia el final del desarrollo foliar, involucrada en la represión del desarrollo ilimitado de estructuras reproductivas. 


\section{CAPITULO 5}

Discusión General 


\subsection{DISCUSIÓN GENERAL}

La senescencia es un proceso fisiológico de autodesmantelamiento celular. Una serie ordenada y controlada de eventos puestos en marcha a nivel celular posibilitan la degradación y removilización, por parte del órgano o individuo senescente, de sus propios componentes. Esta Tesis abordó el mecanismo de proteólisis masiva que caracteriza al síndrome de la senescencia foliar, y se concentró en el estudio de las proteasas implicadas, la regulación de su actividad y su ubicación subcelular. Los aportes más relevantes de este trabajo al conocimiento de las bases mecanísticas de la senescencia foliar son los siguientes:

- La senescencia foliar de trigo, "natural" o inducida, se caracteriza por la actividad, dependiente del $\mathrm{pH}$, de un grupo de proteasas cisteínicas que están presentes en la hoja no senescente en forma inactiva (Cap. 2). Las mismas proteasas se expresan durante la senescencia foliar inducida en distintas situaciones del desarrollo (vg., senescencia monocárpica) o acelerada por distintos factores de estrés (v.g., oscuridad contínua y déficit hídrico).

- En hojas senescentes se detectó la aparición de un conjunto de estructuras de alrededor de $1 \mu \mathrm{m}$ de diámetro, de lumen ácido y naturaleza vacuolar. Estas vacuolas asociadas a la senescencia (VAS), no habían sido descriptas previamente (Cap. 3).

- Las VAS contienen la proteasa cisteínica específica de la senescencia foliar sag12, y la mayor parte de la actividad proteolítica de tipo cisteínica en general (Cap. 3).

- Una proporción de VAS contiene componentes del cloroplasto, i.e., la proteína CP-GFP y/o clorofila. Este hecho indica que, al menos en parte, la degradación masiva de proteínas plastidiales ocurre ex situ, y que las VAS están involucradas en este proceso (Cap. 3). 
- La abundancia de VAS por célula se correlaciona con el ritmo de degradación del cloroplasto en hojas donde la senescencia es modulada a través de tratamientos hormonales.

- Durante la senescencia foliar de Arabidopsis aumenta la actividad de la proteasa subtilisina SADI, de localización apoplástica y probable función regulatoria vinculada al desarrollo reproductivo, con efectos aparentemente indirectos en el progreso de la senescencia foliar individual (Cap. 4).

Los resultados obtenidos en los Capítulo 2 y fundamentalmente en el Capítulo 3 de esta Tesis demuestran que la actividad proteolítica asociada a la senescencia, en especial la de proteasas tipo cisteínicas, se localiza fuera del cloroplasto, en compartimientos de lumen ácido. Estos resultados avalan la hipótesis general de este trabajo de que la degradación masiva de proteínas durante la senescencia es ejecutada, al menos parcialmente, por proteasas extraplastidiales, y que en este proceso participan otros compartimientos subcelulares además del cloroplasto.

\subsubsection{La actividad proteolítica asociada a la senescencia se concentra en compartimientos de pH ácido, fuera del cloroplasto.}

Esta Tesis se enfocó en el estudio de las proteasas cuya actividad aparece de novo o aumenta durante la senescencia. Se ha prestado particular atención a las proteasas de tipo cisteínicas, debido al predominio de este grupo funcional en los análisis de alteraciones en los patrones de expresión génica (a nivel de ARNm) asociados el síndrome de la senescencia foliar (Buchanan-Wollaston et al., 2005). Sin embargo, la actividad proteolítica puede estar regulada a través de distintos mecanismos, además del control transcripcional (Wiederanders, et al., 2003). La existencia de niveles de regulación de proteasas posteriores a la transcripción génica motivó en gran medida el enfoque dado a este trabajo.

Los niveles estables, evaluados a través de marcación química con el inhibidor específico DCG-04, y la actividad de proteasas cisteínicas, detectada in vitro en zimogramas, aumentan durante la senescencia foliar de trigo (Cap. 2). Estos 
resultados son coincidentes con los obtenidos por van Hoorn et al., (2004) en el análisis de marcación química de proteasas cisteínicas asociadas a la senescencia de Arabidopsis, y con experimentos de actividad en gel asociada a la senescencia de Cyperus sp., Petroselinum crispum sp., y Cucumis sp._(Fischer et al., 1998; Jiang, et al., 1999; Yamauchi et al., 2002). En esta Tesis, las técnicas de marcación química y de actividad en gel revelaron un mismo patrón de proteasas cisteínicas en las hojas senescentes de trigo (Fig. 2.3, 2.4). In vitro, este grupo de proteasas es activo a $\mathrm{pH}$ inferior a 5, y su actividad aparece durante la senescencia foliar de trigo, ya sea monocárpica o desencadena por incubación en oscuridad contínua o déficit hídrico. De acuerdo a lo observado en los zimogramas, la actividad de las proteasas cisteínicas es exclusiva de hojas senescentes (S), si bien la marcación química indica que este grupo de proteasas está presente en hojas no senescentes (S), aunque sus niveles estables se incrementan conforme progresa la senescencia. La activación de proteasas preexistentes y el incremento en los niveles de su expresión podrían ser ambos mecanismos de regulación y aumento de la actividad proteolítica durante la senescencia foliar de trigo. Existen evidencias de la regulación por inhibidores endógenos de la actividad de algunas proteasas de trigo. La actividad de proteasas serínicas del apoplasto foliar de trigo se encuentra asociada a la respuesta frente a organismos fúngicos, y es regulada por un inhibidor específico (Segarra et al., 2003). Durante la senescencia floral de Dianthus sp aumenta la actividad de la proteasa cisteínica DC-CP, tanto por el incremento de su expresión génica como por la disminución de los niveles de inhibidores endógenos de esta proteasa (Sugawara et al., 2002).

En general, la actividad de proteasas cisteínicas, y en muchos casos su maduración, es dependiente del ambiente redox, y se ve favorecida a $\mathrm{pH}$ ácido (Wiederanders, et al., 2003). Las proteasas cisteínicas asociadas a la senescencia foliar de trigo requieren un $\mathrm{pH}$ menor a 5 para su detección en zimogramas. Este hecho sugiere que in vivo su actividad sería regulada por, y altamente dependiente del $\mathrm{pH}, \mathrm{y}$ por ende, del ambiente y/o compartimiento subcelular donde se encuentran. (Holwerda, et al., 1990). En las hojas senescentes de trigo las proteasas cisteínicas se localizan en la vacuola central (VC, Fig. 2.9). El aislamiento y análisis de vacuolas se realizó solo a partir de material senescente, por lo que se desconoce si las proteasas cisteínicas también se encuentran en la VC de hojas NS, donde son inactivas. Las proteasas cisteínicas podrían ingresar a la VC durante la senescencia, y ser activadas 
por el $\mathrm{pH}$ del lumen vacuolar, a través de un mecanismo similar al observado en la proteasa cisteínica RD21 (Yamada t al., 2001). Otra posibilidad es que las proteasas residan en la VC de hojas NS y su activación tenga lugar durante la senescencia, en respuesta a un cambio en el ambiente vacuolar. Un mecanismo de este tipo tiene lugar durante la germinación de semillas de cereales, donde la actividad de proteasas vacuolares en la capa de aleurona es dependiente de ligeros cambios de $\mathrm{pH}$ (Hwang et al., 2003). Para mi conocimiento, no hay registros de mediciones de $\mathrm{pH}$ vacuolar que acompañen el progreso de la senescencia foliar.

El aislamiento de VC de hojas senescentes de trigo corrobora que estas organelas se mantienen intactas durante la degradación masiva de proteínas asociada a la senescencia. La posibilidad de que las proteasas cisteínicas, u otras proteasas vacuolares asociadas a la senescencia, participen en la degradación de proteínas cloroplásticas implicaría la existencia de un mecanismo de transferencia de proteínas cloroplásticas a la VC desconocido hasta el presente.

En el análisis in vivo, por microscopía confocal, de la actividad proteolítica asociada a la senescencia foliar de Arabidopsis y tabaco se detectó un patrón completamente distinto de distribución subcelular de proteasas cisteínicas (Cap. 3). La actividad proteolítica de tipo cisteínica no se concentra en la VC, sino que aparece confinada en pequeñas vacuolas cuya aparición está estrechamente a asociada a la senescencia foliar, y que por estas características se denominaron VAS. Las VAS fueron observadas en Arabidopsis (Fig.3.1), tabaco (Fig 3.7), y soja (este resultado no corresponde a esta Tesis), indicando su participación en la senescencia foliar de distintas especies. En principio, los resultados sobre la localización subcelular de proteasas cisteínicas obtenidos en los Cap. 2 y 3 son contradictorios. Esta incongruencia podría deberse a cuestiones metodológicas, o diferencias entre especies (por ejemplo, Mono vs Dicotiledóneas). El examen de la actividad proteolítica por microscopía confocal (Cap. 3) incluyó el uso de líneas mutantes con expresión de SAG12-GFP (Arabidopsis), y con expresión CP-GFP (tabaco), motivo por el cual se utilizaron estas especies como modelo, y no trigo. El análisis in vivo de la senescencia foliar de Arabidopsis y tabaco indica que la actividad proteolítica asociada al síndrome se concentra en las VAS. Cabe la posibilidad de que las VAS fueran copurificadas con la VC de trigo en el fraccionamiento estandar de vacuola central, utilizado en el Cap. 2. Esta posibilidad explicaría la concentración de actividad proteolítica cisteínica en la fracción vacuolar, detectada durante la senescencia foliar 
de trigo. Las VAS de Arabidopsis poseen un $\mathrm{pH}$ lumenal cercano a 5, casi una unidad menor que el pH de la VC (Otegui et al., 2005), y que resulta similar al pH óptimo de actividad determinado in vitro para las proteasas cisteínicas de trigo. Chiba et al. (2003) detectaron por microscopía electrónica compartimientos de tamaño similar a las VAS, y que son exclusivos de hojas senescentes de trigo, pero se desconoce si estos compartimientos contienen actividad proteolítica. La detección y el análisis de las VAS ha quedado limitado en esta Tesis a especies dicotiledóneas. Aunque es posible que existan VAS en trigo, y que co-purificaran con la $\mathrm{VC}$, no puede descartarse que en trigo, y en otras especies monocotiledoneas la actividad proteolítica asociada a la senescencia se concentre exclusivamente en la VC, y que esta organela represente el único compartimiento celular de naturaleza lítica/ácida.

En esta Tesis se describen las VAS, una nueva clase de vacuolas presentes durante la senescencia de células fotosintéticas, y donde se concentra la mayor parte de la actividad proteolítica de tipo cisteínica e incluso serínica (Cap. 3). Las VAS fueron detectadas in vivo por microscopía confocal, por su intensa actividad proteolítica (producen la mayor señal celular de hidrólisis de los sustratos de proteasas cisteínicas y serínicas, R6502 y R6505) y por la acumulación en su interior de indicadores de compartimientos ácidos (LysoTracker Red/Rojo Neutro) (Figs. 3.1., 3.2. y 3.3.), ambas evidencias que demuestran la naturaleza lítica de las VAS. Los fluorocromos marcadores de VAS (R6502- R6505 y LysoTracker Red/Rojo Neutro) prácticamente no son detectados en la VC. La identidad vacuolar de las VAS se apoya también en que las VAS, como la VC, poseen una pirofosfatasa vacuolar (Otegui et al., 2005). Sin embargo, las VAS se distinguen claramente de la VC ya que 1- la proteasa cisteínica específica de la senescencia, sag12, se localiza en las VAS, y no en la VC (Fig.3.2) y 2- las VAS carecen de la acuaporina $\gamma \mathrm{TIP}$, característica de la vacuola central (Otegui et al., 2005). El análisis de plantas mutantes donde la expresión del gen SAG12 está bloqueada demostró que otras proteasas cisteínicas además de sag12 se localizan en las VAS.

Las VAS contienen proteasas cisteínicas y serínicas activas aunque con la metodología utilizada no fue posible distinguir si las VAS representan una población homogénea en cuanto a su carga de proteasas, o si existen distintas VAS, de acuerdo a su contenido. Por otra parte, las VAS, podrían contener otro tipo de proteasas, u otras actividades hidrolíticas (i.e., lipasas, estearasas, ARNasas). 


\subsubsection{Las VAS participan en la degradación de proteínas y otros componentes cloroplásticos}

Distintas evidencias indican que las VAS están directamente implicadas en la degradación de componentes del cloroplasto durante la senescencia: 1- la VAS son detectadas solo en hojas senescentes (Fig 3.1), 2- las VAS son exclusivas de células fotosintéticas (Fig 3.3), 3- la población celular de VAS se incrementa cuando la senescencia foliar es acelerada, v.g., mediante la aplicación de etefón e incubación en oscuridad (Fig 3.10, Tabla 3.1), 4- una proporción de la población intracelular de VAS contiene componentes del cloroplasto (Fig.3.8).

Estas observaciones fueron realizadas en células y trozos de hojas de líneas salvajes de Arabidopsis y tabaco, utilizando LysoTracker o Rojo Neutro como marcador de VAS. En las distintas muestras se detectó que algunas VAS contienen señal de fluorescencia de clorofila, o de un catabolito derivado de este pigmento. Las VAS con clorofila usualmente se disponen cercanas a los cloroplastos. Durante la senescencia foliar de líneas de tabaco que expresan GFP direccionada al cloroplasto (CP-GFP), la proteína GFP es detectada en alrededor del 60\% de las VAS, sin que se observe una tendencia particular en la distribución intracelular de VAS con GFP. En las mismas plantas, aproximadamente el $35 \%$ de las VAS contienen señal de clorofila, y el 14\% tiene señal de GFP y de clorofila. De acuerdo a estos resultados, distintos componentes cloroplásticos serían incorporados y posiblemente degradados parcial o totalmente en las VAS. La degradación de la clorofila culmina con la acumulación del catabolito NCC en la VC (Hinder et al., 1996), aunque se desconoce el/los compartimientos subcelular/es donde ocurren los pasos catabólicos intermedios, y el mecanismo de traslado e incorporación de catabolitos de clorofila (FCC, NCC u otros) a la VC. Las VAS podrían operar como parte de la vía de degradación y/o transporte de clorofila a la VC. La señal de clorofila restringida a las VAS cercanas a cloroplastos sugiere que este pigmento o su derivado es inestable en las VAS. El uso de GFP como modelo de proteína cloroplástica y su detección en las VAS sugiere que las VAS serían un compartimiento de degradación de proteínas fotosintéticas. Llamativamente, de acuerdo a la distribución intracelular de VAS con GFP y la intensidad de su señal de fluorescencia, esta proteína es sumamente estable en el 
interior lítico de las VAS. GFP podría ser degradada sólo parcialmente por las proteasas de las VAS, y aún conservar su señal.

El etefón acelera la senescencia foliar (Weaver et al., 1998). El tratamiento con etefón más oscuridad aceleró la senescencia de hojas escindidas de tabaco (de líneas salvajes y CP-GFP). Después de dos días de tratamiento, las hojas tratadas con etefón perdieron un 36\% de la clorofila, una disminución tres veces mayor que en las hojas sin tratar. Esta manipulación de la senescencia foliar y aceleración de su progreso afectó el tamaño de la población celular de VAS y su contenido relativo en componentes cloroplásticos. En las hojas donde se aceleró la senescencia con etefón, prácticamente se triplicó la población celular de VAS, el porcentaje de VAS con señal de GFP se mantuvo estable y no se registraron VAS con clorofila. La mayor inestabilidad de la señal de clorofila en las VAS se correlaciona con la marcada disminución de los niveles de este pigmento medido a nivel foliar. El progreso abrupto de la senescencia implica un aumento en la degradación de proteínas. En hojas tratadas con etefón aumentó el número de VAS, aunque la proporción de VAS con GFP se mantuvo estable. Esta observación y el hecho de que las VAS concentran la mayor actividad de proteasas en hojas senescentes sugiere que el aumento de la actividad proteolítica durante la degradación masiva de proteínas podría estar sujeta a la formación e incremento de la población de VAS, y no al aumento de la actividad proteolítica en cada VAS particular.

Tanto el origen de las VAS como su función específica en la degradación de componentes cloroplásticos, se desconoce. Compartimientos con contenidos de proteasas similares a las VAS, como los ricinosomas (Schmid et al., 2001), se originan del RE (Toyooka et al., 2000, Galili 2004). La proteasa sag12 posee señal de direccionamiento al RE (Lohman et al., 1994), aunque no se identificó ninguna otra señal de localización subcelular en su secuencia. Las VAS podrían originarse a partir del RE u otro componente del sistema de secreción. Se puede especular que las VAS posteriormente se cargarían con componentes cloroplásticos, y parte de la degradación de clorofila y proteínas cloroplásticas tendría lugar dentro de las VAS. En algunas especies se registra un transporte continuo de lípidos entre cloroplasto y el RE (Xu et al., 2003), y se han propuesto zonas de contacto entre dominios del RE y el cloroplasto como mecanismo de transferencia lipídico (Kelly y Dörmann, 2004). Los contactos RE- cloroplasto podrían ser zonas de transferencia de proteínas, o incluso ser sitios donde la identidad de las respectivas membranas (del RE y del cloroplasto) 
se modificara. Este cambio de identidad de las membranas y el reclutamiento de proteínas y otros componentes de ambos compartimientos podría ser el origen de la formación de VAS, lo que explicaría su composición híbrida.

En síntesis, el estudio in vivo realizado en esta Tesis sobre la actividad proteolítica y los procesos subcelulares asociados a la senescencia foliar condujo a la identificación de las VAS. Si bien su origen y función exacta todavía se desconoce, las VAS son una evidencia concreta de la existencia de mecanismos extraplastídicos involucrados en la degradación masiva de proteínas fotosintéticas y otras macromoléculas durante la senescencia.

\subsubsection{Proteasas con actividad asociada a la senescencia pueden cumplir otras funciones además de participar en la proteólisis masiva}

Se desconoce la función particular de casi todas las proteasas identificadas por su expresión asociada a la senescencia. Uno de los objetivos de esta Tesis era establecer el rol específico de proteasas cuya actividad se asocia, aumenta o aparece, durante la senescencia foliar (Cap. 4). La combinación de zimogramas, geles bidimensionales y espectrometría de masas permitió identificar una proteasa cuya actividad aumenta durante la senescencia foliar de Arabidopsis y que no había sido identificada previamente como asociada a la senescencia. A través del uso de las colecciones disponibles de líneas mutantes de Arabidopsis, se analizó el fenotipo de plantas mutantes para el gen correspondiente a la proteasa identificada. El desarrollo de este trabajo demuestra que es factible realizar análisis de genética reversa comenzando con la detección de actividad proteolítica. La proteasa identificada es codificada por el gen At3g14067, y corresponde al grupo mecanístico de las proteasas serínicas tipo subtilisina. Gran parte de las subtilisinas conocidas se localizan en el apoplasto, donde cumplen funciones de tipo regulatorio. Las subtilasas SDD1 y ALE participan, junto a receptores de tipo quinasa, en la regulación de la formación de estomas y de la cutícula, respectivamente (Berger y Altmann, 2000; Tanaka et al., 2001; Watanabe et al., 2004). La actividad de at3g14067, se concentra en el apoplasto de hojas senescentes (Fig 4.5), aunque se registró su presencia en la VC de hojas no senescentes (Carter et al., 2004). Llamativamente, la inactivación de At3g14067 dió lugar a plantas con un aumento del desarrollo y ramificaciones de las inflorescencias 
(Fig 4.9), razón por la cual se denominó SADI (subtilasa asociada al desarrollo de inflorescencias) a esta proteasa. Las plantas mutantes para el gen SADI muestran además una ligera demora en la senescencia foliar, más acentuada en las hojas de las inflorescencias. La localización apoplástica de sadi, y el fenotipo producto de su inactivación sugieren que esta proteasa participa en la regulación del desarrollo de estructuras reproductivas. SADI podría participar en el mecanismo de represión del desarrollo de inflorescencias, entre otros efectos, manteniendo el hábito monocárpico. La mutación de SADI retrasa la senescencia monocárpica sin afectar el momento de floración que, al menos bajo fotoperíodos inductivos (días largos), es el mismo para genotipos salvajes y mutantes. El desarrollo de inflorescencias hiper-ramificadas, observado en plantas producto de distintas mutaciones, es un carácter usualmente asociado a la senescencia monocárpica demorada (Otsuga et al., 2001; Woo et al., 2001). Estas evidencias apoyan la idea de que la senescencia monocárpica es controlada en gran medida por el cese del desarrollo global (Bleecker y Patterson, 1997). Los fenómenos de tipo correlativo parecen no tener efecto sobre la senescencia foliar individual en Arabidopsis, pero si controlarían la senescencia a nivel de la planta entera (Noodén y Penney, 2001).

El análisis de las plantas mutantes de SADI indica que esta proteasa cumple una función única, no redundante. La profundización en el estudio de su función y de la vía de regulación en la que participa contribuirá al conocimiento sobre la regulación del desarrollo reproductivo de Arabidopsis y de otras plantas.

Por otra parte, de acuerdo a estos resultados, los trabajos basados exclusivamente en mediciones de actividad hidrolítica in vitro, como los basados exclusivamente en información molecular, deben tomarse con precaución al momento de interpretar la participación o función de un gen o producto génico en un determinado proceso. En este sentido, muchos de los trabajos que son referencia en el estudio de proteasas y sus funciones deberían reverse integrando información a distintos niveles de control de la expresión (v.g., transcripcional, traduccional, posttraduccional), localización subcelular, etc.

Finalmente, en los resultados de este trabajo de Tesis asoman algunas de las múltiples funciones de las proteasas en los seres vivos. Dada la importancia central de las proteínas en la ejecución y control de todas las funciones celulares, y al mismo tiempo las cantidades masivas de importantes nutrientes que están "invertidos” en las 
proteínas de una célula, no es sorprendente que en el desarrollo de la senescencia foliar participen proteasas altamente específicas responsables de la regulación de los niveles de proteínas involucradas en la señalización y control de múltiples actividades celulares, junto con otras proteasas mucho menos específicas activas en la degradación "al por mayor" de los constituyentes celulares. 


\subsection{DIRECCIONES FUTURAS}

\subsubsection{Las VAS, su origen y participación en la degradación del cloroplasto durante la senescencia foliar}

La detección de las VAS es sin duda un avance importante en el conocimiento de los mecanismos proteolíticos celulares, y representa un nuevo punto de partida para el estudio de la degradación y el desmantelamiento del cloroplasto durante la senescencia. Los pasos próximos en este estudio deberían enfocarse a determinar el origen de las VAS, y su función en la degradación del cloroplasto. Por otra parte, hasta el momento las VAS han sido detectadas solo en especies dicotiledóneas, y resta analizar su presencia en otros grupos vegetales.

Para determinar el mecanismo de formación de las VAS, y la función que estas cumplen se requiere un enfoque multidisciplinario, que incluye determinaciones bioquímicas, la identificación de proteínas y otras macromoléculas contenidas en las VAS, y el desarrollo de experimentos in vitro e in vivo y su observación por microscopía. Algunos de los objetivos y metodologías relevantes en este contexto incluyen:

- Aislamiento y purificación de las VAS. La purificación de VAS será de gran utilidad en los estudios tanto de su origen como de su función. Por ejemplo, el análisis proteómico de las VAS permitiría identificar las proteasas, otras enzimas (v. g., lipasas, estearasas), y las proteínas del cloroplasto contenidas en las VAS. Este análisis puede complementarse con inmunodetección de proteínas (v.g., Rubisco), por Western Blot, e inmunodetección con microscopía confocal. Con la identificación de proteínas y la determinación de sus pesos moleculares reales, es decir, los que se registren en los geles 2D, se podrá estimar el grado de proteólisis de las proteínas cloroplásticas presentes en las VAS. Mediante análisis de otros tipos (v. g., cromatografía líquida de alta performance) se podrá examinar la presencia de moléculas de distinta naturaleza (v. g., pigmentos, lípidos, ácidos nucleicos) en las VAS purificadas. La identificación de enzimas y de catabolitos permitirá establecer 
los tipos y grados de hidrólisis que tienen lugar en las VAS. Se podrá determinar si las VAS funcionan como sitio de degradación total o parcial de proteínas y/o de otras macromoléculas. Por otra parte, además de la información obtenida de la secuencia aminoacídica de las proteínas identificadas por proteómica, el exámen de posibles modificaciones postraduccionales permitiría establecer el origen de las proteínas contenidas en las VAS. Por ejemplo, la detección de proteínas glicosiladas constituiría un fuerte indicio sobre la presencia en las VAS de proteínas provenientes del aparato de Golgi.

- Examinar in vivo la formación de VAS. Las VAS podrían originarse a partir de RE, del aparato Golgi, u otro componente del sistema de secreción. Esta posibilidad se puede analizar in vivo, examinando el efecto de inhibidores y desacoplantes del sistema de secreción y de formación de vesículas sobre la población estable de VAS. En esta Tesis se demostró que la aparición de VAS se induce si se acelera el progreso de la senescencia con etefón y oscuridad. Este mismo tratamiento podría utilizarse como sistema donde examinar variaciones en la aparición y/o aumento de VAS debidos a disrupciones en el sistema de secreción.

La aparición de las VAS podría implicar la formación y fusión de vesículas de distintos orígenes, i.e., del RE y plastidiales. Se han identificado proteínas cloroplásticas homólogas a proteínas implicadas en la formación y fusión de membranas del sistema de secreción citosólico (v.g., GTPasas, dinamina, Andersson y Sadelius, 2004), pero se desconoce la función de estas proteínas en el cloroplasto. Estas proteínas podrían ser necesarias para la formación de VAS. En este sentido, sería interesante examinar la formación de VAS durante la senescencia foliar de líneas mutantes para aquellas proteínas con presunta participación en la formación de vesículas cloroplásticas.

- Determinar la presencia de VAS en otros grupos vegetales. Establecer la presencia de VAS en otros grupos, v.g. monocotiledóneas, gimnospermas, pteridófitas, permitirá estimar el grado de conservación o divergencia del mecanismo de degradación del cloroplasto durante la senescencia foliar. A su vez, este estudio contribuirá a consensuar la existencia de las VAS con la información sobre el predominio de proteasas de localización vacuolar asociadas a la senescencia de distintas especies, como en el caso de trigo (Capítulo. 2 de esta tesis) 


\subsubsection{Análisis de la función específica de SADI e identificación de su/s blanco/s}

En esta Tesis se identificó a la proteasa subtilisina sadi, y se demostró, a través del análisis del fenotipo de plantas mutantes knock out para SADI, que su función es no-redundante. SADI estaría participando en un mecanismo de represión del desarrollo de inflorescencias. Este mecanismo podría ser controlado por la parte vegetativa (roseta), o ser parte de la competencia entre estructuras reproductivas. La actividad de sadi fue detectada durante la senescencia foliar, y se desconoce si la proteasa está presente en otras partes de la planta. sadi es activa en el espacio apoplástico, lo que sugiere su participación en la regulación (i.e., maduración, degradación) de algún péptido o proteína señal móvil, implicada en la comunicación entre distintas partes de la planta. La identificación del/ los blanco/s de sadi permitiría no solo determinar la función específica de esta proteasa, sino también avanzar en el conocimiento sobre los mecanismos regulatorios del desarrollo reproductivo y de la arquitectura foliar. Esto podría involucrar:

- Un análisis comparativo del proteoma del apoplasto de plantas salvajes y mutantes knock out para SADI. Por medio de este estudio se podrán examinar cambios en la composición y cantidades relativas de las proteínas extracelulares. Aquellas proteínas donde se detecten cambios, preferentemente aumentos de sus niveles estables en las plantas mutantes respecto de las salvajes, se considerarán posibles blancos de sadi.

- SADI participaría en un mecanismo de señalización. Para determinar los órganos implicados en este mecanismo se puede analizar, in vitro, la actividad de sadi en distintos órganos (v. g., ejes florales, hojas caulinares). Por otra parte, la actividad de sadi aumenta durante la senescencia foliar, aún en plantas antes de bolting. sadi podría participar en la maduración de una señal en las hojas, durante la senescencia foliar. Experimentos de injerto donde se combinen rosetas y tallos (Turnbull et al., 2002) de plantas mutantes y salvajes permitirían determinar la participación y el control por parte de la roseta sobre el cese de crecimiento y la arquitectura de la parte aérea de la planta. 
BIBLIOGRAFIA 


\section{BIBLIOGRAFIA}

Abel, S. y Glund, K., 1987. Ribonuclease in plant vacuoles: purification and molecular properties of the enzyme from cultured tomato cells. Planta 72: 71-78.

Adam, Z. y Clarke, A. K., 2002. Cutting edge of chloroplast proteolysis. Trends in Plant Sci 7: 1360-1385.

Ahmed, S., Rojo, E., Kovaleka, V., Ventataraman, S., Dombrowski, J., Matsuoka, K. y Raikhel, N., 2000. The plant vacuolar sorting receptor AtElp is involved in transport of $\mathrm{NH}_{2}$ terminal propeptide-containing vacuolar proteins in Arabidopsis thaliana. J. Cell Biol. 149: 1335-1344.

Amir-Shapira, D., Goldschmidt, D. D., y Altman, A., 1987. Chlorophyll catabolism in senescing plant tissues: In vivo breakdown intermediates suggest different degradative pathways for Citrus fruit and parsley leaves Proc. Natl. Acad. Sci. USA 84: 1901-1905.

Andersson, M. X. y Sandelius, A. S., 2004. A chloroplast- localized vesicular transport system: a bio-informatics approach. BMG Genomics 5: 40.

Baclayon, D., Matsui, T., Suzuki, H. y Kosugi, Y., 2004. Glutamine Synthetase and Glutamate Dehydrogenase in Broccoli: Changes in Activities During Postharvest Senescence of Two Cultivars Asian J. Plant Sci. 3: 120-127.

Bainbridge, K., Sorefan, K., Ward, S., y Leyser, O., 2005. Hormonally controlled expression of the Arabidopsis MAX4 shoot branching regulatory gene. Plant J. 44: $569-580$.

Bänziger, M., Edmeades, G. O., y Lafitte, H. R., 1999. Selection for Drought Tolerance Increases Maize Yields across a Range of Nitrogen Levels. Crop Sci. 30: 1035-1040.

Barrieu, F., y Chrispeels, M. J., 1999. Delivery of a Secreted Soluble Protein to the Vacuole via a Membrane Anchor Plant Physiol.. 120: 961-968.

Battchikova, N., Zhang, P., Rudd, S., Ogawa, T., y Aro, E-M., 2005. Identification of NdhL and Ss11690 (NdhO) in NDH-1L and NDH-1M Complexes of Synechocystis sp. PCC 6803. J. Biol. Chem.. 280: 2587-2595.

Battey, N. H., James, N. C., Greeland, A. J., y Brownlee, C., 1999. Exocytosis and Endocytosis Plant Cell 11: 643-659. 
Baumeister, W., Walz, J., Zühl, F. y Seemüller, E., 1998. The Proteasome: Paradigm of a Self-Compartmentalizing Protease. Cell 92: 367-380.

Bednarek, S. Y. y Raikhel, M., 1991. The Barley Lectin Carboxyl-Terminal Propeptide Is a Vacuolar Protein Sorting Determinant in Plants. Plant Cell 3: 1195 1206.

Beers, E. P., Woffenden, B. J., Zhao, Ch., 2000. Plant proteolytic enzymes: possible roles during programmed cell death. Plant Mol. Biol. 44: 399-415.

Beers, E. P., Jones, A. M., y Dickermanc, A. W., 2003. The S8 serine, C1A cysteine and A1 aspartic protease families in Arabidopsis. Phytochemistry 65: 43-58.

Belenghi, B., Acconcia, F., Trovato, M., Perazzolli, M. Bocedi, A., Polticelli, F., Ascenzi, P. y Delledonne, M., 2003. AtCYS1, a cystatin from Arabidopsis thaliana, suppress hypersensitive cell death. Eur. J. Biochem. 270: 2593-2604.

Bellis, L. D., Picciarelli, P., Pistelli, L., Alpi, A., 1990. Localization of glyoxylatecycle marker enzymes in peroxisomes of senescent leaves and green cotyledons. Planta 180: 435-439

Benbella, M. y Paulsen, G. M., 1998. Efficacy of Treatments for Delaying Senescence of Wheat Leaves: I. Senescence under Controlled Conditions. Agron J. 90:329-332.

Benedetti, C. E. y Arruda, P., 2002 Altering the Expression of the Chlorophyllase Gene ATHCOR1 in Transgenic Arabidopsis Caused Changes in the Chlorophyll-toChlorophyllide Ratio. Plant Physiol. 128: 1255-1263.

Berger, D. y Altmann, T., 2000. A subtilisin-like serine protease involved in the regulation of stomatal density and distribution in Arabidopsis thaliana. Genes \& Development 14:1119-1131.

Bethke, P. C., y Jones, R. L., 2000. Vacuoles and prevacuolar compartments Curr. Opin. Plant Biol. 3: 469-475.

Bethke, P. C., Hillemr, S. y Jones, R. 1996. Isolation of intact Protein Storage vacuoles from barley aleurone. Plant Physiol. 110: 521-529.

Beveridge, C., 2006. Axillary bud outgrowth: sending a message. Curr. Opin. Plant Biol. 9:35-40.

Beyene, G., Foyer, Ch. H. y Kunert, K. J., 2006. Two new cysteine proteinases with specific expression patterns in mature and senescent tobacco (Nicotiana tabacum L.) leaves. J. Exp. Bot. 57:1431-1443. 
Blank, A. y McKeon, T. A., 1991. Three RNases in Senescent and Nonsenescent Wheat Leaves. Characterization by Activity Staining in Sodium Dodecyl SulfatePolyacrylamide Gels. Plant Physiol. 97:1402-1408

Bleecker, A. B., Estelle, M. A., Somerville, C. y Kende, H., 1988. Insensitivity to ethylene conferred by a dominant mutation in Arabidopsis thaliana. Science 241: 1086-1089.

Bleecker, A. B. y Patterson, S. E., 1997. Last Exit: Senescence, Abscission, and Meristem Arrest in Arabidopsis Plant Cell. 9: 1169-1179.

Bleecker, A. B., 1998. The evolutionary basis of leaf senescence: method to the madness? Curr. Opin. Plant Biol. 1: 73-78.

Borrell, A., Hammer, G. y Henzell, R. G., 2000. Does Maintaining Green Leaf Area in Sorghum Improve Yield under Drought? II. Dry Matter Production and Yield. Crop Sci. 40:1037-1048.

Bottari, A., Capocchi, A., Galleschi, L., Jovopa, A. y Saviozzi, F., 1996. Asparaginyl endopeptidase during maturation and germination of durum wheat. Physiol. Plantarum 97: 475-480.

Bouché, N. y Bouchez, D., 2001. Arabidopsis gene knockout: phenotypes wanted. Curr.Opin.Plant Biol. 4:111-117.

Boudart, G., Jamet, E., Rossignol, M., Lafitte, C., Borderies, G., Jauneau, A., Esquerré-Tugayé, M.T., y Pont-Lezica, R., 2005. Cell wall proteins in apoplastic fluids of Arabidopsis thaliana rosettes: identification by mass spectrometry and bioinformatics Proteomics 5: 212-221

Bradford, M. M., 1976. A rapid and sensitive method for the quantification of microgram quantities of protein, utilization of the principle of protein dye binding. Anal Biochem 72: 248-254.

Buchanan-Wollaston, V., 1997. The Molecular biology of leaf senescence. J. Exp. Bot. 307: 181-199.

Buchanan-Wollaston, V., Page, T., Harrison, E., Breeze, E., Lim, P., Nam, H., Lin, J. Wu, S., Swidzinski, J., Ishizaki, K., y Leaver, C., 2005. Comparative transcriptome analysis reveals significant differences in gene expression and signalling pathways between developmental and dark/starvation-induced senescence in Arabidopsis. Plant J. 42: 567-585. 
Bushnell, T. P., Bushnell, D. y Jagendorf, A. T., 1993. A Purified Zinc Protease of Pea Chloroplasts, EP1, Degrades the Large Subunit of Ribulose-1,5-Bisphosphate Carboxylase/Oxygenase. Plant Physiol., 103: 585-591.

Callis, J. y Vierstra, R. D., 2000. Protein degradation in signaling. Curr Opin Plant Biol. 3:381-386.

Canetti, L., Lomaniec, E., Elkind, Y. y Lers, A., 2002. Nuclease activities associated with dark-induced and natural leaf senescence in parsley Plant Sci. 163: 873- 880.

Carter, C., Pan, S., Zouhar, J., Avila, E. L., Girke, T., y Raikhel, N. V., 2004. The Vegetative Vacuole Proteome of Arabidopsis thaliana Reveals Predicted and Unexpected Proteins. Plant Cell, 16: 3285-3303.

Casal, J., Fankhauser, Ch., Coupland, G. y Blazquez, M., 2004. Signalling for developmental plasticity. Trends in Plant Sci. 9:1360-1385.

Clarke, S. F., Jameson, P. y Downs, Ch., 1994. The influence of 6benzylaminopurine on post-harvest senescence of floral tissues of broccoli (Brassica oleracea var Italica) Plant Growth Reg. 14: 21-27.

Clarke, A. K., 2005. Plant proteases - an appetite for destruction Physiol. Plantarum 123: 359-361.

Clarke, A. K., MacDonald, T. M. y Sjögren, L. L. E., 2005. The ATP-dependent Clp protease in chloroplasts of higher plants. Physiol. Plantarum 123: 406-412.

Coffen, W. y Wolpert, T., 2004. Purification and characterization of serine porteases that exhibit caspase-like activity and are associated with programmed cell death in Avana sativa. Plant Cell 16: 857-873.

Contento, A. L., Xiong, Y. y Bassham, D. C., 2005. Visualization of autophagy in Arabidopsis using the fluorescent dye monodansylcadaverine and a GFP-AtATG8 fusion protein. Plant J. 42: 598-608.

Cooke, J. E. K., y Weih, M., 2005. Nitrogen storage and seasonal nitrogen cycling in Populus: bridging molecular physiology and ecophysiology New Phytol. 167: 1930.

Cornic, G., 2000. Drought stress inhibits photosynthesis by decreasing stomatal aperture not by affecting ATP synthesis. Trends in Plant Sci. 5: 187-188.

Coupe, A., Sinclair, B., Watson, L., Heyes, J. y Eason, J. 2003. Identication of dehydration-responsive cysteine proteases during post-harvest senescence of broccoli florets. J. Exp. Bot. 54: 1045-1056. 
Chen, Z., Ling, J. y Gallie, D., 2004. RNase activity requires formation of disulfide bonds and is regulated by the redox state Plant Mol. Biol. 55:83-96.

Chiba, A., Ishida, I., Nishizawa, N. K., Makino, A. y Mae, T., 2003. Exclusion of Ribulose-1,5-bisphosphate Carboxylase/oxygenase from Chloroplasts by Specific Bodies in Naturally Senescing Leaves of Wheat. Plant and Cell Phys. 44: 9214-9212.

Christensen, L. E., Below, F. E. y Hageman, R. H., 1981.The Effects of Ear Removal on Senescence and Metabolism of Maize. Plant Physiol. 68: 1180-1185.

Chrost, B. y Krupinska, K., 2000. Genes with homologies to known $\alpha$-galactosidases are expressed during senescence of barley leaves. Physiol. Plantarum. 110: 111119.

De, D. N., 2000. Plant Cell Vacuoles. An Introduction. Collingwood, Australia: CSIRO Publishing.

Delorme, V. G. R., McCabe, P. F., Kim, D. y Leaver, Ch., J. 2000. A Matrix Metalloproteinase Gene Is Expressed at the Boundary of Senescence and Programmed Cell Death in Cucumber. Plant Physiol.123: 917-927.

Di Sansebastiano, G. P., Paris, N., Marc-Martin, S. y Neuhaus, J. M., 2001. Regeneration of a lytic central vacuole and of neutral peripheral vacuoles can be visualized by green fluorescent proteins targeted to either type of vacuoles. Plant Physiol. 126, 78-86.

Distefano, S., Palma, J. M., Gómez, M., del Río, L. A., 1997. Characterization of endoproteases from plant peroxisomes. Biochem. J. 327: 399-405.

Doelling, J. H., Walker, J. M., Friedman, E. M., Thompson, A.R., y Vierstra, R. D., 2002. The APG8/12-activating Enzyme APG7 Is Required for Proper Nutrient Recycling and Senescence in Arabidopsis thaliana. J. Cell Biol. 277: 33105-33114.

Dominguez, F. y Cejudo, F. 1995. Pattern of endoproteolysis following wheat grain germination. Physiol. Plantarum 95: 253-259.

Drake, R., John, I., Farrell, A., Cooper, W., Schuch, W. y Grieson, D., 1996. Isolation and analysis of cDNAs encoding tomato cysteine proteases expressed during leaf senescence. Plant Mol. Biol. 30:755-767

Droillard, M. J., Bate, N. J., Rothstein, S. J. y Thompson, J. E., 1992. Active Translation of the D-1 Protein of Photosystem II in Senescing Leaves. Plant Physiol. 99: 589-594. 
Eason, J., Ryan, D. J., Watson, L. M., Hedderley, D., Christey, M. C., Braun, H. y Coupe, S. A., 2005. Suppression of the cysteine protease, aleurain, delays floret senescence in Brassica -oleracea Plant Mol. Biol. 57:645-657.

Edmeades, G. O., Bolaños, J., Chapman, S. C., Lafitte, H. R., y Bänziger, M., 1999. Selection Improves Drought Tolerance in Tropical Maize Populations I. Gains in Biomass, Grain Yield, and Harvest Index Crop Sci. 39:1306-1315.

Elbaz, M., Avni, A., y Weil, M., 2002. Constitutive caspase-like machinery executes programmed cell death in plant cells. Cell Death and Differentiation 9: 726-733.

Epimashko, S., Meckel, T., Fischer-Schliebs, E. F., Luttge, U. y Thiel, G., 2004. Two Functionally different vacuoles fro static and dynamic porpuses in one plant mesophyll leaf cell. Plant J. 37: 294-230.

Estelle, M., 2001. Proteases and cellular regulation in plants. Curr. Opin. Plant Biol. $4: 254-260$

Evans, J. R., 1988. Acclimation by the thylakoid membranes to growth irradiance and the partitioning of nitrogen between soluble and thylakoid proteins. Australian J. of Physiol.15: 93-106.

Fang, Z., Bouwkamp, J. C., y Solomos, T., 1998. Chlorophyllase activities and chlorophyll degradation during leaf senescence in non-yellowing mutant and wild type of Phaseolus vulgaris L. J. Exp. Bot. 320: 503-510.

Feller, U. y Fischer, A., 1994. Nitrogen metabolism in senescing leaves. Critical Rev. Plant Sci. 13: 241 -273.

Feys, B. J., Wiermer, M., Bhat, R. A., Moisan, L. J., Medina-Escobar, N., Neu, C., Cabral, A., Parker, J., 2005. Arabidopsis SENESCENCE-ASSOCIATED GENE101 Stabilize and Signals within an ENHANCED DISEASE SUSCEPTIBILITY1 Complex in Plant Innate Immunity. Plant Cell 17: 26012613.

Field, T. S., Lee, D. W. y Holbrook, M. N., 2001. Why Leaves Turn Red in Autumn. The Role of Anthocyanins in Senescing Leaves of Red-Osier Dogwood. Plant Physiol. 127: 566-574.

Fischer, A., Brouquisse, R., Raymond, P., 1998. Influence of senescence and of carbohydrate levels on the pattern of proteases in purple nutsedge (Cyperus rotundus). Physiol. Plantarum 102, 385-395 
Flückiger, R., De Caroli, M., Piro, G., Dalessandro, G., Neuhaus, J. M. y Di Sansebastiano, G. P. 2003. Vacuolar system distribution in Arabidopsis tissues, visualized using GFP fusion proteins. J. Exp. Bot. 54, 1577-1584.

Fontanini, D. y Jones, B. L., 2002. SEP-1-a subtilisin-like serine endopeptidase from germinated seeds of Hordeum vulgare L. cv. Morex. Planta 215: 885-893.

Foo, E., Bullier, E., Goussot, M., Foucher, F., Rameau, C. y Beveridge, C., 2005. The branching gene RAMOSUS1 mediates interactions among two novel signals and auxin in pea. Plant Cell, 17: 464-474.

Funk, V., Kositsup, B., Zhao, Ch., y Beers, E., 2002.The Arabidopsis Xylem Peptidase XCP1 Is a Tracheary Element Vacuolar Protein That May Be a Papain Ortholog. Plant Physiol. 128: 84-94.

Galili, G., 2004. ER-Derived Compartments Are Formed by Highly Regulated Processes and Have Special Functions in Plants. Plant Physiol. 136: 3411-3413.

Gan, S. y Amasino, R. M., 1995. Inhibition of leaf senescence by autoregulated production of cytokinin. Science 270: 1986-1988.

Gan, S. y Amasino, R. M., 1997. Making sense of senescence. Plant Physiol.113: 313-319.

Geisler, M., Frangne, N., Gomes, E., Martinoia, E. y Palmgren, M., 2000. The ACA4 gene of Arabidopsis encodes a vacuolar membrane calcium pump that improves salt tolerance in yeast. Plant Physiol. 124, 1814-1827.

Georgakopoulos, J. H., Sokolenko, A., Arkas, M., Sofou, G., Herrmann, R. G. y Argyroudi-Akoyunoglou, J. A., 2002. Proteolytic activity against the lightharvesting complex and the D1/ core proteins of Photosystem II in close association to thelight-harvesting complex II trimer Biochim. et Biophys. Acta 1556: 53-64.

Gepstein, S. y Thimann, K., 1980. The Role of Ethylene in the Senescence of Oat Leaves Plant Physiol. 68: 349-354.

Gepstein, S., Sabehi, G., Carp, Hajouj, T., Nesher, M. F. O., Yariv, I., Dor, Ch. y Bassani, M., 2003, Large-scale identification of leaf senescence-associated genes. Plant J. 36: 629-642.

Gepstein, S., 2004. Leaf senescence- not just a wear and tear phenomenon. Genome Biol. 5: 212.

Glathe, S., Kervivev, J., Nimtz, M., Li, G., Tobin, G., Copeland, T., Ashford, D., Wlodawer, A. y Costa, J. 1998. Transport and activation of the vacuolar aspartic 
proteinase phytepsin in barley (Hordeum vulgare). J. Biol. Chem.. 47: 3123031236.

Goulden, M. L., Munger, J. W., Fan, S. M., Daube, B. C. y Wofsy, S. C., 1996. Exchange of carbon dioxide by a deciduous forest: Response to interannual climate variability. Science 271:1576-1578.

Grbic, V. y Bleckeer, A., 1995. Ethylene regulates the timing of leaf senescence in Arabidopsis. Plant J. 8: 595-602.

Grbic, V. y Bleckeer, A., 1996. An altered body plan is conferred on Arabidopsis plants carrying dominant alleles of two genes. Development 122, 2395-2403

Grbic, V. y Bleckeer, A., 2000. Axillary meristem developent in Arabidopsis thaliana. Plant J. 21: 215-223.

Grbic, V., 2003. SAG2 and SAG12 protein expression in senescing Arabidopsis plants. Physiol. Plantarum 11: 263- 268.

Green, P., 1993. Control of mRNA Stability in Higher Plants. Plant Physiol. 102: 10651070.

Greenbaum, D., Medzihradszky, K., Burlingame, A. y Bogyo, M., 2000. Epoxide electrophiles as activity-dependent cysteine protease profiling and discovery tools. Chem. \& Biol. 7:569-581.

Groover, A. y Jones, A. M., 1999. Tracheary Element Differentiation Uses a Novel Mechanism Coordinating Programmed Cell Death and Secondary Cell Wall Synthesis. Plant Physiol. 119: 375-384.

Grudkowska, M. y Zagdańska, B., 2004. Multifunctional role of plant cysteine proteinases. Acta Biochim. Polon. 51: 609-654.

Guiamét, J. J., Schwartz, E., Pichersky, E. y Noodén, L. D., 1991. Characterization of Cytoplasmic and Nuclear Mutations Affecting Chlorophyll and ChlorophyllBinding Proteins during Senescence in Soybean. Plant Physiol. 96: 227-231.

Guiamét, J. J., Pichersky, E., y Noodén, L. D., 1999. Mass exodus from senescing soybean chloroplasts. Plant Cell Physiol. 40: 986-992.

Guiamét, J. J., Tyystjärvi, E., Tyystjärvi, T., John, I., Kairavuo, M., Pichersky, E. y Noodén, L. D., 2002. Photoinhibition and loss of photosystem II reaction center proteins during senescence of soybean leaves. Enhancement of photoinhibition by the "stay-green" mutation cytG. Physiol. Plantarum. 115: 468-478.

Guo, Y., Cai, Z. y Gal., S., 2004. Transcriptome of Arabidopsis leaf senescence. Plant, Cell and Environment 27: 521-549. 
Gygi, S. P., Rochon, Y., Robert Franza, B., y Aerersold, R., 1999. Correlation between protein and mRNA abundance in yeast. Mol. \& Cell Biol. 19: 1720-1730.

Hadfield, K. y Bennett, A. B., 1997. Programmed senescence of plant organs. Cell Death and Differentiation 4: 662-670.

Halls, C., Rogers, S. W., y Rogers, J. C., 2005.Purification of a proaleurain maturation protease. Plant Science 168:1267-1279.

Hamilton, J. M. U., Simpson, D. J., Hyman, S. C., Ndimba, B. K., y Slabas, A. R., 2003. Ara12 subtilisin-like protease from Arabidopsis thaliana: purification, substrate specificity and tissue localization. Biochem. J. 370: 57-67.

Hanaoka, H., Noda, T., Shirano, Y., Kato, T., Hayashi, H., Shibata, D., Tabata, S., y Ohsumi,Y., 2002. Leaf Senescence and Starvation-Induced Chlorosis Are Accelerated by the Disruption of an Arabidopsis Autophagy Gene. Plant Physiol. 129: 1181-1193.

Hatsugai, N., Kuroyanagi, M., Yamada, K., Meshi, T., Tsuda, S., Kondo, M., Nishimura, M. y Hara-Nishimura, I., 2004. A Plant Vacuolar Protease, VPE, Mediates Virus-Induced Hypersensitive Cell Death. Science 305: 855- 858.

He, Y., Tang, W., Swain, J. D., Green, A. L., Jack, T. P. y Gan,S., 2001. Networking Senescence-Regulating Pathways by Using Arabidopsis Enhancer Trap Lines. Plant Physiol. 126: 707-716.

He, P., Osaki, M., Takebe, M., Shinano, T. y Wasaki, J., 2005. Endogenous hormones and expression of senescence-related genes in different senescent types of maize. J. Exp. Bot. 56:1117-1128.

Hensel, L., Grbic, V., Baumgarten, D. y Bleecker, A., 1993. Developmental and AgeRelated Processes That lnfluence the Longevity and Senescence of Photosynthetic Tissuesin Arabidopsis. Plant Cell, 5: 553-564.

Hensel, L., Nelson, M. A., Richmond, T. A. y Bleecker, A. B., 1994. The Fate of Inflorescence Meristems Is Controlled by Developing Fruits in Arabidopsis. Plant Physiol. 106: 863-876.

Hikosaka, K., 2005. Leaf Canopy as a Dynamic System: Ecophysiology and Optimality in Leaf Turnover. Annals of Botany 95: 521-533.

Hinder, B., Schellenberg, M., Rodoni, S., Ginsburg, S., Vogt, E., Martinoia, E., Matile, P. y Hörtensteiner, E., 1996. How Plants Dispose of Chlorophyll Catabolites J. Biol. Chem. 271: 27233-27236. 
Hirel, B. y Gallais, A., 2006. Rubisco synthesis, turnover and degradation: some new thoughts on an old problem. New Phytol. 169: 443-448.

Hoagland, R. y Arnon, I. 1950. The water culture method for growing plants without soil. Circ Calif Agric. Exp. Sta No 347.

Hoch, W. A., Singaas, E. y Mc Corwn, B. H., 2003. Resorption Protection. Anthocyanins Facilitate Nutrient Recovery in Autumn by Shielding Leaves from Potentially Damaging Light Levels. Plant Physiol. 133: 1296-1305.

Holwerda, B. C., Galvin, N. J., Baranski, T. y Rogers, J. C., 1990. In Vitro Processing of Aleurain, a Barley Vacuolar Thiol Protease. Plant Cell 2: 91-106.

Holwerda, B., Padgettyba, S. y Rogersaibi, J. C. 1992. Proaleurain Vacuolar Targeting is Mediated by Short Contiguous Peptide Interactions. Plant Cell 4: $307-$ 318.

Horn, M., Patankar, A. G., Zavala, J. A., Wu, J., Doleckova-Maresova, L., Vujtechova, M., Mares, M. y Baldwin, I. T., 2005. Differential Elicitation of Two Processing Proteases Controls the Processing Pattern of the Trypsin Proteinase Inhibitor Precursor in Nicotiana attenuate. Plant Physiol. 139: 375-388.

Hörtesnsteiner, S. y Feller, S., 2002. Nitrogen metabolism and remobilization during senescence J. of Exp. Bot. 53: 927-937.

Hörtensteiner, S., 2006. Chlorophyll Degradation During Senescence Ann. Rev. Plant Biol. En prensa.

Huber, S. C. y Hardin, S. C., 2004. Numerous posttranslational modifications provide opportunities for the intricate regulation of metabolic enzymes at multiple levels Curr Opin Plant Biol. 7:318-22.

Hugueney, P., Bouvier, F., Badillo, A., D'harlingue, A., Kuntz, M. y Camara, B., 1995. Identification of a plastid protein involved in vesicle fusion and/or membrane protein translocation (protein insertion machinery) Proc. Natl. Acad. Sci. USA 92: 5630-5634.

Hwang, Y., Bethke, P. C., Guble, F. y Jones, R., 2003. cPrG-HCl a potential $\mathrm{H}^{+} / \mathrm{Cl}$ symporter prevents acidification of storage vacuoles in aleurone cells and inhibits GA-dependent hydrolysis of storage protein and phytate. Plant J. 35: 154-163.

Inada, N., Kuroiwa, H., Kuroiwa, T., 1998. Three-dimensional analysis of the senescence program in rice (Oryza sativa L.) coleoptiles. Investigations by fluorescence microscopy and electron microscopy. Planta 206: 585-597. 
Inskeep, W. P. y Bloom, P.R., 1985. Extinction coefficients of chlorophyll a and b in N,N-dimethylformamide and 80\% acetone. Plant Physiol. 77: 483-485.

Jacob-Wilk, D., Holland, D., Goldschmidt, E., E., Riov, J. y Eyal, Y., 1999. Chlorophyll breakdown by chlorophyllase: isolation and functional expression of the Chlasel gene from ethylene-treated Citrus fruit and its regulation during development. Plant J. 20, 653-661.

Jiang, W. B., Lers, A., Lomaniec, E. y Aharoni, N., 1999. Senescence-related serine protease in parsley. Phytochemistry 50: 377-382.

Jiang, L. y Rogers, J.C., 1999. Functional analysis of a Golgi-localized kex2p-like protease in tobacco suspension culture cells. Plant J. 18: 22-33.

Jing, H. Ch., Schippers, J. H. M., Hille, J.y Dijkwel, P.P., 2002. Arabidopsis onset of leaf death mutants identify a regulatory pathway controlling leaf senescence. Plant J. 32: 51-63.

Jing, H. Ch., Schippers, J. H. M., Hille, J.y Dijkwel, P. P., 2005. Ethylene-induced leaf senescence depends on age-related changes and OLD genes in Arabidopsis $J$. Exp. Bot. 56: 2915-2923.

John, I., Drake, R., Farrell, A., Cooper, W., Lee, P., Horton, P. y Grierson, D., 1995.

Delayed leaf senescence in ethylene-deficient ACC-oxidase antisense tomato plants: Molecular and physiologicalanalysis. Plant J. 7: 483-490.

Jones, M. L., Larsen, P., B. y Woodson, W. R., 1995. Ethylene-regulated expression of a carnation cysteine proteinase during flower petal senescence. Plant. Mol. Biol. 28: $505-512$

Kaup, M. T., Froese, C. D. y Thompson, J. E., 2002. A Role for Diacylglycerol Acyltransferase during Leaf Senescence Plant Physiol. 129: 1616-1626.

Kato, Y., Murakami, S., Yamamoto, Y., Chatani, H., Kondo, Y., Nakano, T., Yokota; A.y Sato, F., 2004. The DNA-binding protease, CND41, and the degradation of ribulose-1,5-bisphosphate carboxylase/oxygenase in senescent leaves of tobacco. Planta 220: 97-104.

Kawaguchi, R., Williams, A. J., Bray, E. A. y Bauley-Serres, J., 2003. Water-deficitinduced translational control in Nicotiana tabacum Plant, Cell and Environ. 26: 221-229.

Kelly, A. A. y Dörmann, P., 2004. Green light for galactolipid trafficking Cur. Opin. Plant Biol. 7: 262-269. 
Kepinski, S., y Leyser, O., 2002. Ubiquitination and Auxin Signaling: A Degrading Story. Plant Cell, S81-S85.

Khanna-Chopra, R., Srivalli, B. y Ahlawat, Y. S., 1999. Drought induces many formas of cystein proteasas not observed during natural senescence. Biochem. \& Biophys. Res. Común. 255: 324-327.

Kidd, D., Liu, Y. y Cravatt, B. F., 2001. Profiling Serine Hydrolase Activities in Complex Proteomes. Biochemistry 40: 4005-4015.

Kinoshita, T., Yamada, K., Hiraiwa, N., Kondo, M., Nishimura, M. y HaraNishimura, I. 1999. Vacuolar processing enzyme is up-regulated in the lytic vacuoles of vegetative tissues during senescence and under various stress conditions. Plant J. 19: 43-53.

Kleber-Janke, T. y Krupinska., K., 1997 Isolation of cDNA clones for genes showing enhanced expression in barley leaves during dark-induced senescence as well as during senescence under field conditions Planta 203: 332-340.

Kocks, Ch., Maher, R., Overkleeft, Wang, E. W., Lackshamanan, K., LennonDumenil, A. M., Ploeg, H. L. y Kesseler, B., 2003. Functional proteomics of the active cysteine protease content in Drosophila S2 cells. Mol. \& Cellular Proteomics, 11: 1188-1197.

Köhler, R. H, Cao, J., Zipfel, W. R., Webb, W. W. y Hanson, M. R., 1997. Exchange of protein molecules through connections between higher plant plastids. Science 276: 2039-2042.

Koizumi, M., Yamaguchi-Shinozaki, K., Tsuji, H. y Shinozaki, K., 1993. Structure and expression of two genes that encode distinct drought-inducible cysteine proteinasesin Arabidopsis thaliana. Gene 129: 175-182.

Kokubun, N., Ishida, H., Makino, A., y Mae, T., 2002. The Degradation of the Large Subunit of Ribulose-1,5-bisphosphate Carboxylase/oxygenase into the $44-\mathrm{kDa}$ Fragment in the Lysates of Chloroplasts Incubated in Darkness Plant Cell Physiol. 43: 1390-1395.

Kuroda, M., Kiyosaki,T., Matsumoto, I., Misaka, S.A. y Abe, K., 2001. Molecular cloning, caracterization, and expresión of wheat cystatins. Biosci. Biotechnol. Biochem. 65: 22-28. 
Kwok, E. Y. y Hanson, M. R., 2004. GFP-labelled Rubisco and aspartate aminotransferase are present in plastid stromules and traffic between plastids. $J$. Exp. Bot. 55: 595-604.

Laemmli, U. K., 1970. Cleavage of Structural Proteins during the Assembly of the Head of Bacteriophage T4. Nature 227: 680-685.

Lam, E., 2005. Vacuolar proteases livening up programmed cell death.Trends in Cell Biol. 15: 124-126.

Larsen, M. R. y Roepstorff, P., 2000. Mass spectrometric identification of proteins and characterization of their post-translational modifications in proteome analysis. J. Anal. Chem. 366: 677-690.

Lavoisier, A. L., 1789. Traité élémentaire de chimie, Paris, Cuchet.

Lawlor, D.W., 2002. Carbon and nitrogen assimilation in relation to yield: mechanisms are the key to understanding production systems. J. Exp. Bot. 370: 773- 78

Lee, A. G., 2000. Membrane lipids: it's only a phase. Curr Biol 10: 377-379.

Lee, D. W., O'Keefe, J., Holbrook, M. N. y Field, T. S., 2003. Pigment dynamics and autumn leaf senescence in a New England deciduous forest, eastern USA Ecological Res. 18: 677-694.

Lers, A., Khalchitski, A. A., Lomaniec, E. A. y Burd, S. A., 1998. Senescenceinduced RNases in tomato Plant Mol. Biol. 36: 439-449, 1998. 439

Li, J., Lease, K. A., Tax, F. E. y Walker, J., 2001. BRS1, a serine carboxypeptidase, regulates BRI1signaling in Arabidopsis thaliana. Proc Natl Acad Sci USA 8: 59165921

Liljegren, S. J., Gustafson-Brown, C., Pinyopich, A., Ditta, G. S., y Yanofsky, M. F., 1999. Interactions among APETALA1, LEAFY, and TERMINAL FLOWER1 Specify Meristem Fate Plant Cell, 11: 1007-1018.

Lim, P. O., Woo, H. R. y Nam, H. G., 2003. Molecular genetics of leaf senescence in Arabidopsis. Trends in Plant Sci. 8: 272-278.

Lincoln, C., Britton, J. H. y Estelle, M., 1990. Growth and Development of the axrl Mutants of Arabidopsis. Plant Cell 2: 1071-1080. 
Liu, Y., Dammann, Ch. y Bhattacharyya, M. K., 2001. The Matrix Metalloproteinase Gene GmMMP2 Is Activated in Response to Pathogenic Infections in Soybean. Plant Physiol, 127: 1788-1797.

Lohman, K., Gan, S., John, M. C. y Amasino, R., 1994. Molecular análisis of natural leaf senescence in Arabidopsis thaliana. Physiol. Plantarum. 92: 322-328.

López-Otín, C., y Overall, Ch. M., 2003. Protease Degradomics: A new challenge for proteomics Nature Reviews 3: 509-519.

Maeshima, M., 1992. Characterization of the major integral protein of vacuolar membrane. Plant Physiol. 98: 1248-1254.

Martínez, D. E. y Guiamét, J. J., 2004. Distortion of the SPAD 502 chlorophyll meter readings by changes in irradiance and leaf water status. Agronomie 24: 4146.

Martínez, D. E., Luquez, M. V., Bartoli, C. G. y Guiamét, J. J., 2003. Persistence of photosynthetic components and photochemical efficiency in ears of water-stressed wheat (Triticum aestivum L.). Physiol. Plantarum 119: 519-525.

Martré, P., Porter, J. R., Jamieson, P. D. y Triboï, E., 2003. Modeling Grain Nitrogen Accumulation and Protein Composition to Understand the Sink/Source Regulations of Nitrogen Remobilization for Wheat Plant Physiol. 133: 1959-1967.

Marty, F., 1999. Plant Vacuoles. Plant Cell, 11, 587-599.

Masclaux, S., Veladier, H. M., Brigière, N., Gudry, J-F. y Hirel, B., 2000. Characterization of the sink/sourse transition in tobaco (Nicotiana tabacum.L) shorts in relation to nitrogen management and leaf senescence. Planta 211: 510518.

Matile, P. y Winkenbach, F., 1971. Function of lysosomes and lysosomal enzymes in the senescing corolla of the morning glory (Ipomoea purpurea). J Exp Bot 22: 759771

Matile, P., 1975. The Lytic Compartment of Plant Cells. Wien, Germany: SpringerVerlag.

Matile, P., Ginsburg, S., Schellenberg, M. y Thomas, H., 1988. Catabolites ofchlorophyll in senescing barley leaves are localized in the vacuoles of mesophyll cells. Proc Natl Acad Sci USA 85: 9529-9532. 
Matile, P. y Schellenberg, M., 1996. The cleavage of pheophorbide a is located in the envelope of barley gerontoplasts. Plant Physiol. Biochem. 34: 55-59.

Matile, P., Hörtesnsteiner, S. y Thomas, H., 1999. Chlrophyll degradation. Annu Rev Plant Physiol Plant Mol Biol 50: 67-95.

Matile, P., 2001. Senescence and cell death in plant development. En Regulation of Photosynthesis. E.M. Aro y B. Anedrsson (Eds.) pp 277-296. Kluwer. Netherland.

Matsubayashi, Y., 2003. Ligand-receptor pairs in plant peptide signaling. J. of Cell Sci. 116: 3863-3870.

McSteen, P. y Leyser, O., 2005. Shoot Branching. Ann. Rev. Plant Biol. 56:353-74.

Méchin, V., Consoli, L.; Le Guilloux, M. y Damerval, C., 2003. An efficient solubilization buffer for plant proteins focused in immobilized $\mathrm{pH}$ gradients Proteomics 3: 1299-1302.

Miller, B. y Huffaker, R. C. 1985. Differential Induction of Endoproteinases during Senescence of Attached and Detached Barley Leaves. Plant Physiol, 78: 442-446.

Moberg, P., Ståh, A., Bhushan, S. y Wright, S. J., 2003. Characterization of a novel zinc metalloprotease involved in degrading targeting peptides in mitochondria and chloroplasts Plant J. 36:616-628.

Moon, J., Parry, G. y Mark, E., 2004. The Ubiquitin-Proteasome Pathway and Plant Development. Plant Cell 16: 3181-3195

Morris, K., Thomas, H. y Rogers, L., 1996. Endopeptidases during the development and senescence of Lolium temulentum leaves. Phytochemistry, 41: 377-384.

Mündermann, L., Erasmus, Y., Lane, B., Coen, E., y Prusinkiewicz, P., 2005. Quantitative Modeling of Arabidopsis Development Plant Physiol. 139: 960-968.

Mutlu, A. y Gal., S., 1999. Plant aspartic proteinases: enzymes on the way to a function Physiol. Plantarum 105: 569-576

Nakabayashi, K., Ito, M., Kiyosue, T., Shinozaki, K. y Watanabe, A., 1999. Identification of $c l p$ genes expressed in senescing Arabidopsis leaves. Plant Cell Physiol. 40: 504-514.

Nakano, T., Murakami, S., Shoji, T., Yoshida, S., Yamada, Y. y Sato, F., 1997. A novel protein with DNA binding activity from tobacco chloroplast nuclei. Plant Cell 9: 1673-1682.

Nakano, T., Nagata, N., Kimura, T., Sekimoto, M., Kawaide, H., Merakam, S., Kaneko, Y., Matsushima, H., Kamiya, Y., Sato, F. y Yoshida, S., 2003. CND41 
chloroplast nucleoid protein thatregulates plastid development, causes reduced gibberellin contentand dwarfism in tobacco. Physiol. Plant 117:130-136.

Nakaune, S., Yamada, K., Kondo, M., Kato, T., Tabata, S., Nishimura, M. y HaraNishimuraa, I. 2005. A Vacuolar Processing Enzyme, $\gamma$ VPE, Is Involved in Seed Coat Formation at the Early Stage of Seed Development. Plant Cell, 17: 876-887.

Navarre, D. A. y Wolpert, T. J., 1999. Victorin Induction of an Apoptotic/Senescence-like Response in Oats Plant Cell 11: 237-250.

Neuteboom, L. W., Veth-Tello, L. M., Clijdesdale, O. R., Hooykaas, P. J .J. y van der Zaal, B. J., 1999. A Novel Subtilisin-like Protease Gene from Arabidopsis thaliana is Expressed at Sites of Lateral Root Emergence. DNA Research 6: 13-19.

Noh, Y., Quirino, F. B. y Amasino, R., 2004. Senescence and genetic engineering. En Plant Cell Death Process. L. Noodén (Ed.) pp 91-100. Elsevier Academic Press. MI. USA

Noodén, L. D., 1988. Whole Plant Senescence. En Senescence and Aging in Plants, L. D. Noodén y A.C. Leopold (Eds) pp 392-427. Academic Press. San Diego, CA, USA.

Noodén, L. D. y Guiamét, J. J., 1989. Regulation of assimilation and senescence by the fruit in monocarpic plants. Physiol Plant 77: 267-274.

Noodén, L. D., Guiamét, J. J., y John, I., 1997. Senescence mechanisms. Physiol. Plant. 101:746-753.

Noodén, L. D, y Penney, J. P., 2001. Correlative controls of senescente and plant death in Arabidpopsis thaliana (Brassicaceae). J. Exp. Bot. 364: 2151-2159.

Noodén, L. D., Guiamét, J. J. y John, I., 2004. Whole Plant Senescence. En Plant Cell Death Process. L. Noodén (Ed.) pp 19-31. Elsevier Academic Press. MI. USA.

Nühse, S. T., Stensballe, A., Jensen, O. N., y Pecka, S. C., 2004. Phosphoproteomics of the Arabidopsis Plasma Membrane and a New Phosphorylation Site Database. Plant Cell 16: 2394-2405.

Obara, K., Kuriyama, H. y Fukida, H., 2001. Direct Evidence of Active and Rapid Nuclear Degradation Triggered by Vacuole Rupture during Programmed Cell Death in Zinnia Plant Physiol. 125: 615-626.

Oh, S. A., Lee, S. Y., Chung, H. K., Lee, Ch., H. y Nam, H. G., 1996. A senescence associated gene of Arabodopsis thaliana is distinctively regulated during natural and artifiacially induced leaf senescence. Plant Mol. Biol. 30: 739-754. 
Oh, S.A., Park, J. H., Lee, G. I., Paek, K. H., Park, S. K. y Nam, H. G., 1997. Identification of three genetic loci controlling leaf senescence in Arabidopsis thaliana. Plant J. 12: 527-535.

Okamoto, T. y Minamikawa, T., 1999. Molecular cloning and characterization of Vinga mungo processing enzyme (VmPE-1), and asparaginyl endopeptidase possibly involved in post-translational processing of vacuolar cysteine endopeptidase (SH-EP). Plant Mol Biol.; 39: 63-73.

Okamoto, T., Shimada,T., Hara-Nishimura, I., Nishimura, M. y Minamikawa,T., 2003. C-Terminal KDEL Sequence of A KDEL-Tailed Cystein Proteinase (Sulfhydryl-Endopeptidase) Is Involved in Formation of KDEL Vesicle and in Efficient Vacuolar Transport of Sulfhydryl-Endopeptidase. Plant Physiol. 132: 1892-1900.

Otegui; M., Noh, Y. S., Martinez, D. E., Vila Petroff, M. G., Staehelin, L. A.,. Amasino, R. y Guiamét, J. J., 2005. Senescence-associated vacuoles with intense proteolyticactivity develop in leaves of Arabidopsis and soybean. Plant J. 41:831844.

Otsuga, D., DeGuzman, B., Prigge, M. J., Drews, G. N. y Clark, S. E., 2001. REVOLUTA regulates meristem initiation at lateral positions Plant J. 25: 223-236.

Packer, N., y Keatinge, L. 2001. Glycobiology and proteomics. En Proteomics. S.R. Pennington y M.J. Duna. (Eds.) pp 257-272. BIOS Scientific Publishers, Oxford. UK.

Palma, J. M., Sandalio, M. L., Corpas, J., Romero-Puertas, M., McCarthy, I. y del Río, A. 2002. Plant proteases, protein degradation, and oxidative stress: role of peroxisomes Plant Physiol. Biochem. 40 521-530.

Paris, N., Stanley, C. M., Jones, R. L. y Rogers, J. C., 1996. Plant cells contain two functionally distinct vacuolar compartments. Cell, 85, 563-572.

Park, J., Oh, S., Hee Kim, Y., Woo, H. R. y Nam, H. G., 1998. Differential expression of senescenceassociated mRNAs during leaf senescence induced by different senescence inducing factors in Arabidopsis. Plant Mol. Biol. 37: 445-454.

Park, H., Eggink, L. L., Roberson, R. W. y Hoober, J. K., 1999. Transfer of proteins from the chloroplast to vacuoles in Chlamydomonas reinhardtii (Chlorophyta): A pathway for degradation. J. Phycol. 35: 528-538. 
Parry, M. A. J., Andralojc, P. J., Khan, S., Lea, P. J. y Keys, A., J., 2002. Rubisco Activity: Effects of Drought Stress Annals of Bot. 89: 833-839

Peoples, M. B., Beilharz, V. C., Waters, S. P., Simpson, R. J. y Dalling, M. J., 1980. Nitrogen redistribution during grain growth in wheat (Triticum aestivum L.) II. Chloroplast senescence and the degradation of ribulose-1,5-bisphosphate carboxylase. Planta 149: 241-251

Perez-Amador, M. A., Abler, M. L. E., De Rocher, J., Thompson, D. M. y van Hoof, A., LeBrasseur, N. D., Lers, A. y Green, P. J., 2000. Identification of BFN1, a Bifunctional Nuclease Induced during Leaf and Stem Senescence in Arabidopsis. Plant Physiol. 122: 169-179.

Pic, E., Teyssendier de la Serve, B., Tardieu, F. y Turc, O., 2002. Leaf Senescence Induced by Mild Water Deficit Follows the Same Sequence of Macroscopic, Biochemical, and Molecular Events as Monocarpic Senescence in Pea. Plant Physiol, 128: 236-246.

Pinedo, M., Segarra, C. y Conde, R. D., 1993. Ocurrente of two endoproteinases in wheat leaf intercellular washing fluid. Physiol Plantarum 88: 287-293.

Pogson, B. J. y Morris, S. 2004. Postharvest senescence of vegetables and its regulation. En Plant Cell Death Process. L. Noodén (Ed.) pp 319-327. Elsevier Academic Press. MI. USA. Pontier, D., Gan, S., Amasino, R., Roby, D. y Lam, E., 1999. Markers for hypersensitive response and senescence show distinct patterns of expression. Plant Mol. Biol 39:1243 - 1255

Pružinská, A., Tanner, G., Aubry, S., Anders, I., Moser, S., Müller, T., Ongania, K. H., Kräutler, B., Youn, J., Liljegren, S., J. y Hörtensteiner, S., 2005. Chlorophyll Breakdown in Senescent Arabidopsis Leaves. Characterization of Chlorophyll Catabolites and of Chlorophyll Catabolic Enzymes Involved in the Degreening Reaction Plant Physiol. 139: 52-63

Radhamony, R. R., Mohan Prasad, A. y Srinivasan, R., 2005, T-DNA insertional mutagenesis in Arabidopsis: a tool for functional genomics. Electronic Journal of Biotechnology 8: 82-106.

Ratcliffe, O. J., Amaya, I., Vincent, C. A., Rothstein, S., Carpenter, R., Coen, E. S. y Bradley, D. J., 1998. A common mechanism controls the life cycle and architecture of plants. Development 125: 1609-1615.

Richter, S. y Lamppa, G. K., 1998. A chloroplast processing enzyme functions as the general stromal processing peptidase. Cell Biol. 95: 7463-7468. 
Robatzek, S. y Somssich, I. E., 2001. A new member of the Arabidopsis WRKY transcription factor family, AtWRKY6, is associated with both senescence- and defence-related processes Plant J. 28:123-133.

Robatzek, S. y Somssich, I. E., 2002. Targets of AtWRKY 6 regulation during plant senescence and pathogen defense. Genes and Develop. 16: 1139-1149,

Roberts, I. N., Fernandez Murray, P., Caputo, C. P., Passeron, S. y Barneix, A. J. 2003. Purification and characterization of a subtilisin-like serine protease induced during the senescence of wheat leaves. Physiol. Plantarum 118: 483-490.

Rogers, S. W., Burks, M. y Rogers, J. C., 2005. Monoclonal antibodies to barley aleurain and homologs fron other plants. Plant J. 11: 1359-1368.

Rojo, E., Zouhar, J., Carter, C., Kovaleva, V. y Raikhel, N.V., 2003. A unique mechanism for protein processing and degradation in Arabidopsis thaliana. Proc. Natl. Acad. Sci. USA 100: 7389-739.

Rousscaux, M., C., Hall. A. J. y Sánchez, R., A., 1996. Far-red enrichment and photosynthetically active radiation level influence leaf senescence in field-grown sunflower. Physiol Plant. 96: 217-224.

Rowan, B. A., Oldenburg, D. J. y Bendich, A., J., 2004. The demise of chloroplast DNA in Arabidopsis.Curr. Gen. 46: $176-181$

Safadi, F., Mykles, D. L., Reddy, A S. y N., 1997. Partial Purification and Characterization of a Ca2/-Dependent Proteinase from Arabidopsis. Roots Archives of Biochem. Biophys. 348: 143-151.

Sakakibara, H., 2003. Nitrate-specific and cytokinin-mediated nitrogen signaling pathways in plants. J Plant Res. 116: 253-257.

Satoh, H., Nakayama, K. y Okada, M., 1998. Molecular Cloning and Functional Expression of a Water-soluble Chlorophyll Protein, a Putative Carrier of Chlorophyll Molecules in Cauliflower. Biol. Chem. 273: 30568-30575.

Schaller A. y Ryan, C. A., 1994. Identification of a 50-kDa systemin-binding protein in tomato plasma membranes having Kex2p-like properties (proteinase inhibitors/plant defense/turin/signal transduction/plant plasma membranes) Proc. Natl. Acad. Sci. USA 91:11802-11806.

Segarra, C. I., Casalongué, C. A., Pinedo, M. L., Ronchi, V. P. y Conde, R D., 2003. A germin-like protein of wheat leaf apoplast inhibits serine porteases. J. Exp: Bot. 54: $1335-1341$. 
Shevchenko, A., Wilm, M., Vorm, O. y Mann, M., 1996. Mass Spectrometric Sequencing of Proteins from Silver-Stained Polyacrylamide Gels. Anal. Chem. 68: 850-858.

Schiltz, S., Gallardo, K., Huart, M., Negroni, L., Sommerer, N., y Burstin, J., 2004. Proteome Reference Maps of Vegetative Tissues in Pea. An Investigation of Nitrogen Mobilization from Leaves during Seed Filling. Plant Physiol. 135: 22412260.

Schmid, M., Simpson, D., Sarioglu, H., Lottspeich, F. y Gietl, C. 2001. The ricinosomes of senescing plant tissue bud from the endoplasmic reticulum Proc. Natl. Acad. Sci. USA 9: 5353-5358.

Schubert, M., Petersson, U. A., Haas, B. J., Funk, Ch., Schroder, W. P. y Kieselbach, T. 2002. Proteome map of the Chloroplast lumen of Arabidopsis thaliana. J. Biol. Chem. 277: 8354-8365.

Schultz, E. A. y Haughn, G. W., 1991. LEAFY, a Homeotic Gene That Regulates lnflorescence Development in Arabidopsis Plant Cell, 3: 771 -781.

Siezen, R. J. y Leunissen, J. A. M., 1997. Subtilases: The superfamily of subtilisinlike serine proteases Protein Sci. 6: 501-523.

Simões, R. y Faro, C., 2004. Structure and function of plant aspartic proteinases. Eur. J. Biochem. 271, 2067-2075.

Sjögren, L., MacDonald, L., Sutinen, S. y Clarke, A. K., 2004. Inactivation of the clpC1 Gene Encoding a Chloroplast Hsp100 Molecular Chaperone Causes Growth Retardation, Leaf Chlorosis, Lower Photosynthetic Activity, and a Specific Reduction in Photosystem Content. Plant Physiol. 136: 4114-4126.

Smith, A., Kingston-Smith, H., Bollard, A. y Minchin, F., 2005. Stress-induced changes in protease composition are determined by nitrogen supply in nonnodulating white clover. J of Exp. Bot. 56: 745-753.

Solomon, M., Belenghi, B., Dellorme, M., Menachem, E. y Levine, A., 1999. The involment of cisteine proteasas and protease inhibitor genes in the regulation of progarmed cell death in plants. Plant Cell 11: 431-443.

Sorefan, K., Booker, J. y Haurogne, K., 2003. MAX4 and RMS1 are orthologous dioxygenase-like genes that regulate shoot branching in Arabidopsis and pea. Genes Dev. 17:1469-1474. 
Sorin $^{a}$, C., Bussell, J. D., Camus, I., Ljung, K., Kowalczyk, M., Geiss, G., McKhann, H., Garcion, Ch., Vaucheret, H., Sandberg,G. y Bellini,C., 2005 Auxin and Light Control of Adventitious Rooting in Arabidopsis Require ARGONAUTE1. Plant Cell 17:1343-1359

Sorin ${ }^{\mathrm{b}}$, C., Negroni, L., Balliau, T., Corti, H., Jacquemont, M.P., Davanture, M., Sabdberg, G., Zivy,M. y Bellini,C., 2005. Proteomic Analysis of Different Mutant Genotypes of Arabidopsis Led to the Identification of 11 Proteins Correlating with Adventitious Root Development. Plant Physiol. 140: 349-365.

Srivalli, B., Bharti, S. y Khanna-Chopra, R., 2001. Vacuole cysteine protease and ribulose -1,4- biphosphate carbolylase/oxigenase deghradation during monocarpic senescence in cowpea leaves. Photosynthetica 39: 87-93.

Sterky, F., Bhalerao, R. R., Unneberg, P., Segerman, B., Nilsson, P., Brunner, A. M., Charbonnel-Campaa, L., Lindvall, J. J., Tandre, C., Strauss, S. H., Sundberg, B., Gustafsson, P., Uhle', M., Bhalerao, P. R., Nilsson, O., Sandberg, G., Karlsson, J., Lundeberg, K. y Jansson, S., 2004.. A Populus EST resource for plant functional genomics Proc. Natl. Acad. Sci. USA 101:13951-13956.

Stieger, P. A. y Feller, U., 1994. Senescence and protein remobilisation in leaves of maturing wheat plants grown on waterlogged soil. Plant and Soil: 166: 173 - 179

Sodmergen, S., Kawano, S., Tano, S. y Kuroiwa, T., 1991. Degradation of chloroplast DNA in second leaves of rice (Oryza sativa) before leaf yellowing. Protoplasma. $16089-98$.

Sokolenko, A., Altschmied, L. y Herrmann, R. G., 1997. Sodium dodecyl sulphatestable proteases in chloroplasts. Plant Physiol. 115: 827- 832.

Stirnberg, P., Chatfield, S.P. y Leyser, O., H. M., 1999. AXR1 Acts after Lateral Bud Formation to Inhibit Lateral Bud Growth in Arabidopsis. Plant Physiol. 121: 839847.

Stirnberg, P., van de Sande, K. y Leyser, O. H. M., 2002. MAX1 and MAX2 control shoot branching in Arabidopsis. Development 129: 1131-1141.

Sugawara, H., Shibuya, K., Yoshioka, T., Hashiba, T. y Satoh, Sh. 2002. Is a cysteine proteinase inhibitor involved in the regulation of petal wilting in senesceng carnation (Dianthus caryophyllus L.) flowers? J. Exp. Bot. 53: 407- 413

Swanson, S., Bethke, P. y Jones, R., 1998 Barley Aleurone Cells Contain Two Types of Vacuoles:Characterization of Lytic Organelles by Use of Fluorescent Probes. Plant Cell, 10: 685-698. 
Takamiya, K., Tsuchiya, T. y Ohta, H., 2000. Degradation pathway(s) of chlorophyll: what has gene cloning revealed? Trends in Plant Sci. 5: 1360-1385.

Tambussi, E. A, Bartoli, C. G., Beltrano, J., Guiamét, J. J.y Araus, J. L., 2000. Oxidative damage to thylakoid proteins in water-stressed leaves of wheat (Triticum aestivum). Physiol Plantarum 108, 398-404.

Tamura, K., Shimada, T., Ono, E., Tanaka, Y., Nagatani, A., Higashi, S., Watanabe, M., Nishimura, M. y Hara-Nishimura, I., 2003. Why green fluorescent fusion proteins have not been observed in the vacuoles of higher plants. Plant J. 35, 545555.

Tamura, K., Yamada, K., Shimada, T. y Hara-Nishimura, I., 2004. Endoplasmic reticulum-resident proteins are constitutively transported to vacuoles for degradation. Plant J. 39: 393-402.

Tanaka, H., Onouchi, H., Kondo, M., Hara-Nishimura, I., Nishimura, M., Machida,Ch. y Machida, Y., 2001. A subtilisin-like serine protease is required for epidermal surface formation in Arabidopsis embryos and juvenile plants Development 128: 4681-4689.

Tantikanjana, T., Yong, J. W. H., Letham, S., Griffith, M., Hussain, M., Ljung, K., Sandberg, G. y Sundaresan, V., 2001. Control of axillary bud initiation and shoot architecture in Arabidopsis through the SUPERSHOOT gene Genes \& Develop. 15:1577-1588.

Thomas, H., Ougham, H. J., Wagstaff, C. y Stead, A. D., 2003. Defining senescence and death. $J$ Exp. Bot. 54: 1127-1132.

Thompson, A. y Vierstra R. D., 2005. Autophagic recycling: lessons from yeast help define the process in plants. Curr. Opin. Plant Biol. 8:165-173

Tornero, P., Conejero, V. y Vera, P., 1996. Primary structure and expression of a pathogen-induced protease (PR-P69) in tomato plants: Similarity of functional domains to subtilisin-like endoproteases Proc. Natl. Acad. Sci. USA 93: 6332-6337.

Toyooka, K., Okamoto, T. y Minamikawa, T., 2001. Cotyledon cells of Vigna mungo seedlings use at least two distinct autophagic machineries for degradation of starch granules and cellular components. J. Cell Biol. 154, 973-982.

Trebitsh, T., Goldschmidt, E. E. y Riov, J., 1993. Ethylene Induces de novo Synthesis of Chlorophyllase, a Chlorophyll Degrading Enzyme, in Citrus Fruit Peel Proc. Natl. Acad. Sci. USA 90: 9441-9445. 
Tsuchiya, T.,Ohta, H., Okawa, K., Iwamatsu, A., Shimada, H., Masuda, T. y Takamiya, K., 1999. Cloning of chlorophyllase, the key enzyme in chlorophyll degradation: Finding of a lipase motif and the induction by methyl jasmonate. Proc. Natl. Acad. Sci. USA 96: 15362-15367.

Turnbull, C. G. N., Booker, J. P. y Leyser, O. H. M., 2002. Micrografting techniques for testing long-distance signalling in Arabidopsis. Plant J. 32: 255-262.

van der Hoorn, .R., Leeuwenburgh, M. A., Bogyo, M., Joosten, A. J. y Peck, S., 2004. Activity Profiling of Papain-Like Cysteine Proteases in Plants. Plant Physiol. 135: $1170-1178$.

van Doorn, W. G. y Woltering, E. J., 2004. Senescence and programmed cell death: substance or semantics? J. Exp. Bot. 55: 2147-2153.

Vierstra, R. D., 2003. The ubiquitin/26S proteasome pathway, the complex last chapter in the life of many plant proteins Trends in Plant Sci.8: 1360- 1385.

Von Groll, U., Berger, D. y Altmann, T., 2002. The Subtilisin-Like Serine Protease SDD1 Mediate Cell-to-Cell Signaling during Arabidopsis Stomatal Development Plant Cell, 14: 1527-1539.

Wagstaff, C., Leverentz, M. K., Griffiths, G., Thomas, B., Chanasut, U., Stead, A. D. y Rogers, H. J., 2002. Cysteine protease gene expression and proteolytic activity during senescence of Alstroemeria petals. J Exp Bot 367: 233-240.

Wardley, T. M., Bhalla, P. L. y Dalling, M. G., 1984. Changes in the Number and Composition of Chloroplasts during Senescence of Mesophyll Cells of Attached and Detached Primary Leaves of Wheat (Triticum aestivum L.). Plant Physiol. 75, 421-424.

Watanabe, M., Tanaka, H., Watanabe, D., Machida, Ch. y Machida, Y., 2004. The ACR4 receptor-like kinase is required for surface formation of epidermis-related tissues in Arabidopsis thaliana Plant J. 39: 298-308.

Weaver, L. M., Gan, S., Quirino, B. y Amasino, R. M., 1998. A comparison of the expression patterns of several senescence-associated genes in response to stress and hormone treatment. Plant Mol. Biol. 37: 455-469.

Weaver, M., Froehlich, J. E. y Amasino, R. M., 1999. Chloroplast-Targeted ERD1 Protein Declines but Its mRNA Increases during Senescence in Arabidopsis L. Plant Physiol. 119: 1209 -1216. 
Weaver, L. M. y Amasino, R. M., 2001. Senescence Is Induced in Individually Darkened Arabidopsis Leaves, but Inhibited in Whole Darkened Plants1 Plant Physiol. 127: 876-886.

Westphal, S., Soll, J. y Vothknecht, U. C., 2001. A vesicle transport system inside chloroplasts. FEBS Letters 506: 257-261.

Whitelegge, J. P., 2003. Thylakoid membrane proteomics. Photosynth Res.78: 265-7.

Wiederanders, B., Kaulmann, G., y Schilling, K., 2003. Functions of propeptide parts in cysteine proteases. Curr. Opin. \& Peptide Sci. 4: 309-326.

Wilson, K. A., McManus, M. T., Gordon, M. E. y Jordan, W., 2002. The proteomics of senescence in leaves of white clover, Trifolium repens (L.) Proteomics 2: 1114 1122.

Wingler, A., von Schaewen, A., Leegood, R., C., Lea, P., J. y Quick, W. P., 1998. Regulation of Leaf Senescence by Cytokinin, Sugars, and Light. Effects on NADHDependent Hydroxypyruvate Reductase. Plant Physiol. 116: 329-335.

Wingler, A., Brownhill, E. y Pourtau, N., 2005. .Mechanisms of the light-dependent induction of cell death in tobacco plants with delayed senescence. J. Exp. Bot. 56: 2897-2905.

Woo, H. R., Chung, K. M., Park, J. H., Oh, S. L., Ahn, T., Hong, S. H., Jang, S. K. y Nam, H. G., 2001. ORE9, an F-Box Protein That Regulates Leaf Senescence in Arabidopsis. Plant Cell, 13: 1779-1790.

Woo, H. R., Goh, Ch. H., Park, J. H., Teyssendier de la Serve, B., Kim, J. H., Park, Y. y Nam, H. G., 2002. Extended leaf longevity in the ore4-1 mutant of Arabidopsis with a reduced expression of a plastid ribosomal protein gene. Plant J. 31: 331-340.

Wrobel, R. y Jones, B. 1992. Appearence of endoproteolytic enzimes during the germination of Barley, Plant Phys 100: 1508-1516.

Xu, Ch., Fan, J., Riekholf, W., Froehlinch, J. E. y Benning, Ch., 2003. A permeaselike protein involved in ER to thylakoid lipid transfer in Arabidopsis. EMBO Journal 22: $2370 \pm 2379$.

Yamada, K., Matsushima, R., Nishimura, M. y Hara-Nishimura, I., 2001. A Slow Maturation of a Cysteine Protease with a Granulin Domain in the Vacuoles of Senescing Arabidopsis Leaves. Plant Physiol. 127: 1626-1634. 
Yamagata, H., Masuzawa, T., Nagaoka, Y., Ohnishi, T. y Iwasaki, T., 1994. Cucumisin, a Serine Protease from Melon Fruits, Shares Structural Homology with Subtilisin and Is Generated from a Large Precursor. J. Biochem. 269: 32725-32731.

Yamauchi, Y., Sugimoto, T., Sueyoshi, K., Oji, Y., Tanaka, K., 2002. Appearance of endopeptidases during the senescence of cucumber leaves. Plant Sci. 162: 615- 619 .

Yang, D. H., Webster, J., Adam, Z., Lindahl, M. y Andersson, B., 1998. Induction of Acclimative Proteolysis of the Light-Harvesting Chlorophyll $a / b$ Protein of Photosystem II in Response to Elevated Light Intensities. Plant Physiol. 118: 827834

Yoshida, T. y Minamikawa, T., 1996. Successive Amino-Terminal Proteolysis of the Large Subunit of Ribulose 1,5-bisphosphate Carboxylase/Oxygenase by Vacuolar Enzymes from French Bean Leaves. Eur. J. Biochem. 238: 317- 324.

Yoshida, S., Ito, M., Nishida, I. y Watanabe, A., 2002. Identification of a novel gene HYS1/CPR5 that has a repressive role in the induction of leaf senescence and pathogen-defence responses in Arabidopsis thaliana. Plant J. 29: 427-437.

Yoshida, S., 2003. Molecular regulation of leaf senescence. Curr. Opin. in Plant Biol. 6: 79-84.

Zagdansza, B. y Wisnieewski, K. 1996. Endoproteinase activities in wheta upon water deficit. Acta Bioch. Polonia. 43: 515-520.

Zavaleta- Mancera, H. A., Frankln, K. A., Ougham, H. J., Thomas, H. y Scout, I. M., 1999. Reappearance of NADPH- protochlorophyllide oxidoreductase and light harvesting chlorophyll a/a -bindingprotein. J. Exp. Bot. 50: 1677-1682.

Zavaleta- Mancera, H. A., Thomas, B. J., Thomas, H., y Scout, I. M. 1999. Redifferentiation of plastids. J. Exp. Bot. 50: 1683-1689.

Żelisko, A., Garcia-Lorenzo, M., Jackowski, G., Jansson, S. y Funk, Ch., 2005. AtFtsH6 is involved in the degradation of thelight-harvesting complex II during high-light acclimation and senescence Proc. Natl. Acad. Sci. USA 102: 1369913704.

Zhang, L., Rui, Q. y Lang Lai, X., 2005. Degradation of the large subunit of Ribulose-1,5-biphosphate carboxylase/oxigenase in wheat leaves. $J$ Integrative Plant. Biol. 47: 60-66. 
Zhao, Ch., Johnson, B. J., Kositsup, B. y Beers, E. P., 2000. Exploiting Secondary Growth in Arabidopsis Construction of Xylem and Bark cDNA Libraries and Cloning of Three Xylem Endopeptidases Plant Physiol. 123: 1185-1196. 